\title{
MICROBIAL FIELD PILOT STUDY
}

\author{
By \\ R. M. Knapp \\ M. J. McInerney \\ D. E. Menzie \\ J. L. Chisholm
}

November 1990

Work Performed Under Contract No. DE-FG22-89BC14246

Prepared for

U.S. Department of Energy

Assistant Secretary for Fossil Energy

Edith Allison, Project Manager

Bartlesville Project Office

P.O. Box 1398

Bartlesville, OK 74005

Prepared by

University of Oklahoma

Norman, OK 73019 


\section{TABLE OF CONTENTS}

Page

LIST OF TABLES $\ldots \ldots \ldots \ldots \ldots \ldots \ldots \ldots \ldots \ldots \ldots$

LIST OF FIGURES $\ldots \ldots \ldots \ldots \ldots \ldots \ldots \ldots \ldots \ldots$. . . . . . . . . .

ABSTRACT $\ldots \ldots \ldots \ldots \ldots \ldots \ldots \ldots \ldots$

1. ECOLOGY OF THE RESERVOIR . . . . . . . . . . . . . . 1

1.1 Experimental Procedure $\ldots \ldots \ldots \ldots \ldots \ldots \ldots$

1.2 Results . . . . . . . . . . . . . . . . . . . 2

1.3 Discussion . . . . . . . . . . . . . . .

1.4 Conclusions . . . . . . . . . . . . . . . . . . . . .

References . . . . . . . . . . . . . . . . . . 5

2. SURFACE FACILITIES DESIGN $\ldots \ldots \ldots \ldots \ldots$

3. THE SOUTHEAST VASSAR VERTZ SAND UNIT (SEVVSU) . . . . . . 22

References ......................... 26

4. CORE FLOOD EXPERIMENTS . . . . . . . . . . . . . . . . . . 30

4.1 Introduction . . . . . . . . . . . . . . . . . . . . . . . . . .

4.2 Mechanisms of Microbial Enhanced Oil Recovery . . . . . . . . . . .30

4.3 Experimental Analysis . . . . . . . . . . . . . . . . 36

4.4 Core Experiment . . . . . . . . . . . . . . . . . . . . . . . . . . . . . . . .

4.5 Discussion of Results . . . . . . . . . . . . . . . . . . . . 42

4.6 Conclusions . . . . . . . . . . . . . . . . . . . . . .44

References . . . . . . . . . . . . . . . . . . . . . 46

5. BACTERIAL MOVEMENT AND ACTIVITY IN POROUS

SUBSURFACE FORMATIONS . . . . . . . . . . . . . 56

5.1 Introduction . . . . . . . . . . . . . . . . . . . . . .

5.2 Materials and Methods . . . . . . . . . . . . . . . 57

5.3 Results . . . . . . . . . . . . . . . . . . . . .58

5.4 Discussion . . . . . . . . . . . . . . . . . . .60

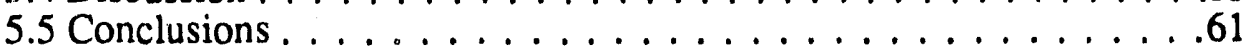

References . . . . . . . . . . . . . . . . . . . 62

6. MATHEMATICAL MODELLING OF THE MEOR PROCESS . . . . . . . 68

6.1 Introduction . . . . . . . . . . . . . . . . . . . . .

6.2 Microbial Activities . . . . . . . . . . . . . . . . . . . . . . 69

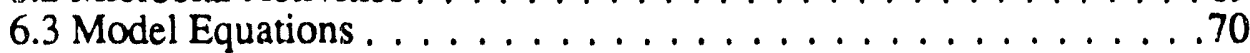

6.4 Simplification and Specification . . . . . . . . . . . . . . .77

6.5 Numerical Solutions . . . . . . . . . . . . . . . . . . . . .80

6.6 Application . . . . . . . . . . . . . . . . . . . 82

6.7 Conclusions . . . . . . . . . . . . . . . . . . . .83

References . . . . . . . . . . . . . . . . . . . . . . . .84 


\section{LIST OF TABLES}

Table $\quad \underline{\text { Page }}$

1.1 Chemical composition of Molasses-Nitrate medium . . . . . . . . . . . 6

1.2 Chemical composition of Tanner's mineral solution . . . . . . . . . . . . . 6

1.3 Chemical composition of Tanner's metal solution . . . . . . . . . . . . .

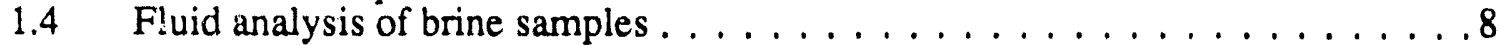

1.5 Concentrations of sulfate and sulfide in brines . . . . . . . . . . . . .9

1.6 Growth in brine samples using different nutrient additions . . . . . . . . . . 10

1.7 Numbers of Molasses nitrate-using bacteria in brine samples . . . . . . . . . . . 11

1.8 Numbers of sulfate-reducing bacteria in brine samples . . . . . . . . . . . 11

1.9 Physiological properties of halnphilic isolates . . . . . . . . . . . 12

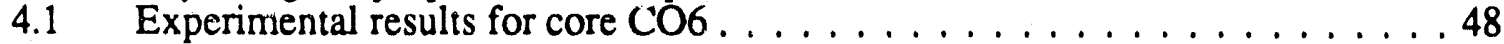

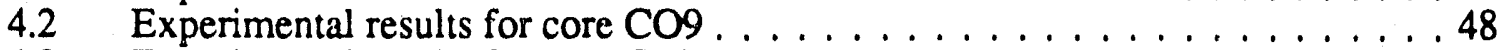

4.3 Experimental results for core $\mathrm{C} 10 \ldots \ldots \ldots \ldots$

4.4 Experimental results for core $c 11 \ldots \ldots \ldots \ldots$

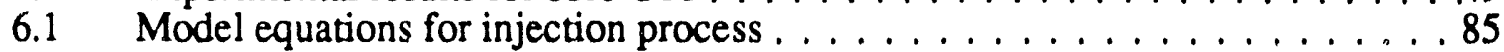

6.2 Model equations for incubation process $\ldots \ldots \ldots \ldots \ldots$

6.3 Model equations for continued-injection process . . . . . . . . . . . . .87

6.4 Batch-fermentation two-substrate model . . . . . . . . . . . . . . 88

6.5 Stoichiometric parameters . . . . . . . . . . . . . . . . 89

6.6 Kinetic parameters for batch fermentation . . . . . . . . . . . . . . .90

6.7 Experimental results from batch fermentation . . . . . . . . . . . . .91

6.8 Simulation Response to batch fermentation . . . . . . . . . . . . . . .91 


\section{LIST OF FIGURES}

Figure $\quad \underline{\text { Page }}$

2.1 Injection well facility $\ldots \ldots \ldots \ldots \ldots \ldots \ldots \ldots \ldots$

2.2 Plan for injection well facility installation $\ldots \ldots \ldots \ldots \ldots$

2.3 Procedure for nutrient treatment injection . . . . . . . . . . . . . 18

2.4 Plan for production well facility installation . . . . . . . . . . . . . 19

2.5 Gathering system design . . . . . . . . . . . . . . . . 20

2.6 Separator and tank batteries . . . . . . . . . . . . . . . . . . . 21

3.1 Oklahoma geological regions (after Oklahoma Geological Survey, 1972) . . . 27

3.2 Net thickness map of Southeast Vassar Vertz Sand Unit (SEVVSU) . . . . . . . 28

3.3 Grid block diagram for fine grid simulation with net thickness map of south SEVVSU . . . . . . . . . . . . . . . . . . . . . . . 29

4.1 Capillary desaturation curve (after Stalkup) . . . . . . . . . . . . . . . . . 50

4.2 Experimental set-up . . . . . . . . . . . . . . . . . . .51

4.3 Effect of nutrient treatments on PRF, cumulative oil

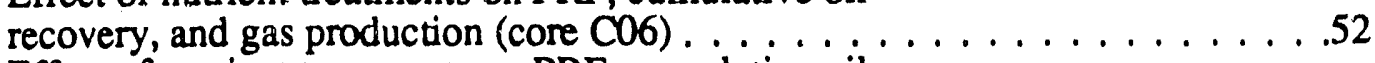

4.4 Effect of nutrient treatments on PRF, cumulative oil recovery, and gas production (core CO9) . . . . . . . . . . . . . . 53

4.5 Effect of nutrient treatments on PRF, cumulative oil recovery, and gas production (core $\mathrm{C} 10) \ldots \ldots \ldots \ldots \ldots \ldots$

4.6 Effect of nutrient treatments on PRF, cumulative oil

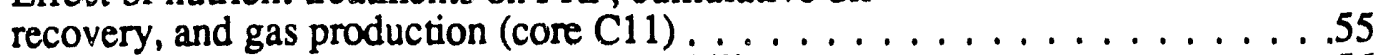

4.7 Wetting and non-wetting relative permeability curves . . . . . . . . . . . . 56

5.1 Growth of $E$. coli RW262 in nutrient saturated, sand-packed cores . . . . . . . . . . . . . . . . . . . . . . . 63

5.2 Change in galactose (open square) and acetate (closed square) in nutrient-saturated, sand-packed cores . . . . . . . . . . . . . . . . 64

5.3 Propagation of cells through sand-packed cores . . . . . . . . . . 65

5.4 Change in acetate concentration with time in different sections of the core . . . . . . . . . . . . . . . . . 66

5.5 Change in galactose concentration with time in different sections of the core . . . . . . . . . . . . . . . . . . 67

6.1 Consumption of galactose during batch fermentation . . . . . . . . . . 92

6.2 Consumption of nitrate during batch fermentation . . . . . . . . . . . 93

6.3 Growth of biomass during batch fermentation . . . . . . . . . . . . . . . 94

6.4 Production of acetate during batch fermentation . . . . . . . . . . . .95

6.5 Production of $\mathrm{N}_{2}$ during batch fermentation . . . . . . . . . . . . 96 


\begin{abstract}
This report covers progress made during the first year of the Microbial Field Pilot Study project. Information on reservoir acology and characterization, facility and treatment design, core experiments, bacterial mobility, and mathematical modeling are addressed in this report.

To facilitate an understanding of the ecology of the target reservoir analyses of the fluids which support bacteriological growth and the microbiology of the reservoir were performed. The results of the water analysis show significant sulfide concentrations. One uniquely shaped motile bacteria was identified and isolated. Five previous isolates were characterized. Various substrates were compared for their ability to promote bacterial growth in brine samples.
\end{abstract}

A preliminary design of facilities for the operation of the field pilot test was prepared. In addition, procedures for facilities instillation and for injection treatments are described.

The Southeast Vassar Vertz Sand Unit (SEVVSU), the site of the proposed field pilot study, is described physically, historically, and geologically. The fields current status is presented and the ongoing reservoir simulation is discussed.

Core flood experiments conducted during the last year were used to help define possible mechanisms involved in microbial enhanced oil recovery. Two possible mechanisms, relative permeability effects and changes in the capillary number, are discussed and related to four Berea core experiments' results. The experiments were conducted at reservoir temperature using SEVVSU oil, brine, and bacteria. Based on relative permeability and capillary number studies by other investigators, it is concluded that these effects cannot account for all of the oil recovered from some cores.

The movement and activity of bacteria in porous media were investigated by monitoring the growth of bacteria in sandpack cores under no flow conditions. The rate of bacteria advancement through the cores was determined. It was possible to monitor the concentration of cells, substrate, and metabolic products as functions of both time and distance in some cores.

A mathematical model of the MEOR process has been developed. The model is a three phase, seven species, one dimensional model. Finite difference methods are used for solution. Advection terms in balance equations are represented with a third-order upwind differencing scheme to reduce numerical dispersion and oscillations. The model is applied to a batch fermentation example and demonstrates a good match with the experimental data. 


\section{ECOLOGY OF THE RESERVOIR}

\section{Introduction.}

A thorough understanding of the ecology of the reservoir is a key step in the implementation of a microbial enhanced oil recovery field pilot. It is critical that the chemical composition of reservoir brines be understood so that compatable organisms and nurrients can be selected. The aqueous phase represents the most important part of the reservoir, since it is in this phase that the nutrients required for growth and metabolism will be transported. The analyses of the fluids will provide baseline data needed to assess the sucess of the pilot.

\subsection{Experimental Procedure.}

\section{Sampling procedure:}

Brine was collected from different sites in the field. The sample sites include the source well, the pump manifold, and wells 1A-1, 1A-7, 1A-9, 7-2, 8-2 and, 8-3 respectively. All samples were taken using sterile techriques. All samples were analyzed within four hours for bacterial numbers. The brine samples were stored at $4^{0} \mathrm{C}$ until all analyses had been completed.

\section{Fluid analysis:}

Hardness, alkalinity, iron, phosphate, sulfate, sulfide, nitrate, nitrite analyses were performed using Hach chemical kits (Hach chemical Co. 1975). Total dry residues and suspended solids were determined using standard procedures (American Public Healih Association, 1985).

\section{Bacterial analysis:}

To determine the best nutrient source for the stimulation of indigenous microorganisms, brine samples were amended with various nutrient mixtures. Brine samples were dispensed into serum tubes which were closed with rubber bungs and crimp sealed. Where indicated, molasses, sucrose, glucose, and fructose were added to give a final concentration of $0.2 \%$ (wt/vol except for molasses which was added on a vol/vol basis). Ammonium nitrate and sodium sulfate were added to give a final concentration of $0.3 \%$ (wt/vol). Sodium lactate and sodium thiosulfate were added to give a final concentration of $0.1 \%$ (vol/vol) and $0.2 \%(\mathrm{wt} / \mathrm{vol})$, respectively. Unamended brine samples served as controls. All manipulations were done anaerobically. Tubes were incubated at $35^{\circ} \mathrm{C}$ and routinely checked microscopically and turbidimetrically for growth. Anaerobic 
molasses-nitrate using bacteria and sulfate-reducing bacteria were enumerated by three-tube most probable number method using a molasses-nitrate medium (Table 1.1) and A.PI-RST medium (Tanner el al. 1985), respectively.

\subsection{Results.}

\section{Water analysis:}

Chemical analysis of the brines collected from different sites is shown in Table 1.4. All brines were highly saline with total dry residues ranging from about $10 \%$, for the source well, to greater than $19 \%$ for the brines collected in the portion of the reservoir that was not waterflooded (well 1A-7). The brines contained high levels of divalent cations particularly calcium, ranging from 1.5 to $2.2 \%$. The alkalinity in most of the brine samples was also high, indicating that some carbonate was present. Little or no phosphate or nitrite was detected in the brine. However, iron and nitrate were detected. The small amounts of nitrate detected in the brines could have been due to interferences in chemical analysis. The $\mathrm{pH}$ of all the brines was close to neutral. Significant amounts of sulfate were detected in some brines (Table 1.5). Small amounts of sulfide were also detected in some wells, especially those in the waterflood region of the reservoir indicating a sulfate reducing activity (1.5).

\section{Bacterial analysis:}

Since previous studies showed the presence of indigenous microbial populations that were able to grow readily with simple nutrient additions (Knapp et al. 1989), it was important to determine which nutrient source would best stimulate microbial growth. In the present study brines from severa! wells were amended with different nutrient mixtures (Table 1.6). Results from these experiments show that molasses alone supported good growth of the indigenous populations. However, the addition of molasses toge:her with ammonium nitrate resulted in the largest increases in the growth of the indigenous microbial populations. In some brines, the addition of either glucose or sucrose with or without ammonium nitrate stimulated growth. The addition of a phosphate source and an additional nitrogen source to brines ammended with individual sugars did not stimulate microbial growth. Thus a complex nutrient source is required for optimal growth of the indigenous populations.

Since previous studies have shown the presence of sulfate reducing activity, brines from different sites were amended with acetate and lactate to detect the 
presence of sulfate-reducing bacteria. With the exception of brine from well 8-3, there was no evidence of any microbial growth. In the brine from well 8-3, addition of acetate and lactate stimulated growth. Microscopic examination of this brine led to the identification of an uniquely shaped microorganism. The microorganism was highly motile and varied in size from time to time. Studies are presently underway to characterize this microorganism. Enumeration studies showed that the concentration of anaerobic molasses-nitrate using bacteria were much lower than previously found (Table 1.7). Aerobic and anaerobic heterotrophic bacteria that could grow in plate count broth (Difco, Inc, Detroit, MI) with $15 \% \mathrm{NaCl}$ were not detected. The concentration of sulfate-reducing bacteria was also low (Table 1.8). Higher rumbers of sulfate-reducing bacteria were found in brine from the source well (Table 1.8). The relatively low concentrations of sulfate-reducing bacteria and molasses-nitrate using bacteria detected in the brines could have been a result of the biocide treatment which was initiated a few months earlier. Since the addition of lactate and acetate to the brines collected from the water flodded region of the reservoir did not stimulate the growth of sulfate-reducing bacteria this indicated that these brines lack an essential nutrient which is required for the growth of these bacteria.

Five of the most numerous anaerobic, heterotrophic bacterial isolates which were previously isolated were also characterized (Table 1.9). For convenience sake the isolates were designated TA,WA,QB,SA, AND TTL-30, respectively. All of the isolates were strictly anaerobic and obligately halophilic, requiring at least $9 \% \mathrm{NaCl}$ for growth. They used a variety of carbohydrate substrates such as glucose, sucrose, maltose, fructose, fucose, mannose, galactose, arabinose, trypticase, peptone, inulin, and yeast extract as energy sources and produceacetic acid and solvents. Some of the other substrates utilized by these isolates include; pyrogallic acid, lactic acid, formate, succinate glycerol, and glucosamine. These isolates grew well in a molasses-nitrate-mineral salts medium containing $15 \% \mathrm{NaCl}$ ( $w t / \mathrm{vol}$ ). Since all of these bacteria are obligately anaerobic and halophilic, they will not survive outside of the reservoir and do not pose a serious health risk.

\subsection{Discussion:}

An understanding of the microbial ecology of the reservoir is a key step for the development of a sucessful microbial enhanced oil recovery process. Brine 
analysis indicates that the reservoir is a highly saline environment. Previous analysis of brines from the reservoir have indicated the presence of microorganisms which require high concentrations of $\mathrm{NaCl}$ for growth. The bacteria use molasses and nitrate and form large amounts of gas and at times polymers. The present study shows that a molasses-ammonium nitrate nutrient mixture would best stimulate the growth of indigenous microorganisms in brines from Southeast Vassar Vertz Sand Unit reservoir. Since microbial populations already exist in the sub-surface, the introduction of organisms will not be necessary. Also, since the organisms isolated from the brines are halophilic and anaerobic, their accidental release into the environment will not create any environmental or health hazards since these bacteria will not grow in freshwater systems.

Jenneman et al (1986) reported that sulfide production can be inhibited by high concentrations of nitrate. Thus, the problem of sulfate reduction due to high concentrations of sulfate detected in the reservoir can be controlled with the addition of nitrate.

\subsection{Conclusions:}

1. A molasses-ammonium nitrate nutrient mixture would best stimulate the growth of indigenous bacterial populations in Southeast Vassar Vertz Sand Unit reservoir.

2. The ability to utilize a fermentable carbohydrate and the halophilic nature of the isolated microorganisms make them a good choice for microbially enhanced oil recovery processes in hypersaline environments. 


\section{REFERENCES}

American Public Health Association, American Water Works association and Water Control Polution Control Federation: Standard Methods For the Examination of Water and Wastewater, Sixteenth Edition, American Public Health Association, Washington, DC (1985) 92-100, 856-859.

Hach Chemical Co.: Hach Water and Waste Water Analysis Procedure Manual 3rd Edition, Hach Chemical Co, Ames, IA (1975).

Jenneman, G.E., McInemey, M.J., and Knapp, R.M.: " Effect of Nitrate on Biogenic Sulfide Production," Appl. Environ. Microbiol. (June. 1986) 1205-1211.

Knapp, R. M., McInerney, M. J., and Menzie, D. E., Raiders, R.A.: "Microbial Field Pilot Study," Final report , DOE/BC/14084-6, National Technical Informational Services, Springfield,VA,(1989).

Raiders, R.A., Knapp, R.M., McInemey, M.J., and Menzie, D.E. : "Microbial Selective Plugging and Enhanced Oil Recovery,"J. Indust. Microbiol., (April.1989), 4, 215-230.

Tanner, R. S., Haack, T.K., Semet, R. F., and Greenley, D. E. : " A Mild Steel Tubular Flow System for Biofilm Monitoring, " Proceedings of the United Kingdom National Academy of Corrosion Engineers Corossion '85, Harrowgate, Uk (1985) 259-269. 

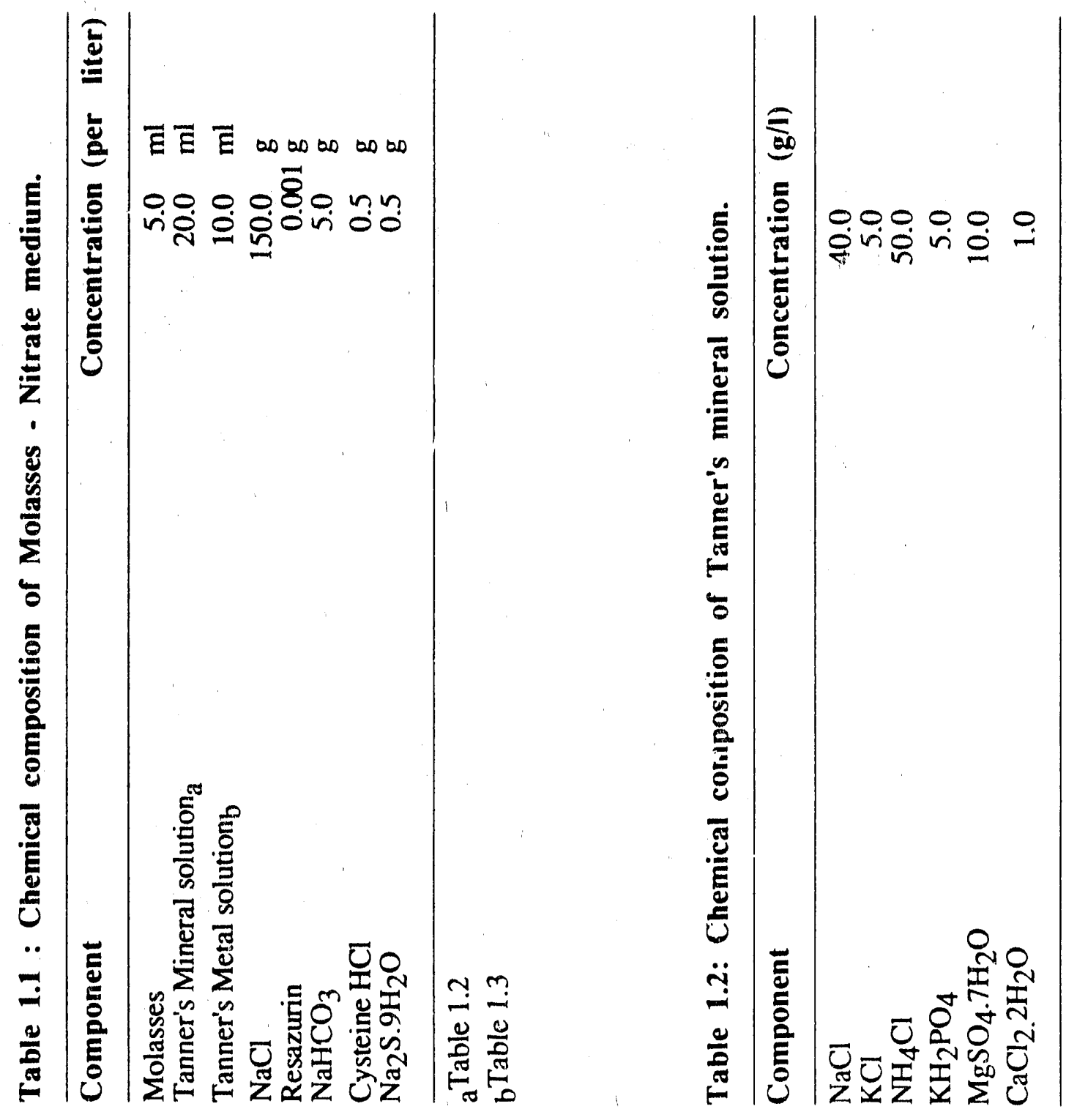


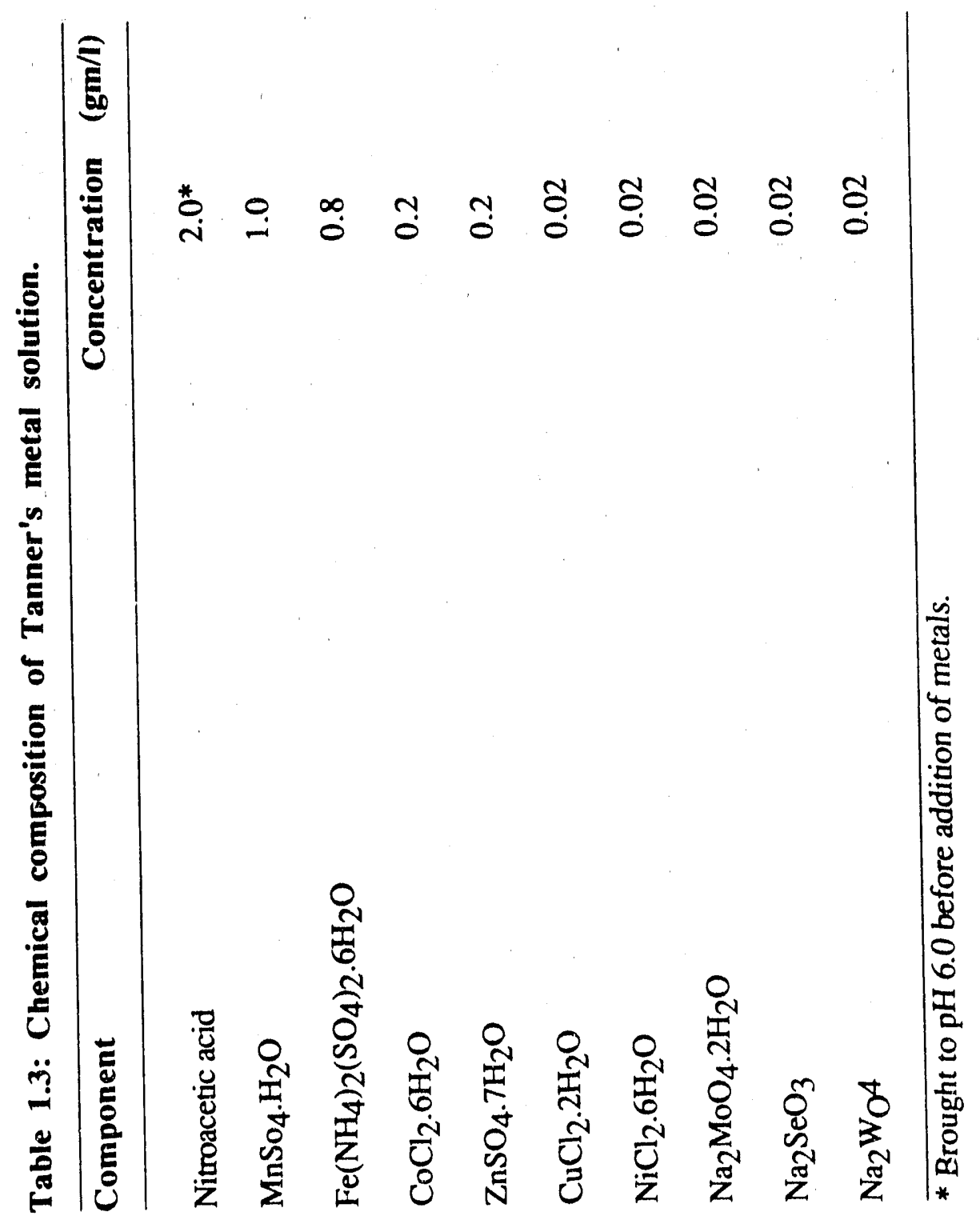




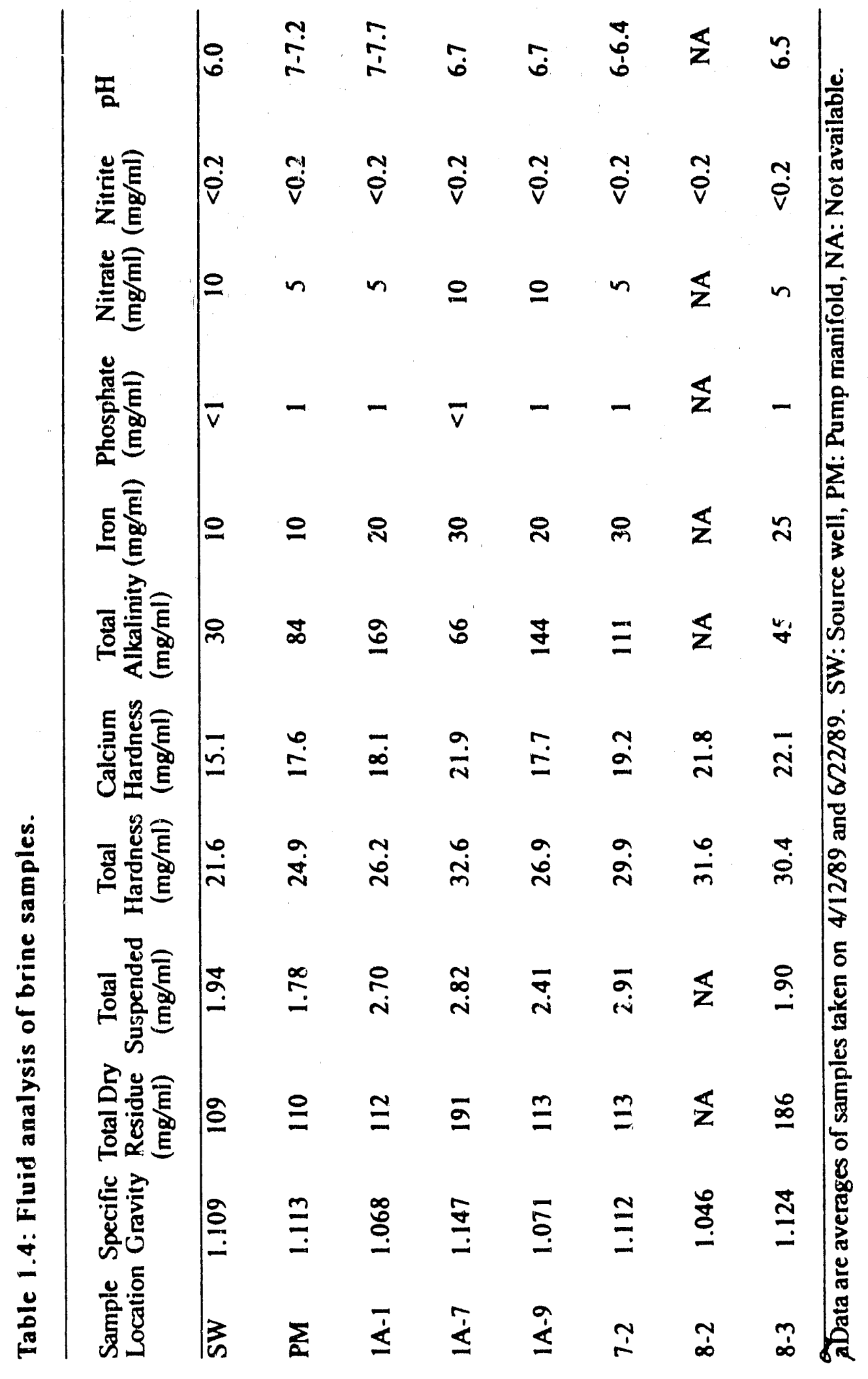




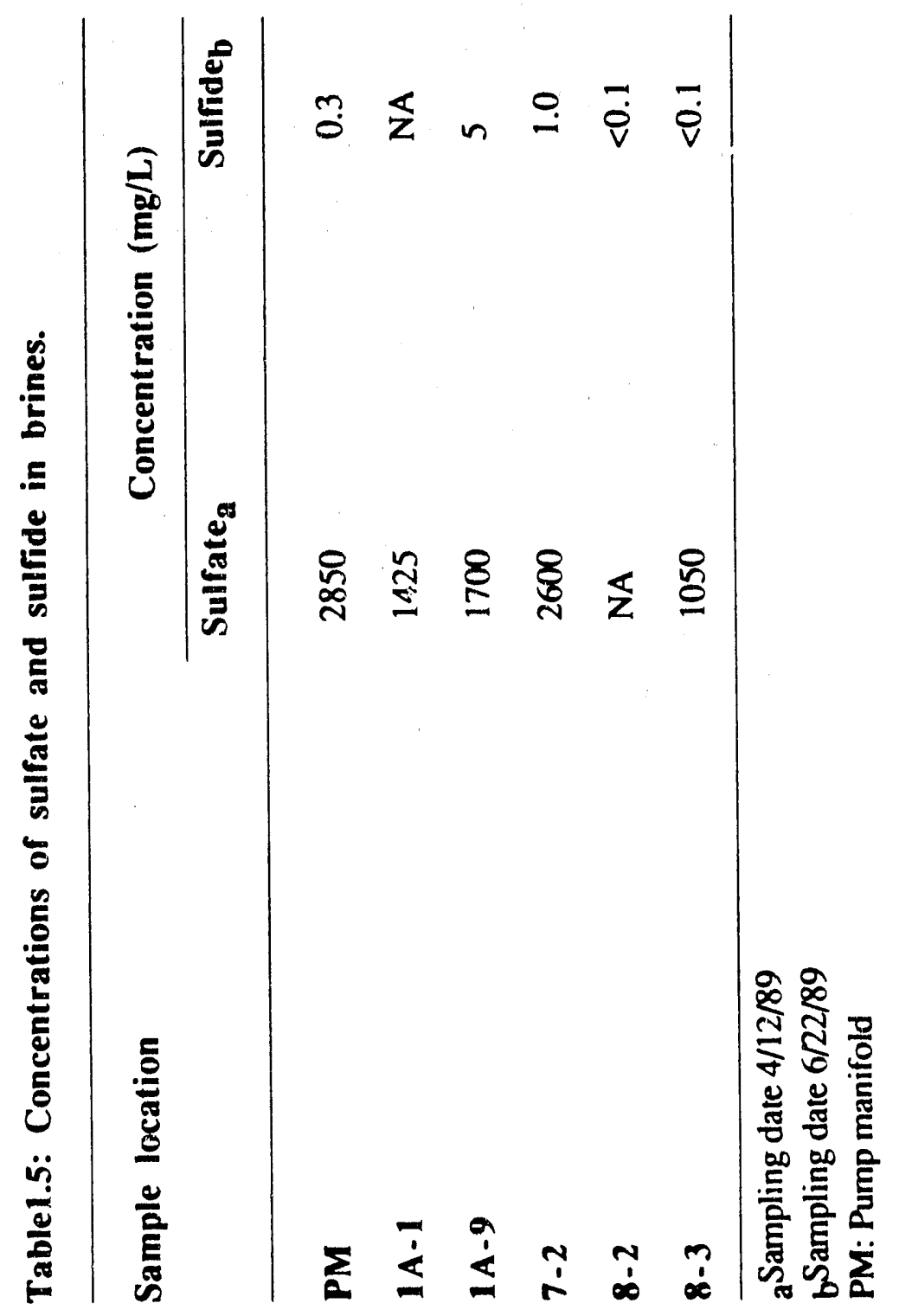




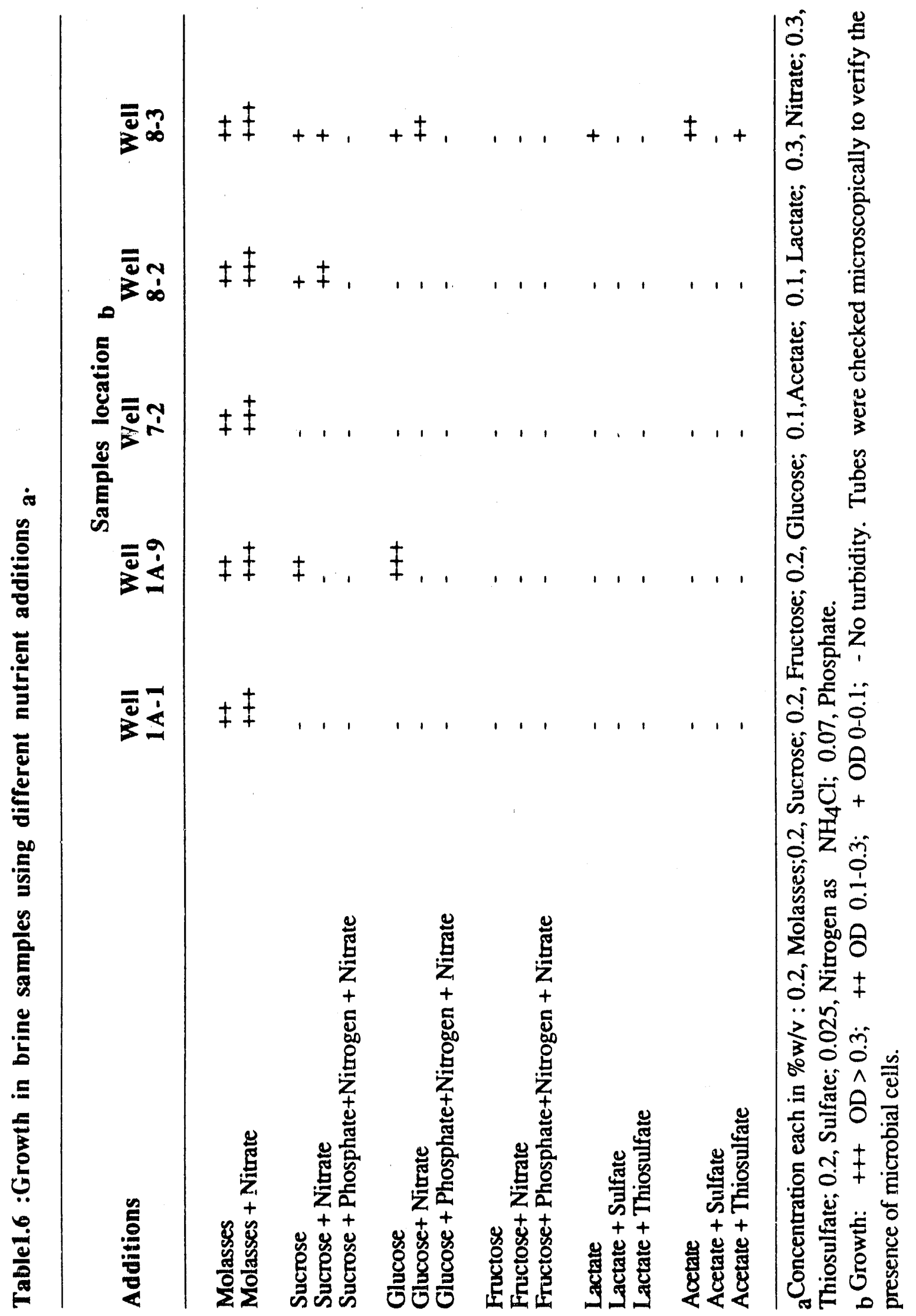



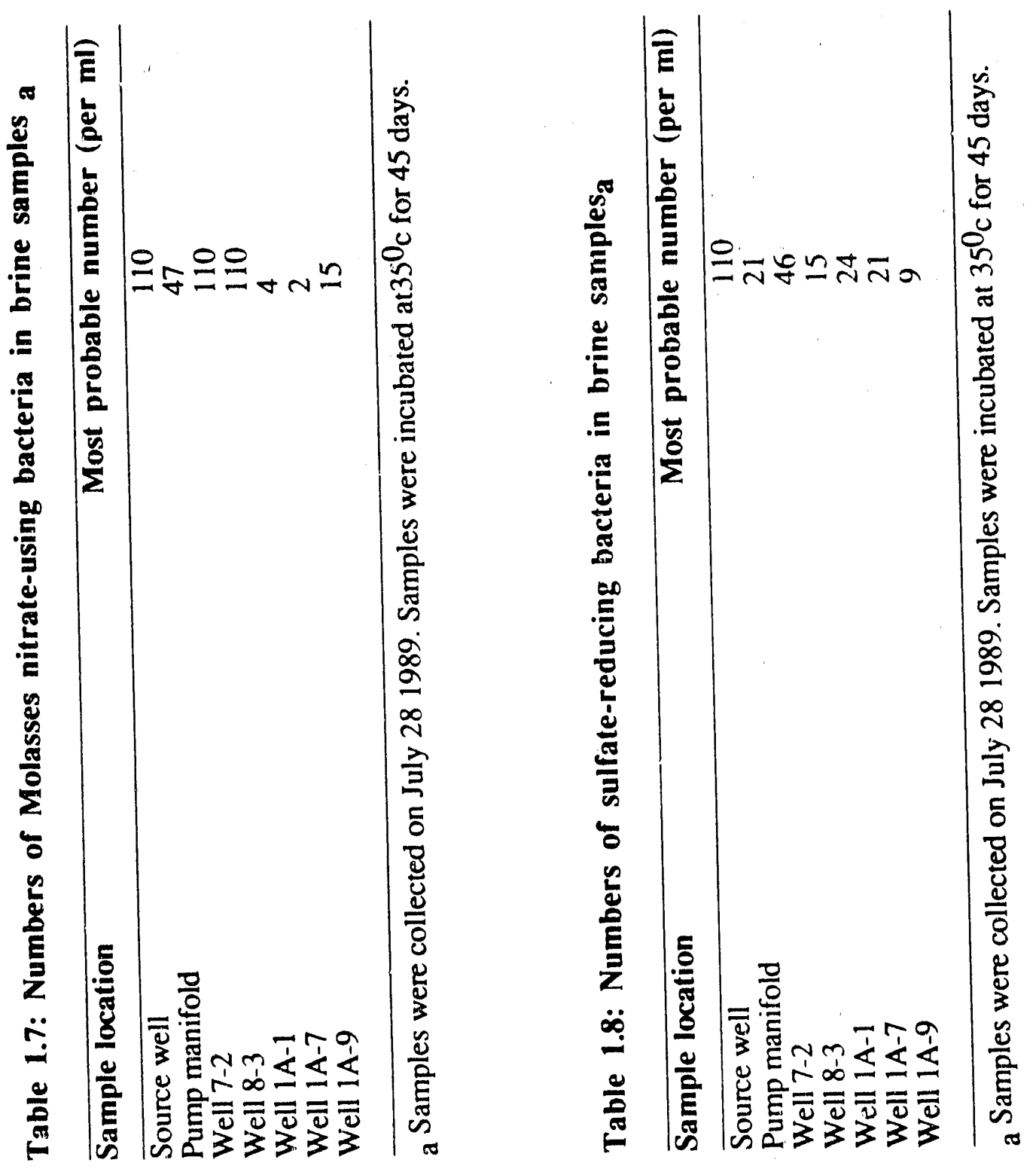


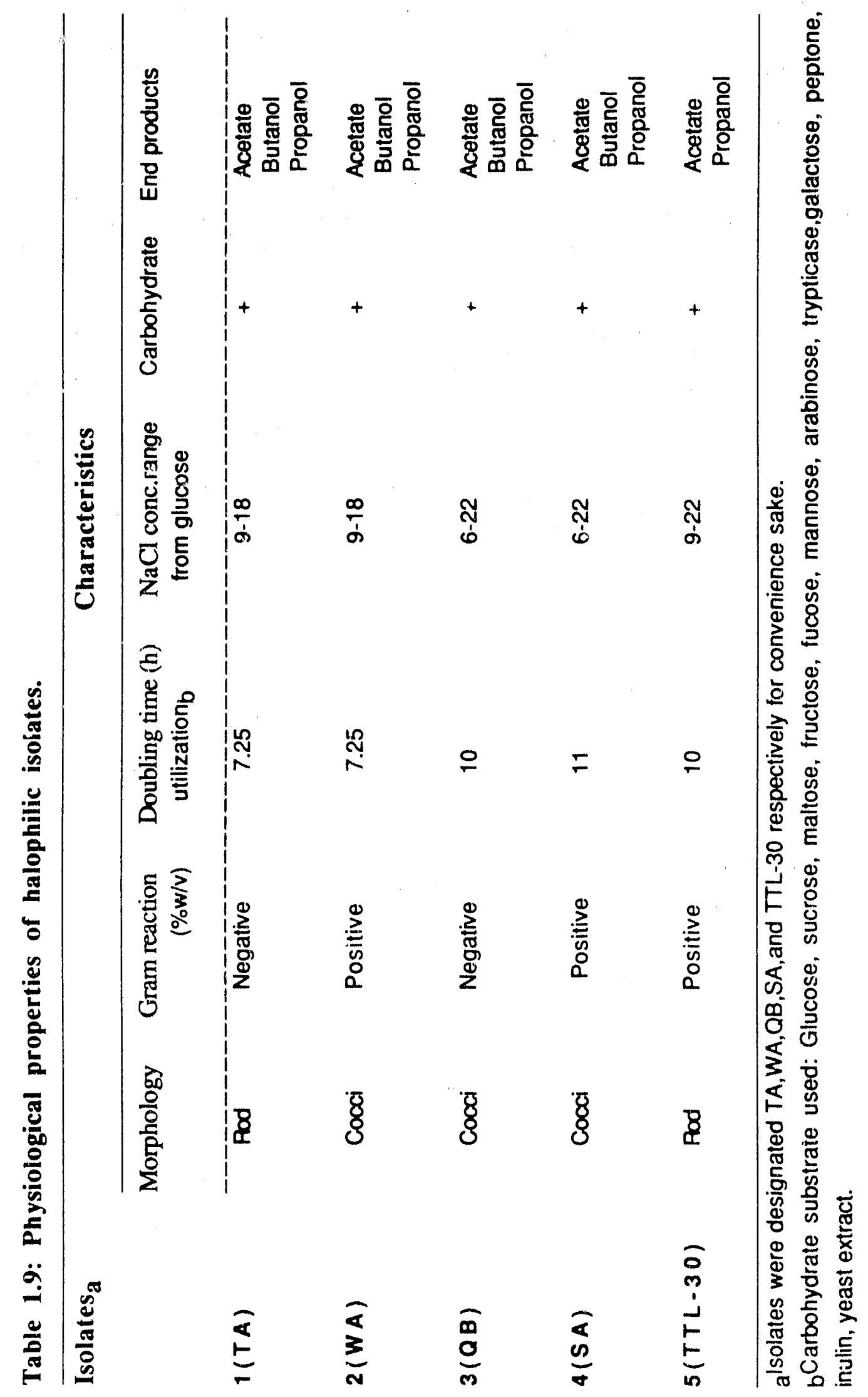




\section{Surface Facilities Design}

A preliminary design of the facilities for the operation of this field pilot has been developed. The surface facilities will mix the nutrient-brine injection slugs and inject these mixtures and subsequent brine slugs into the formation. Also, facilities will be installed to gather the produced fluids in a central location allowing their separation and storage.

The injection well (7-2) will have a packer run on a 2.5 in. tubing string set immediately above the perforations in the Vertz sandstone. No special completion is expected. No chemicals will be used to reduce or eliminate bacterial growth in the wellbore.

An overall plan of the injection well facility is presented in Figure 2-1. The Mesa triplex pump is the existing injection pump in the field. This pump will provide brine water for mixing nutrient slugs and provide for the injection of brine spacers between slugs of nutrient mixture. The hot oil truck will be used to deliver molasses to the injection site and keep it warm to allow a lower working viscosity. Frac tanks will be used to mix the nutrient slug and hold it prior to injection. The filter system will reduce the particulate matter in the injection fluid. The filter and recirculation pumps will be used to move the liquids between tanks and recirculate (roll) the fluids in the tanks to insure mixing. The Microbial Field Pilot Study (MFPS) triplex pump will be used to inject the nutrient slug into the main injection line to Well 7-2.

Figure 2-2 is a plan for the installation of the injection equipment. Activities read from right to left. The letters in brackets indicate what services need to be on location to accomplish these tasks.

A flow chart for the nutrient treatment injection is given in Figure 2-3. The molasses will be delivered to location in a hot oil truck. (See Figure 2-1.) The circulating liquid will be kept at $1400 \mathrm{~F}$ so that the molasses will be warm enough to flow 
but not hot enough to caramelize. When there is room in the molasses truck for additional fluid, brine will be added to the molasses and the resulting mixture circulated using the recirculation pump. This will quickly reduce the viscosity of the molasses and increase the recovery of the molasses from the hot oil truck. The molasses and brine will be mixed in approximately equal portions in Frac tank 1. The filter pump will be used to circulate (roll) this mixture to insure mixing. During circulation, ammonium nitrate will be added to tank 1 . The 50/50 nutrient/brine mixture will then be pumped through a filter to remove particulates larger than those found in the normal injection [formation] brine. The filtered mixture will then be stored in Frc tank 2 until it is pumped using a triplex pump into the main injection line which is simultaneously fed by the field injection pump. The resulting mixture will be $90 \%$ brine, $10 \%$ nutrient when it arrives at the sandface for injection. An alternative procedure (Figure 2-3) is to prepare a $90 / 10$ mixture in Frac Tank 2 which is injected directly into the formation using the MFPS triplex pump.

Approximately $1000 \mathrm{bbl}$ of the $90 / 10 \mathrm{mix}$ will be injected over two days with around 600 psig surface pressure. This will be followed by 5 days of brine injection using the field injection pump. The desired rate of injection is $500 \mathrm{bbl}$ per day. The purpose of this procedure is to have the nutrient mixture in the wellbore for as short a period as possible and use the brine flush to distribute the nutrients away from the wellbore and into the reservoir rock to avrsid microorganism growth in the wellbore.

Each production well will have a pumping unit (equivalent to a Bethlehem 57D) installed. Three quarter inch sucker rods will be used to lift a $1.5 \mathrm{in}$. plunger pump. The 2.5 in. tubing will be anchored just above the perforations. The wells will be pumped at rates to maintain a volume balance between injection and withdrawal. Figure $2-4$ is a plan for the installation of the production well units. The activities read from right to left. In both injection and production wells a well logging survey will be performed to determine porosity and fluid saturations behind the pipe. 
Figure 2-5 is a layout of the gathering system design. The flow lines will be 2 in. pipe of steel, fiberglass, or black polyethylene material. Other than the two strings that must be buried due to current land use it may be possibe to run the lines on the surface.

Figure 2-6 shows the separator and tank batteries required for this pilot. A simple "gunbarrel separator" will be used to separate the oil and produced water. One oil tank and two water tanks will be used to store the produced fluids. The oil will be sold by the field operator. We expect all of the produced water to be reinjected into the reservoir. 


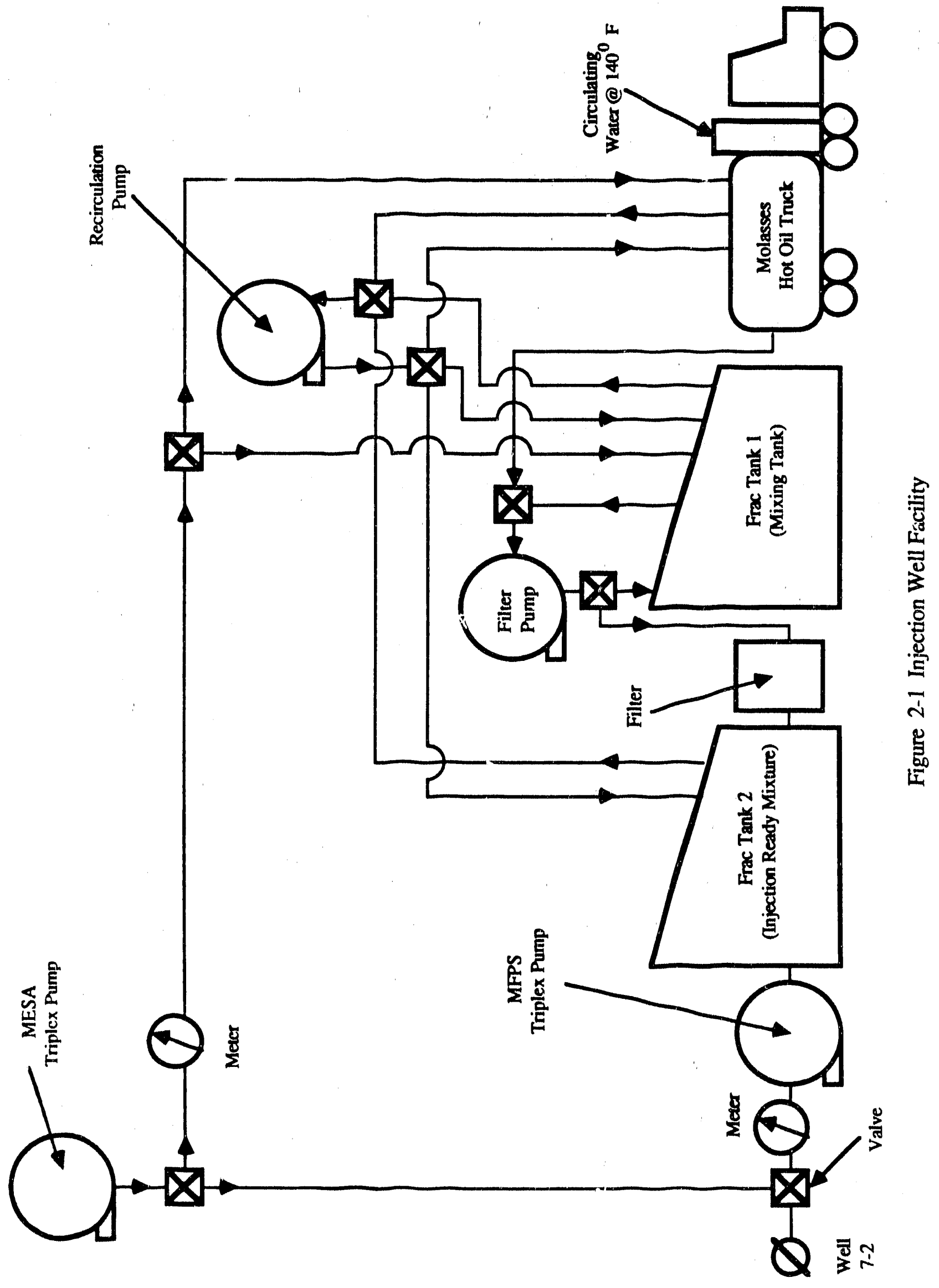



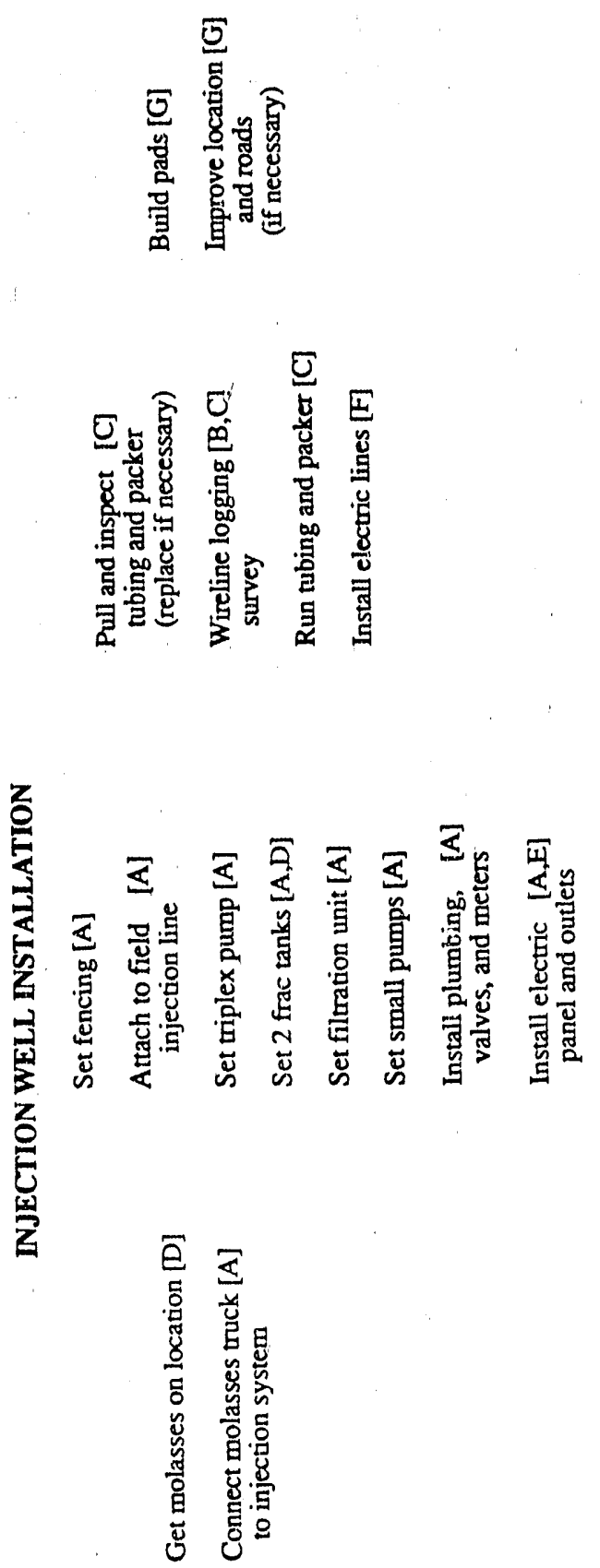

芯
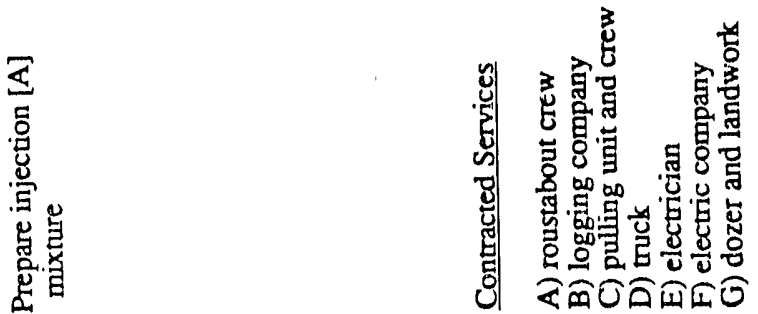

占㹂总 

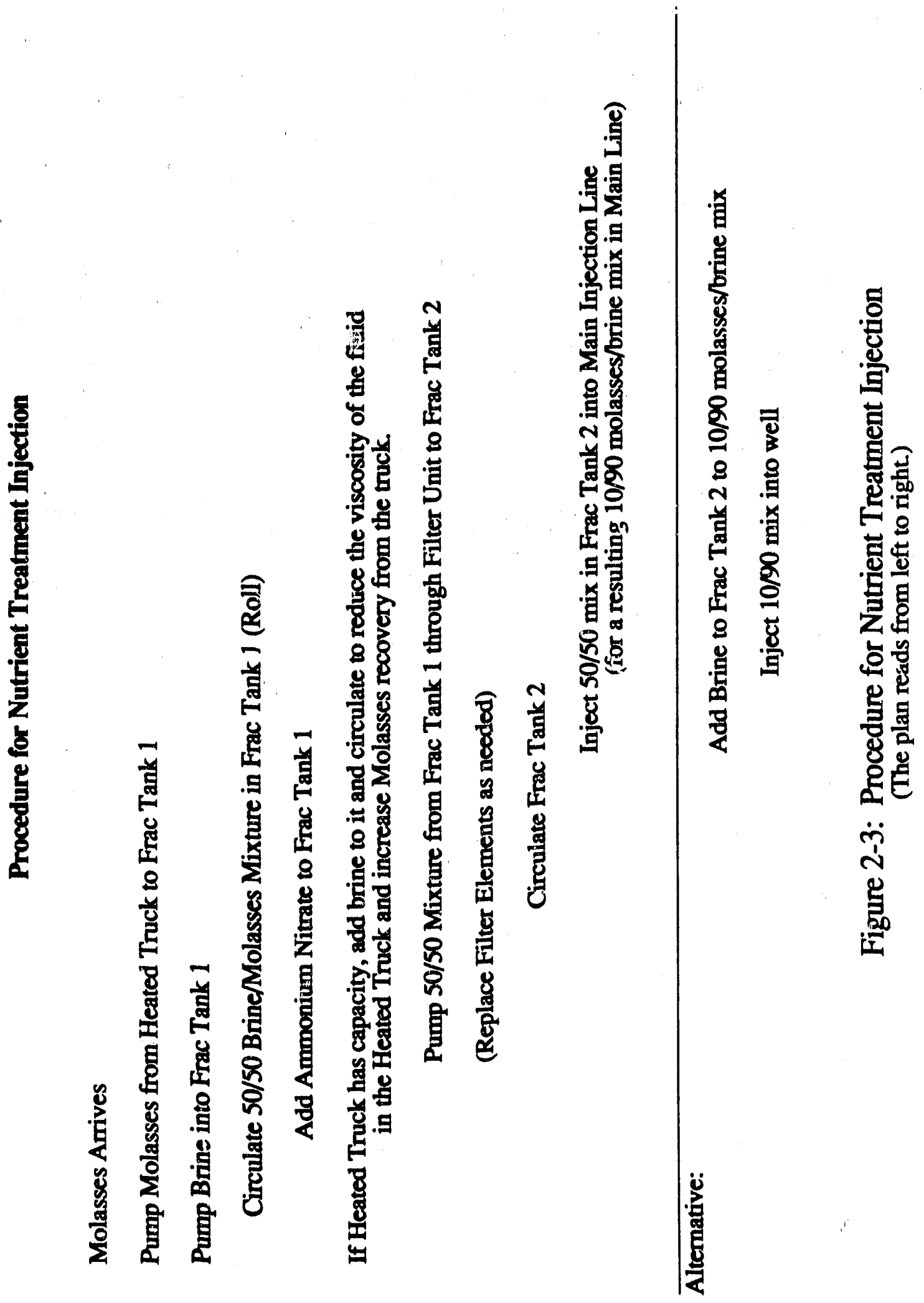

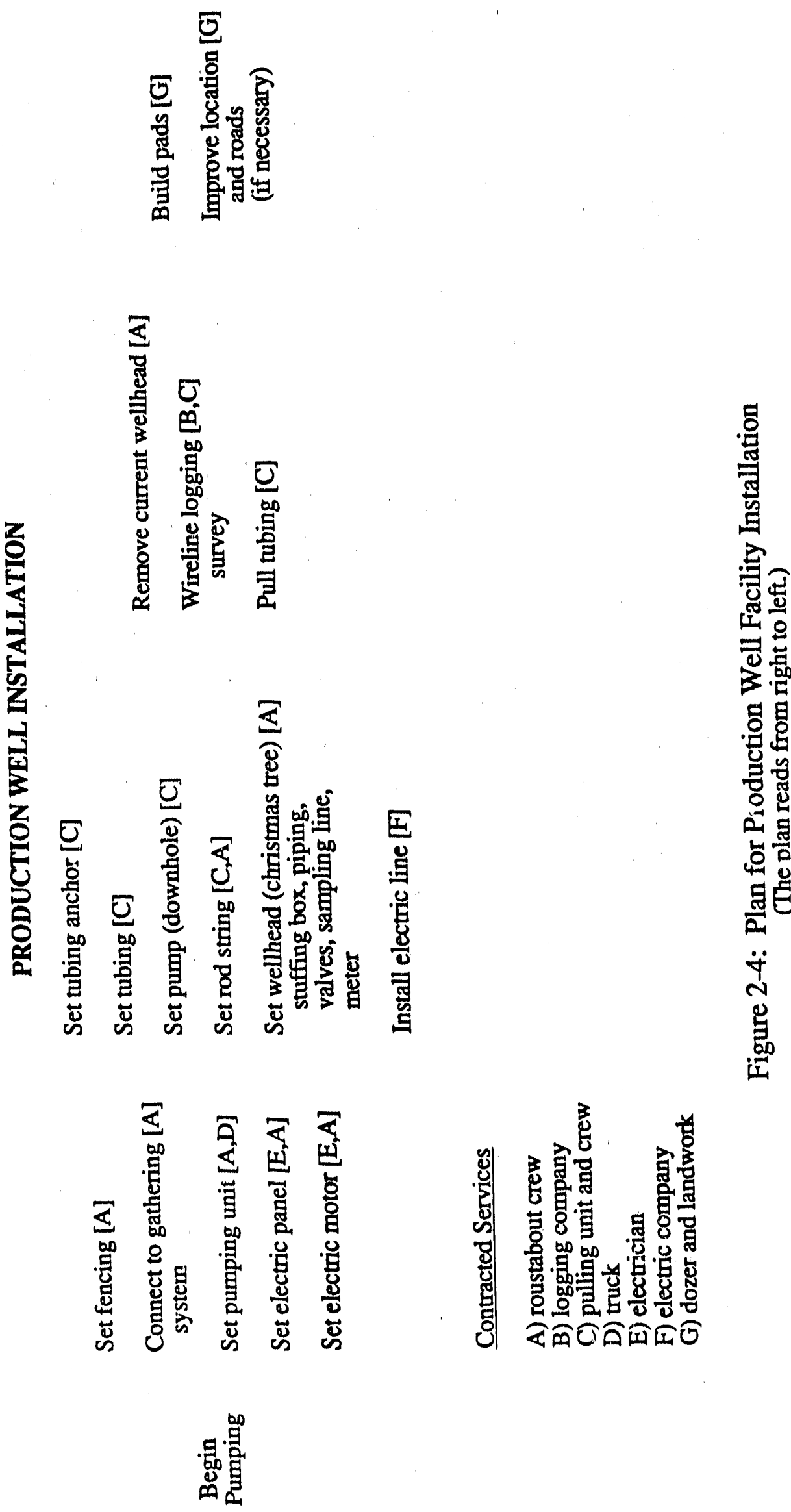


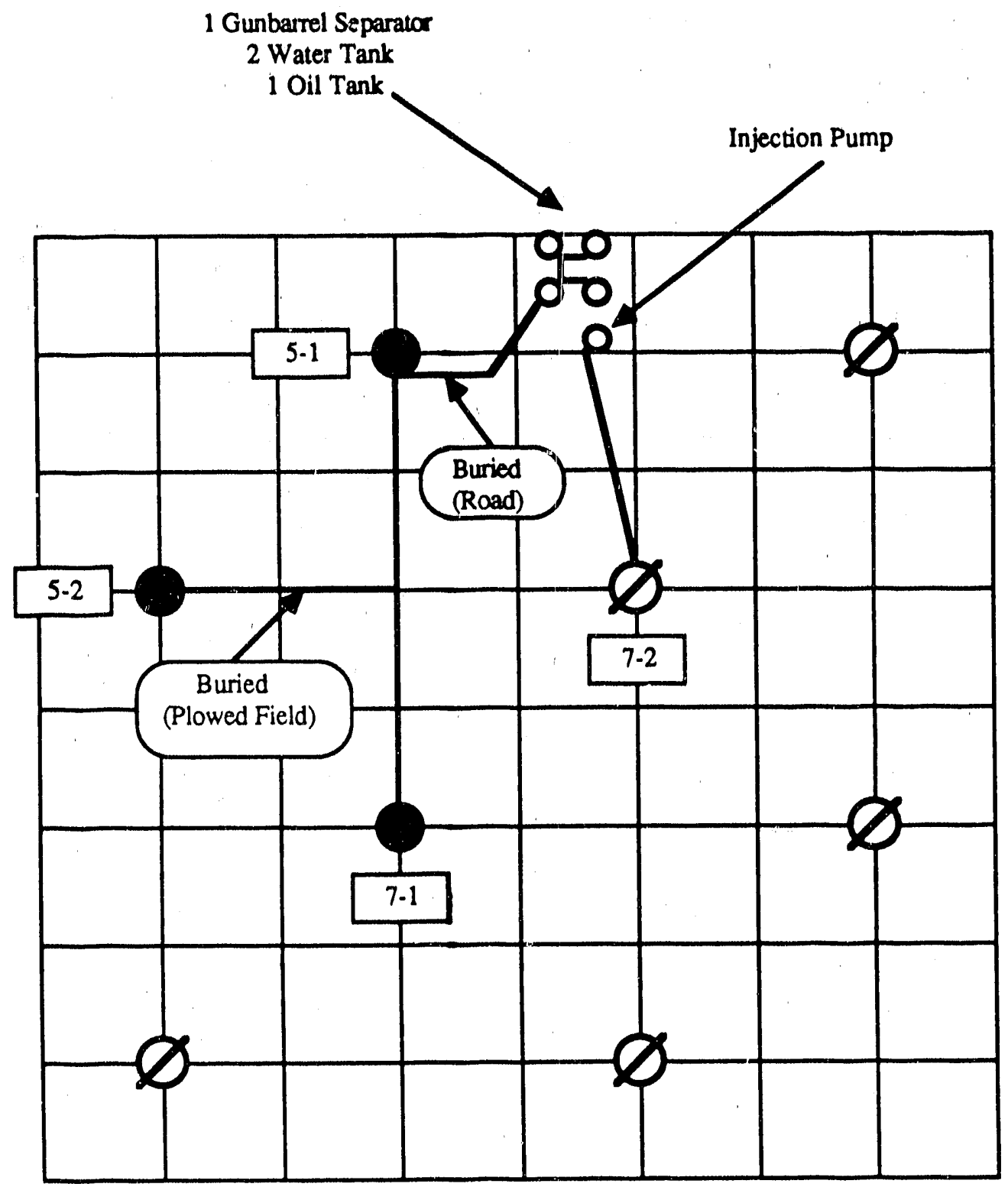

Figure 2-5 Gathering System Design 


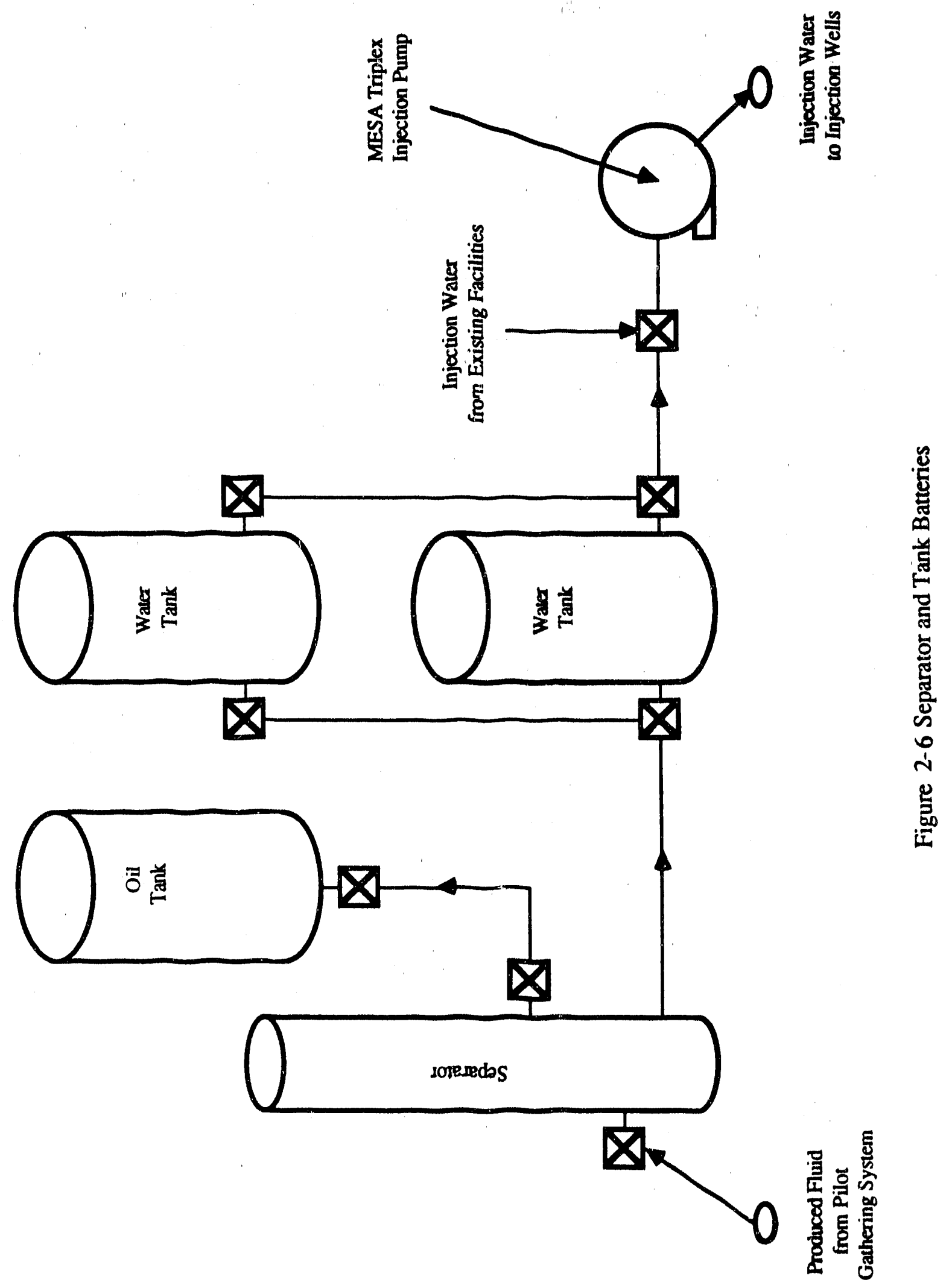




\section{The Southeast Vassar Vertz Sand Unit (SEVVSU)}

The field chosen for this pilot study is the Southeast Vassar Vertz Sand Unit. Figure 3-1 is a map of the geological regions of the state of Oklahoma [Oklahoma Geological Survey, 1972]. As indicated in the figure the Southeast Vassar field is located about 50 miles north northeast of Oklahoma City, Oklahoma. It is located on the northern shelf area of the Anadarko Basin. The Vertz sandstone belongs to the Wabaunsee Group of Pennsylvanian age.

The Southeast Vassar field was discovered in 1966. It was unitized in 1974 and a line drive waterflood was iniciated. The flood runs from southwest toward the northeast. As each production well exceeded a 10 to 1 water-oil ratio, it was converted to an injection well. The injection wells behind the active injectors are used to maintain pressure to insure that injected water continues to drive to the northeast. These pressure maintenance wells take little or no water. By 1987, the line of active injector welis was along the east edge of the southwest quarter of section 13.

The Vertz sandstone was probably formed by a meandering stream depositional system. Willhite [1986] presents an example of such an environment in his Figure 7.38. The Vertz is a uniform well-ordered sandstone which fines upward very gradually and has a basal lag of pebble size clasts. The sandstone has little vertical permeability variation and the preferential horizontal permeability lies in the paleocurrent direction. In a meandering stream system, a channel may become cut off forming an oxbow lake. If the abandoned channel is not subsequently reworked prior to system burial, it will fill with silt and form a clay plug. This will create a permeability barrier in the sandstone reservoir.

A net sand isopach of the Southeast Vassar Vertz Sand Unit is shown in Figure 3-2. Here, each major grid represents a quarter section. The solid line north of Well 5-1 and angling upward through the northwest quarter of section 13 is the location of a 
permeability barrier in the field. The barrier has been identified by the dry hole in this area and the lack of communication of flood waters across the barrier. To the southeast, the zero thickness line is broken since the true extent of the reservoir in this region is not known. The flow path of the depositional stream system appears to have been from northeast to southwest. This is likely the direction of the preferential permeability in the reservoir.

The isopach map is the result of reinterpreting the geological model of the reservoir de veloped by Tenneco and a reservoir characterization simulation study performed at the University of Oklahoma [Knapp, et al., 1989a, and Knapp, et al., 1989b]. The earlier geologic interpretation contained very little thickness in the southeast quarter of section 13 . The simulation study indicated that more reservoir volurne was necessary to support the production from the two wells located in that quarter section. A step-out development well (8-3) was drilled near the center of the southeast quarter (see Figure 3-2). Under the old interpretation this well should have encountered 2 to 4 feet of pay. The new well had 14 feet of pay. Elements of the geologic interpretation of the reservoir done after the completion of this well (8-3) are incorporated into the isopach map.

A fine grid simulation study of the SEVVSU is underway. The latest geological interpretation indicates that the permeability barrier isolates the northwestern part of the field from the region to the southeast. Based on this assumption, the fine grid model (Figure 3-3) only models the southeast portion of the field. The isopach map also changes slightly in response to the latest model. The grid is a single layer, two-dimensional, areal model of the reservoir. The grid has its maximum density in the region of the field pilot. The simulator used in this study is the BOAST II simulator [Fanchi, et al., 1987].

By May 1989, the cumulative oil production from the Southeast Vassar was 2.4 million stock tank barrels (STB) and 14 wells were operating as injectors or producers. 
The formation has a vertical depth of around $1800 \mathrm{ft}$. The original reservoir pressure was 850 psi. at $92 \mathrm{oF}$. Hydrometer readings have given oil gravities from 38 to 42 degrees API. From gas chromatography, gas gravities of from 0.70 to 1.18 (air $=1.0$ ) have been measured. In the reservoir simulation study, an oil gravity of 40 degrees API and a gas gravity of 0.85 were used. The oil and water viscosities are $2.9 \mathrm{cp}$ and $1.1 \mathrm{cp}$, respectively.

The Dykstra-Parsons permeability variation factor [Dykstra and Parsons, 1950], was 0.35 from core permeabilities indicating little vertical variability in permeability. Consistent with this is the high recovery obtained by the waterflood. In the region of the reservoir behind the flood front, it is estimated that primary and secondary recovery methods have produced almost $60 \%$ of the original oil in place. The mobile oil phase in the region planned for the pilot study may be as low as $5 \%$ of the original oil in place.

The microbial field pilot study is planned for the southwest quarter of section 13 behind the line of active waterflood injectors. Pumping units will be installed on wells 5-1, 5-2, and 7-1. The 7-2 well will become the injector for the pilot after workover operations to restore injectivity. With the three producers establishing a drawdown to the west and the active injectors functioning to the east, it is expected that all water injected in well 7-2 will be confined to the pilot area. Production and injection data on the four pilot wells will be collected for at least one month prior to nutrient injection to establish a baseline of reservoir performance. One thousand barrel slugs of approximately $10 \%$ nutrient solution will be injected into the injection well weekly for three months. This will be followed by continuing the waterflood. The production rates and pressures will be monitored and fluids sampled at the production wells until the reservoir has stabilized or for 18 months.

Based upon the current interpretation of paleocurrent direction, the preferential flow path is believed to be from the 7-2 to the 7-1. The effects of the injection are expected to be first seen at the 7-1 well. If the microbial process works as expected, this 
path will experience a permeability ieduction caused by the in situ growth of microorganisms. Later volumes of injected water will be diverted to wells 5-1 and 5-2. The goal of the pilot is to demonstrate that the flow paths can be changed in this region due to the growth and metabolism of indigenous bacteria. The field pilot may enhance oil recovery by sweeping some of the previously byf, $\Delta$ ssed oil.

Between the time the proposal was submitted to the Department of Energy and its subsequent funding, the Southeast Vassar Vertz Sand Unit working interest owned by Tenneco Exploration and Production Company (the unit operator) was sold to Mesa Limited Partnership. Conversations between the principal investigators, University Legal Counsel, and Mesa Limited Partnership have resulted in an agreement for the future operation of this field pilot study. This agreement was executed in late September 1989. Mesa has agreed to allow the continued use of the field and provide some technical assistance in the installation and operation of the field pilot. 


\section{References}

Dykstra, H. and R.L. Parsons, 1950. "The prediction of oil recovery by waterflood", Secondary Recovery of Oil in the United States, API, pp. 160-174.

Fanchi, J.R., J.E. Kennedy, and D.L. Dauben, 1987, "BOAST II: A Three-Dimensional, Three-Phase Black Oil Applied Simulation Tool", DOE/BC-88/2/SP, National Technical Information Service, Springfield, VA.

Knapp, R.M., J.L. Chisholm, M.J. McInerney, D.E. Menzie, 1989a, "Pre-test Studies and Design for a Microbially Enhanced Oil Recovery Field Pilot Study", Prodeedings of the Eighth Tertiary Oil Recovery Conference, March 8-9, 1989, Wichita, KS.

Knapp, R.M., M.J. McInerney, D.E. Menzie, R.A. Raiders, 1989b, "Microbial Field Pilot Study", Final Report, U.S. DOE/BC/14084-6, National Technical Information Service, Springfield, VA

Oklahoma Geological Survey, 1972, Geology and Earth Resources of Oklahoma, University of Oklahoma, Norman, OK.

Willhite, G.P., 1986, Waterflooding, SPE Textbook Series, Vol. 3, Society of Petroleum Engineers, Richardson, TX, p. 244. 


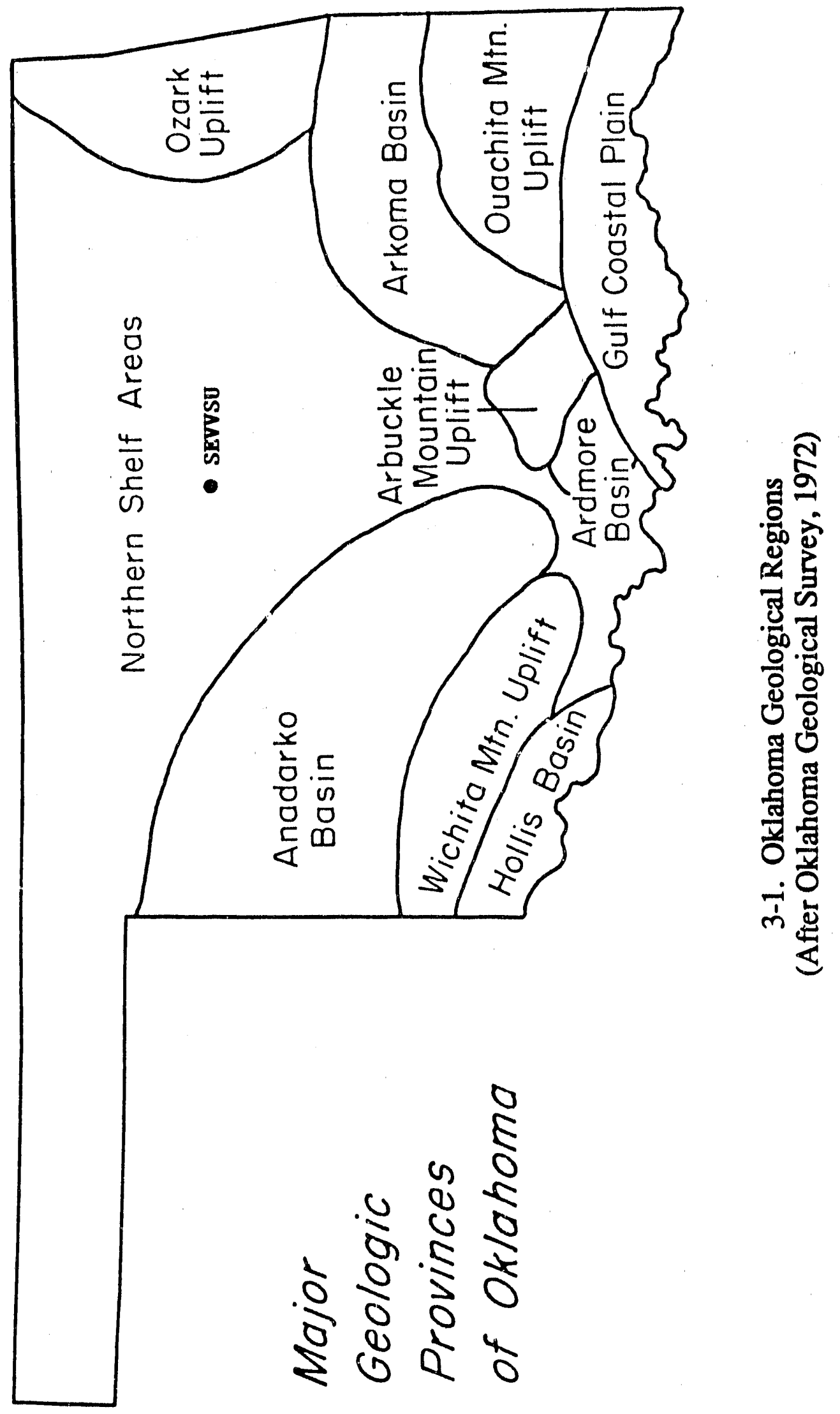


$B \cap W$

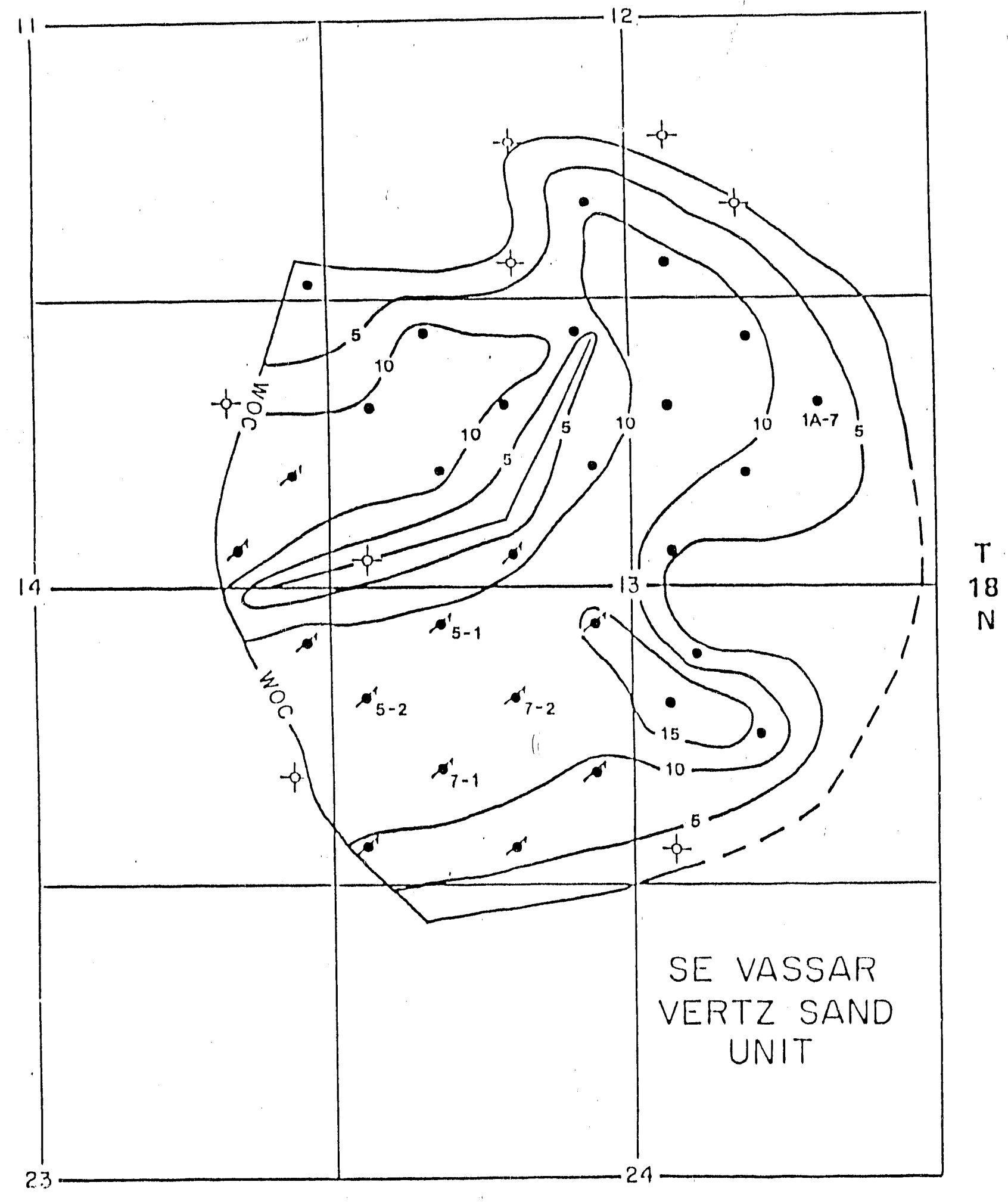

3-2. Net'laickness Map of Southeast Vassar Vertz Sand Unit (SEVVSU) 


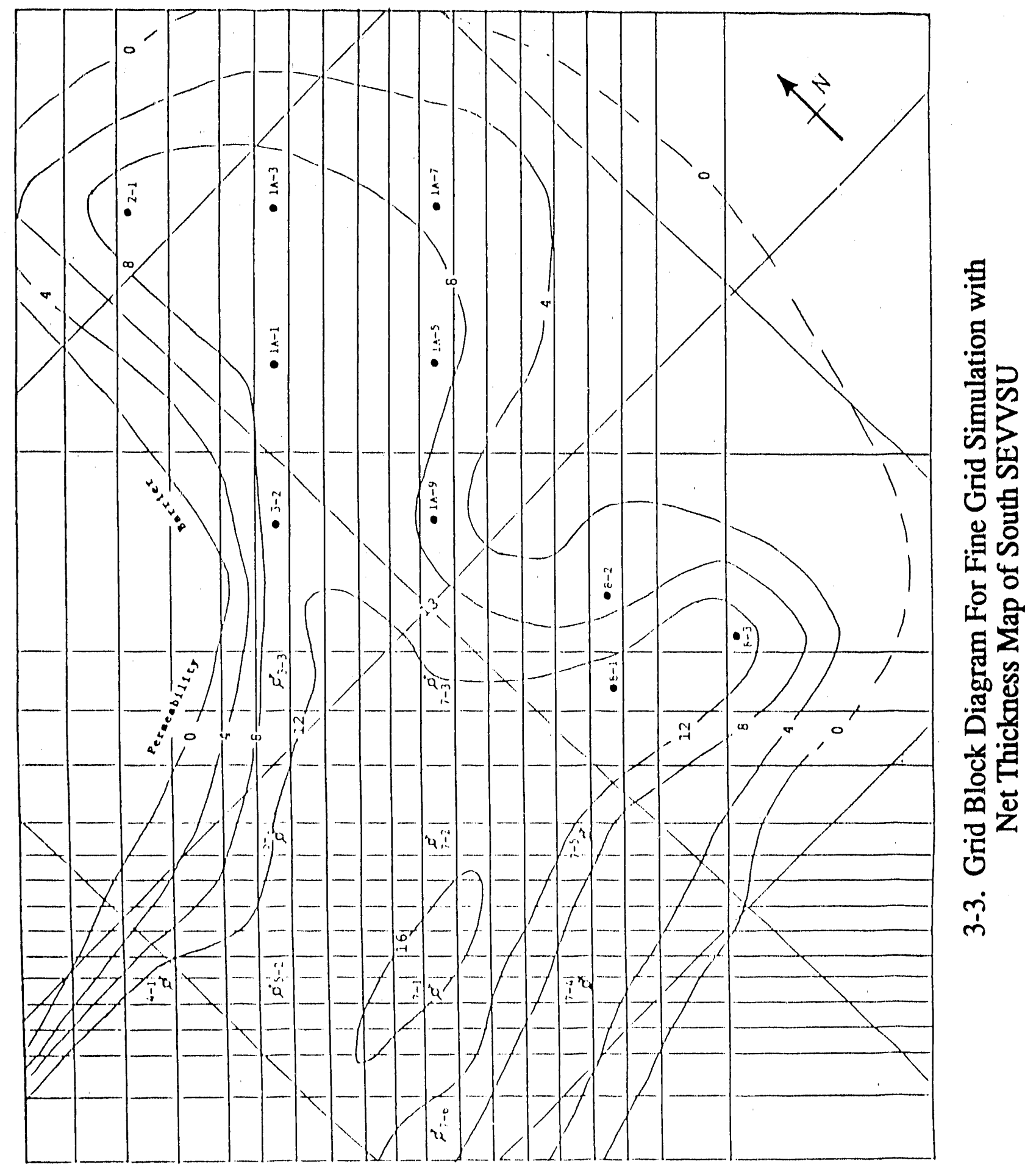




\section{CORE FLOOD EXPERIMENTS}

\subsection{INTRODUCTION}

Microbially enhanced oil recovery (MEOR) is an emerging technology that has the potential to recover a portion of the residual oil remaining in reservoirs after waterflooding. Some of the unique arivantages of MEOR are the ability to preferentially plug high permeability zones by multiplication of cell mass and the production of metabolic products. However, to ensure a high rate of success in the field, the mechanisms by which microorganisms enhance oil recovery must be understood.

\subsection{MECHANISMS OF MICROBIAL ENHANCED OIL RECOVERY}

The literature shows that there are three major mechanisms by which microorganisms may be used to enhance oil recovery:

(a) by selective plugging of formation flowpaths;

(b) by changing the chemical and/or physical properties of the reservoir fluids

(c) by destruction or alteration of the rock formation

\section{Selective plugging of formation flowpaths}

Almost all producing zones have variable permeability due to stratification, depositional environment, or diagenesis. This phenomena creates preferential flow paths for the displacing fluid (water). The invading fluid moves rapidly through the more permeable zones and more slowly in the less permeable zones. Once a continuous flow path has been established between the injection well and the production well, 
an increasing portion of injection water flows along this path. Thus, more oil is swept from the higher permeable zones, and less from the lower permeable portions. This reservoir heterogeneity greatly affects the recovery efficiency of the fluid displacement process. Selective plugging of these high permeability zones by microorganisms can improve sweep efficiency. Two types of microbial plugging have been identified: plugging by non-viable cells and plugging by viable microorganisms.

In early studies, non-viable microorganisms were used to study the plugging mechanism. Merkt [1943] was the one of the first to report the use of microorganisms in changing the permeability. Since dead cells do not produce slime, precipitates, etc, non-viable cells can only act as particlulate agents. Kalish, et al [1964] found that slime-forming and aggregated viable bacteria had a greater effect on permeability reduction per bacterium injected than did non-slime-forming or smaller bacteria (nonviable).

Since viable microorganisms can produce extracellular polymers, precipitates, etc. through their metabolic activity, the use of viable microorganisms should be able to recover more tertiary oil than the use of non-viable microorganisms. Viable microorganisms have the ability to adhere to the rock and produce an extracellular polysaccharide which covers the cells and the rock surface forming a polymer film. These actions result in more effective plugging than particulate plugging by dead cells. As the bacteria flourish and reproduce these activities exponentially increase. Thus, the cells become an effective plugging agent.

Crawford [1961,1962] was one of the first investigators to suggest the in-situ growth of bacteria could rectify permeability stratification. Since injection water tends to follow the least resistant flow paths, or highest permeability zones, bacteria transported with injection water will concentrate in those parts of the reservoir. With the 
ability of microorganisms to multiply themselves in-situ, higher permeable zones would be blocked by this mass of cells, and divert subsequent flow to lower permeability zones.

Myers and Samiroden [1967], Jenneman, et al [1983,1984], Torbati, et al [1986], Raiders et al. [1985,1986a,1986b], Jack et al. [1982], and Bryant and Douglas [1987] have all investigated the effects of viable microorganisms in porous media. One or more have concluded that viable microorganisms can penetrate por us media, reduce permeability by as much as $90 \%$, preferentially plug higher permeability zones and larger pores, and produce chemicals and gases which improve recovery.

\section{Chemical changes and processes affecting reservoir fluids}

Several chemical changes occur as a result of the MEOR processes which affect the fluids in the reservoir. Microbial processes result in a change in the relative permeability relationship from two phases to three phases. The metabolism of many microorganisms may result in the production of carbon dioxide, nitrogen, or possibly methane, which can create a free gas phase in the reservoir. A free gas phase has been found to decrease residual oil saturation. Holmgren and Morse [1951] used Nellie Bly sandstone to study waterflood recoveries with varying initial gas and oil saturations. They observed that increasing the initial free gas saturation caused the residual oil saturation to decrease. The presence of a gas phase caused a decrease in residual oil saturation of six to ten percent of pore volume. The generation of a free gas phase in a core without one can account for a fifth to a third of the residual oil recovered after waterflooding. Kyte et al. [9] conducted experiments on water-wet and oil-wet cores. They found that lower residual oil saturations were obtained at successive

flooding stages when gas was present compared to those floods performed in the 
absence of gas. Greater reductions in residual oil saturations occured in the presence of increasing mobile gas saturations of up to $15 \%$. With further increases in initial gas saturations, the corresponding reductions in residual oil saturations become less pronounced.

Biosurfactants and cosurfactants (alcohols) are produced as a byproduct of the MEOR process (Javaheri, et al [1985]). Surfactants lower the interfacial tension at the oil-water interface and displace oil that cannot be displaced by water alone. Capillary forces that trap residual oil in porous media are reduced by lowering interfacial tension. One of the problems of surfactant flooding is the adsorption of surfactant on the surface in the reservoir rock. This decreases the concentration of the surfactant below that required to perform the task. This problem maybe less likely to occur if the surfactant could be produced in-situ.

Oil displacement by water from a porous system is believed to be governed by competition between viscous and capillary forces. Melrose and Bradner [1974] introduced the term capillary number $\left(\mathrm{N}_{\mathrm{ca}}\right)$ to relate the magnitude of viscous forces to the magnitude of the capillary fcrces. They define it as:

$$
N_{c a}=\frac{V \mu_{w}}{\sigma_{o w}}
$$

where

$\mathrm{N}_{c a}$ : capillary number, dimensionless

$V \quad:$ interstitial velocity, $\frac{u}{\phi}$

$\mu_{w} \quad$ : viscosity of displacing fluid

$\sigma_{\text {ow }}:$ interfacial tension between oil and the displacing fluid

The reduction in interfacial tension caused by the in situ surfactant and 
alcohol generation increases microscopic displacement enficency in the porous medium and reduces the residual oil saturation (Moore and Slobod [1956]). This is illustrated in Figure 4-1 by the capillary desaturation curve (after Stalkup [1984]) where the nonwetting phase (oil) residual saturation is plotted as a function of dimensionless capillary number. At low values of the capillary number $\left(<10^{-6}\right)$, the residual oil saturation is nearly constant. In this region the residual oil saturation is almost independent of viscous forces. At the critical value of $\mathrm{N}_{c a}$, above which residual oil saturation decreases, the displacement process is in a transition from one dominated by capillary forces to one controlled by competition between viscous forces and capillary forces. Further increases in capillary number result in decreases in residual oil saturation and improved oil recovery.

The effective permeability reduction factor (PRF) can be defined as:

$$
\mathrm{PRF}=\frac{\mathrm{K}_{\mathrm{wi}}}{\mathrm{K}_{\mathrm{wsor}}} 100
$$

where:

PRF : effective permeability reduction factor, percent

$\mathrm{K}_{\mathrm{wi}}$ : effective brine permeability of the core during i-th treatment, $\mathrm{mD}$

$\mathrm{K}_{\mathrm{wsor}}$ : effective brine permeability of the core at residual oil saturation, $\mathrm{mD}$

In MEOR processes, a series of nutrient treatments are used to improve oil recovery. The incremental oil recovery associated with each nutrient treatment is the oil produced by the release of pressure caused by the in situ gas produced during incubation of the core with nutrients plus the oil that is produced by the injection of the subsequent treatment. The recovery factor $(R F)$ is defined as: 


$$
\mathrm{RF}=\frac{\mathrm{N}_{\mathrm{p}}}{\mathrm{OIPW}} 100, \%
$$

where

$\mathrm{N}_{\mathrm{p}}$ : cumulative oil production after MEOR treatments, $\mathrm{ml}$ OIPW : Oil In Place after Waterflood $\left(\mathrm{S}_{\mathrm{or}}{ }^{* P V}\right), \mathrm{ml}$

A relationship between the capillary number after $\mathrm{i}$ treatments, $\mathrm{N}_{\mathrm{ca}}^{\mathrm{i}}$, and the capillary number before treatment, $\mathrm{N}_{\mathrm{ca}}^{\circ}$, can be developed. This relationship is based on the definition of capillary number and permeability reduction factor (PRF). If the viscosity of water and the Darcy velocity are unchanged by the treatment, then:

$$
\left[\frac{N_{c a}^{i}}{N_{c a}^{o}}\right]=\left[\frac{\phi_{o}}{\phi_{i}}\right]\left[\frac{\sigma_{o w}^{o}}{\sigma_{o w}^{i}}\right]
$$

A correlation of the rate of change in porosity versus the rate of change in permeability due to selective plugging by micruorganisms was introduced by Civan et al. [1988]:

$$
\mathrm{PRF}=\frac{\mathrm{K}_{\mathrm{i}}}{\mathrm{K}_{\mathrm{o}}}=\left[\frac{\phi_{\mathrm{i}}}{\phi_{\mathrm{o}}}\right]^{3}
$$

Substituting this expression into the capillary number ratio expression results in:

$$
\left[\frac{N_{c a}^{i}}{N_{c a}^{o}}\right]=\left[\frac{1}{P R F}\right]^{1 / 3}\left[\frac{\sigma_{o w}^{o}}{\sigma_{o w}^{i}}\right]
$$

\section{Formation destruction}

Acids are produced by certain bacteria as a byproduct of metabolism. If the 
porous medium is a carbonate (limestone) or has carbonate cement between individual clasts, then acid production can modify the rock system. It is not known whether in situ metabolic acids can be produced in sufficient quantities to have significant effects on the lithology of carbonates.

\subsection{EXPERIMENTAL ANALYSIS}

The experiments described in this section were conducted to provide information about the mechanisms of oil recovery caused by microbial activity withir a core. Specifically, samples of microorganisms from one of the wells in the Southeast Vassar Vertz Sand Unit (SEVVSU), Payne County, Oklahoma were investigated for their potential in microbial enhancement of oil recovery. All experiments were performed using oil and brine taken from the SEVVSU. The $\mathrm{NaCl}$ salinity of the brine was around $15 \%$. The experiments were performed at reservoir temperature.

\section{Core preparation}

Cores, two inches in diameter and six inches in length, were cut from Berea sandstone. Initial permeability values ranged from 84 to $724 \mathrm{md}$. The cores were cleaned by extraction with toluene and then were steam cleaned to remove humic acid and organic matter. After steam cleaning, the cores were dried at $125^{\circ} \mathrm{C}$. The cores were prepared for flooding according to the method of Menzie [1988] with a pressure tap installed at the midpoint of the core.

Figure 4-2 shows a schematic of the experimental apparatus used. A positive displacement metering pump was used to inject liquids into the core. The core assembly was placed in an oven at constant temperature of $35^{\circ} \mathrm{C}$. A $50 \mathrm{ml}$ plastic syringe 
with a Luer lock was used to collect the effluent from the downstream end of the core. The use of the syringe provided a simple method to collect all three phases distinctively by gravity segregation and avoided air contamination.

Each core was flushed with carbon dioxide to provide an anaerobic environment and then flooded with Vertz brine flushed with nitrogen to minimize oxygen content. The porosity was determined gravimetrically. The absolute permeability was measured (Jenneman, et al [1984]) and the core flooded with Vertz crude oil to irreducible water saturation. The core was then flooded with brine to irreducible (residual) oil saturation. The effective brine permeability of the core was determined. After these steps, each core was treated with one or more inoculations of bacteria indigeneous to the Vertz sand unit. The bacterial population was enriched by adding $1 \%$ (vol/vol) molasses and $0.3 \%\left(\mathrm{wt} / \mathrm{vol}\right.$ ) ammonium nitrate $\mathrm{NH}_{4} \mathrm{NO}_{3}$ to brine collected from well $1 \mathrm{~A}-9$. The nutrient ammended brine was incubated at $32^{\circ} \mathrm{C}$ until growth occured. As many as 10 treatments of a nutrient mixture (Vertz brine $+1 \%$ molasses $+.3 \% \mathrm{NH}_{4} \mathrm{NO}_{3}$ ) were performed on each core. Injection rates (flow volume per unit time) were kept constant and low to assure laminar flow.

During each treatment, brine flow rates and differential pressures across the core were measured to determine the effective brine permeability of the core. The effective permeability reduction factor (PRF) was then determined for each treatment.

The effluent brines were analyzed to calculate carbon and nitrogen balances and to determine the surface tension. The gases were analyzed using a gas chromatograph. Volatile fatty acids and alcohol concentrations in the brine were determined on a gas chromatograph equipped with a flame ionization detector and a fused silica column. Carbohydrate and nitrate concentration in the brine were determined colorimetrically. For one of the cores, C06, the surface tension and viscosities of the 
brines were determined. The surface tension of the influent and effluent brine was determined using a DuNouy ring tensiometer. Viscosity of the influent and effluent brine was determined using a Cannon-Fenske viscometer.

\section{Theoretical calculations}

In predicting the gas products in the effluent samples of each treatment, a theoretical balance of nutrient consumption was developed. These calculations provided an estimate of the products that formed as a result of metabolization by microorganisms. Molasses consists of various mono and disaccharides of hexose sugars. In the theoretical calculations, the empirical formula of a hexose, i.e. glucose, was used to represent all the carbohydrate in molasses.

The theoretical calculation of the product concentrations of hexose and nitrate result from a stoichiometric balance of the reaction equations. Microorganisms metabolize hexose to acetate $\left(\mathrm{CH}_{3} \mathrm{COO}^{-}\right)$and carbonate $\left(\mathrm{HCO}_{3}^{-}\right)$in the presence of the electron receptor, nitrate, which is reduced to nitrogen. Combining these reactions gives the theoretical reaction:

$5 \mathrm{C}_{6} \mathrm{H}_{12} \mathrm{O}_{6}+8 \mathrm{NO}_{3}^{-} \longrightarrow 10 \mathrm{CH}_{3} \mathrm{COO}^{-}+10 \mathrm{CO}_{2}+4 \mathrm{~N}_{2}+9 \mathrm{H}_{2} \mathrm{O}+2 \mathrm{H}^{+}$

The nutrient mixture used contained $1 \%$ molasses. This molasses was feed grade molasses consisting of $48 \%$ to $58 \%$ carbohydrates (hexose). The remainder being vitamins, minerals, other chemicals, and water. Assuming molasses is composed of $58 \%$ hexose sugers (glucose equivalents) leads to the following theoretical product concentrations in the effluent:

$\mathrm{CH}_{3} \mathrm{COO}^{-}=0.033 \frac{10}{5}=0.067$ moles acetate $/ 1$ 


$$
\begin{aligned}
& \mathrm{CO}_{2}=0.033 \frac{10}{5}=0.067 \text { moles } \mathrm{CO}_{2} / 1 \\
& \mathrm{H}_{2} \mathrm{O}=0.033 \frac{9}{5}=0.060 \text { moles } \mathrm{H}_{2} \mathrm{O} / 1 \\
& \mathrm{~N}_{2}=0.0376 \frac{4}{8}=0.0188 \text { moles } \mathrm{N}_{2} / 1
\end{aligned}
$$

\subsection{CORE EXPERIMENTS}

Core experiments were performed on four Berea sandstone cores designated $\mathrm{C} 06, \mathrm{CO}, \mathrm{C10}$, and $\mathrm{C} 11$. For each nutrient treatment these cores were monitored for cumulative gas production $\left(G_{p}\right)$, permeability reduction factor $(P R F)$, and oil recovery factor (RF). The results are given for these experiments in Tables 4-1 through 4-4.

\section{Core Number 06}

During the waterflood, 2.6 PV of brine displaced $59.1 \%$ of original oil in place (OOIP) from core C06. Figure 4-3 show's permeability reduction factor (PRF), cumulative incremental oil recovery factor, and gas production for core C06. At the end of the treatments, approximately 10 PV of nutrient mixture had been injected and $84.2 \%$ of the oil in place after waterflooding had been recovered. This represents an additional $34.4 \%$ of OOIP. The total gas prodiced was $217.6 \mathrm{ml}$ (at approximately $70^{\circ} \mathrm{F}$ and 1 atm.) with an average concentration of $70.2 \%$ of $\mathrm{N}_{2}$ and $25.1 \% \mathrm{CO}_{2}$. At the end of the nutrient treatments, 2.6 PV of Vassar brine were injected through the core, and the PRF value stabilized at $4.9 \%$. 
In core $\mathrm{C} 06$, no significant oil and gas were recovered during the first three treatments. After three treatments, the microorganisms had acclimated to the environment and started to utilize the carbon sources, resulting in the production of biogenic gas and other microbial products. The surface tension of the effluent samples was found to be $52 \%$ of the injected nutrient mixture. The viscosity of the effluent was the same as the injected nutrient mixture.

Theoretically $232.6 \mathrm{ml}$ of $\mathrm{N}_{2}$ and $828 \mathrm{ml}$ of $\mathrm{CO}_{2}$ should have been produced by C06. Analysis of recovered gas indicates $147.8 \mathrm{ml}$ of $\mathrm{N}_{2}$ (63.5\% of theoretical) and $67.4 \mathrm{ml}$ of $\mathrm{CO}_{2}$ (8.14\% of theoretical) was produced.

\section{Core Number 09}

During the waterflood by $2.8 \mathrm{PV}$ of Vassar brine, $58.1 \%$ of OOIP was recovered in core C09. Figure 4-4 shows PRF, cumulative incremental oil recovery and gas production for this cc:e. At the end of eight treatments, after approximately $6 \mathrm{PV}$ of nutrient mixture had been injected, an additional $22.6 \%$ OOIP was recovered for a $53.9 \%$ incremental oil recovery. The cumulative gas production was $135 \mathrm{ml}$ with an average concentration of $65 \% \mathrm{~N}_{2}$ and $6 \% \mathrm{CO}_{2}$. After the final nutrient treatments, 2.2 PV of Vassar brine were injected through this core and the PRF was stabilized at $15.5 \%$.

\section{Core Number 10}

Core 10 developed extensive plugging on the injection face and produced very little oil and gas. Although six treatments were performed the permeability 
reduction primarily occurred in the front half of the core. Figure 4-5 shows PRF, cumulative incremental oil recovery and gas production for this core. After injecting 1.9 PV of Vassar brine through the core at the final treatment, the IRF for the front half and back half of the core stabilized at $10.6 \%$ and $64 \%$ respectively.

\section{Core Number 11}

Core C11 was treated in a manner similar to the other cores. During waterflood, 2.3 PV of brine recovered 40.3\% OIIP. Figure 4-6 shows PRF, cumulative incremental oil recovery and gas production. At the end of the sixth treatment, after approximately 5 PV of nutrient mixture were injected, $8.7 \%$ of incremental oil recovery or an additional of 5.4\% OOIP was recovered. The total gas produced was $5.2 \mathrm{ml}$ with an average concentration of $64 \% \mathrm{~N}_{2}$ and $26 \% \mathrm{CO}_{2}$. After injecting 1.9 PV of Vassa' brine through the core after the final treatment, the FRF stabilized at $15.7 \%$.

Although experiment $\mathrm{C} 11$ recovered residual oil, recovery was much lower than cores $\mathrm{C} 06$ and $\mathrm{C} 09$. Despite artaining a low PRF, oil and gas production were not substantial. The core's initial permeability might explain low recovery since the original absolute permeability of the core was less than $100 \mathrm{md}$. The small amount of biogenic gas produced can also explain this low recovery. This result substantiates previous work done by Raiders et al. [1985] and Jenneman et al. [1983] indicating that low permeability appears to limit the microorganisms ability to proliferate and produce by-products. 


\subsection{DISCUSSION OF RESULTS}

For Cores $\mathrm{C} 06$ and $\mathrm{C} 09$, as the permeability reduction factor started to decrease below $25 \%$, oil recovery increased substantially. This suggests that microorganisms had preferentially plugged the higher permeability regions within the core and diverted the flow of the brine to the lower permeability (unswept) regions where more oil was trapped, apparently increasing the sweep efficiency of the flood. In C06, carbon and nitrogen analyses were also performed. $\mathrm{CO}_{2}, \mathrm{~N}_{2}$, acetate, butyrate and ethanol were detected in the effluent samples. The results show that microorganisms proliferated and produced metabolic products that helped recover more oil.

Carbon recovery in the analyses was low. It was possible that other carbon components such as lactate were present in the effluent but were not detected by the gas chromatographic method used. The comparison of the theoretical calculations and experimental results for $\mathrm{CO}_{2}$ shows that $\mathrm{CO}_{2}$ recovery in the effluent was much lower than expected. This can be partially explained by the solubility of $\mathrm{CO}_{2}$ in brine (in the form of $\mathrm{H}_{2} \mathrm{CO}_{3}$ or $\mathrm{HCO}_{3}^{-}$) and in the oil. Further, since the Vertz brine has high concentrations of $\mathrm{Ca}^{+}$, the carbon dioxide may have formed $\mathrm{CaCO}_{3}$ which precipitated within the core. Finally, the amount of carbon involved in the production of cells is not accounted for in the empirical equation. The higher percentage of $\mathrm{N}_{2}$ recovered and the complete consumption of nitrate in the later treatments suggests that the denitrification occured in the core.

The presence of biogenic gas in the core can explain some of the additional oil recovery. In most porous media the system is water wet, that is, the surface of the rock is in contact with water, the wetting phase. If present, oil and gas occupy the center of the pores with a buffer of water between them and the rock, and are con- 
sidered non-wetting. The absolute permeability of the rock is the capacity of the rock to conduct fluid with only one phase present. Relative permeability is the fraction of this capacity available to a specific phase when multiple phases are present. Relative permeability is a function of the phase and the saturations of the phascs present. Figure 4-7 depicts idealized wetting phase relative permeability, $k_{r w}$, and non-wetting relative permeability, $\mathrm{k}_{\mathrm{mw}}$, versus wetting phase saturation. In a core at residual oil saturation, the emergence of a free gas phase will increase the non-wetting saturation and oil will become more mobile. Based on the work of Holmgren and Morse [1951] this could account for the recovery of about a fifth to a third of the oil left after waterflooding.

Microscopic displacement efficiency also increased by changes in the chemical composition of the fluid. One of the products, ethanol is soluble in the oil. Ethanol production can increase microscopic displacement efficiency by decreasing the viscosity of oil. The surface tensions of the effluent brine samples were lower than the initial nutrient samples. This suggests that biosurfactant was also produced. Thus, microbial processes lead to reduction of the oil viscosity and surface tension which increase oil mobility and capillary number.

The growth of microorganisms within the core generates cellular material which reduces the porosity of the core. As microbial cells are produced, they attach to the walls of the pores. This reduces the volume of the pore which is available for fluid flow. Since all of the experiments were conducted at a constant volumetric injection rate, the fluid velocity in pores with microbial growth must have increased. Further, if some of the pore throats are completely blocked, the flow normally associated with these pores is diverted to other pores. Both of the above factors will lead to an increase in interstitial fluid velocity within those pores still available to fluid flow. 
This increase in interstitial fluid velocity increases capillary number and oil recovery.

For core C06, using a stabilized PRF of 5\% and a surface tension 52\% of original value and assuming that the reduction in the interfacial tension between oil and water was the same as the reduction in surface tension, the change in the capillary number ratio for core $\mathrm{C} 06$ is

$$
\left[\frac{\mathrm{N}_{\mathrm{ca}}^{\mathrm{i}}}{\mathrm{N}_{\mathrm{ca}}^{\mathrm{o}}}\right]=\left[\frac{1}{0.05}\right]^{1 / 3}\left[\frac{1}{0.52}\right]=5.2
$$

The capillary number after treatment was 5.2 times capillary number bef re treatment. From Figure 4-1, assuming $\mathrm{N}_{\mathrm{ca}}^{0}=10^{-6}$, the increase of 5.2 in capillary number could have caused a decrease in residual oil saturation of 5\% and the increase in capillary number could explain a 15 to $20 \%$ additional oil recovery.

\subsection{CONCLUSIONS}

(1) Increases in oil recovery were accompanied by production of biogenic gas, acids, ethanol and biomass by native bacteria collected from well 1A-9 of SEVVSU.

(2) Production of biogenic gas decreases the residual oil saturation due to relative permeability changes associated with the creation of a free gas phase in the reservoir. This can explain the recovery of a fifth to a third of the oil left after waterflooding.

(3) The increase in capillary number for core C06 can explain $15-20 \%$ additional oil recovery. 
(4) The mechanisms in conclusions (2) and (3) were active in the core experiments but do not fully explain the the additional oil production observed in cores C06 and C09. The contributions to recovery of other mechanisms, such as selective plugging, have not yet been quantified. Additional mechanisms which may be active have not yet been identified. 


\section{REFERENCES}

Bryant, R.S. and J. Douglas. 1987. Evaluation of Microbial Systems in Porous Media for Enhanced Oil Recovery, presented at the Society of Petroleum Engineers International Symposium on Oilfield Chemistry, San Antonio, Tx, Feb. 1987.

Civan, F., R.M. Knapp, and H.A. Ohen. 1988. Automatic Estimation of Model Parameters for Swelling and Migration of Fine Particles in Porous Media, Paper presented at the AICHE Meeting in New Orleans, LA, (March 6-10, 1988).

Crawford, P.B. 1961. Possible Bacterial Correction of Stratification Problems, Prod. Monthly, vol 25, 10-11.

Crawford, P.B. 1962. Water Technology: Continual Changes Observed in Bacterial Stratification Rectification, Prod. Monthly, vol 26, 12.

Holmgren, C.R. and R.A. Morse. 1951. Effect of Free Gas Saturation on Oil Recovery by Waterflooding, Transactions, AIME, 192, 285-296.

Jack, T.R., B.G. Thompson, and E. DiBlasio. 1982. The Potential for Use of Microbes in the Production of Heavy Oil, Proceedings of the 1982 International Conference On the Microbial Enhancement of Oil Recovery, Afton, Oklahoma, (May 1982), 88-93.

Javaheri, M., G.E. Jenneman, M.J. McInerney, R.M. Knapp. 1985. Anerobic Production of a Biosurfactant by Bacillus licheniformus JF-2, Applied Environmental Microbiology, (September 1985), 689-700.

Jenneman, G.E., R.M. Knapp, D.E. Menzie, D.E. Revus, J.B. Clark, and D.M. Munnecke. 1983. Transport Phenomena and Plugging in Berea Sandstone Cores Using Microorganisms, In, E.C. Donaldson and J.B. Clark, (eds.) Proceedings of the 1982 International Symposium on Microbial Enhancement of Oil Recovery, Nat. Tech. Inf. Serv., Springfield, V.A, CONF-8205140 71-75.

Jenneman, G.E., R.M. Knapp, M.J. McInerney, D.E. Menzie, and D.E. Revus. 1984. Experimental Studies of In-Situ Microbial Enhanced Oil Recovery, Soc. Pet. Engr. J., (Feb. 1984) 33-37.

Kalish, P.J., J.E. Stewart, W.F. Rogers, and E.O. Benneth. 1964. The Effect of Bacteria on Sandstone Permeability, J. Pet. Tech., vol 16, 805-814.

Kyte, J.R., R.J. Stanclift, Jr., S.C. Stephen, Jr., and L.A. Rapoport. 1956. Mechanism of Water Flooding in The Presence of Free Gas, Trans., AIME 207, 215-221.

Melrose, J.C. and C.F. Brandner. 1974. Role of Capillary Forces in Determining Microscopic Displacement Efficiency for Oil Recovery by Waterflooding, J. Cdn. Pet. Tech., (Oct. - Dec. 1974) 54-62.

Menzie, D.E., S. Dutta, and R.S. Shadizadeh. 1988. A New Method of Coating Oilfield Core for Laboratory Studies, J. Pet. Tech., (May 1988) 643. 
Merkt, E.E. 1943. The Effect of Bacteria on the Permeability of Oil Reservoir Rocks, Thesis, University of Texas, Austin, 'Texas, 14-29.

Moore, T.F. and R.L. Slobod. 1956. The Effect of Viscosity and Capillarity on The Displacement of Oil by Water, Prod. Monthly, (Aug. 1956) 20-30.

Myers, G.E., and W.D. Samiroden, 1967. Bacterial Penetration in Petroliferous Rocks, Prod. Monthly, (April 1967) 22-25.

Raiders, R.A., D.C. Freeman, G.E. Jenneman, R.M. Knapp, M.J. McInerney, and D.E. Menzie. 1985. The Use of Microorganisms to Increase the Recovery of Oil Form Cores, Paper SPE 14336 presented at the 60th Annual Meeting of the Society of Petroleum Engineers of AIME, Las Vegas, NV, Sept. 1985.

Raiders, R.A., M.J. McInerney, D.E. Revus, H.M. Torbati, R.M. Knapp, and G.E. Jenneman. 1986a. Selectivity and Depth of Microbial Plugging in Berea Sandstone Cores, J. Indust. Microbial., (1986) 195-203.

Raiders, R.A., T.F. Maher, R.M. Knapp, and M.J. McInerney, 1986b. Selective Plugging and Oil Displacement in Crossflow Core Systems by Microorganisms, paper SPE 15600 presented at the 61st Annual Meeting of the Society of Petroleum Enginers of AIME, New Orleans, LA, Oct. 1986.

Stalkup, F.I., Jr. 1984. Miscible_Displacement, Monograph series, SPE, Richardson, TX.

Torbati, H.M., R.A. Raiders, E.C. Donaldson, M.J. McInerney, G.E. Jenneman, and R.M. Knapp. 1986. Effect of Microbial Growth and Pore Entrance Size Distribution in Sandstone Cores, J. Indist. Microbial., (1986) 227-234. 
Table 4.1. Values of permeability reduction factor (PRF), recovery factor (RF), and cumulative gas production $\left(G_{p}\right)$ for each treatment for Core $\mathrm{CO}$.

\begin{tabular}{|c|c|c|c|c|}
\hline Treatment & & $\underset{\%}{\mathrm{PRF}}$ & $\underset{\%}{\mathrm{RF}}$ & $\mathrm{G}_{\mathrm{p}}$ \\
\hline 0 & & 100.0 & 0.0 & 0.0 \\
\hline 1 & & 74.6 & 5.0 & 0.0 \\
\hline 2 & & 60.0 & 7.4 & 1.0 \\
\hline 3 & & 71.5 & 17.3 & 8.0 \\
\hline 4 & & 67.6 & 24.8 & 9.1 \\
\hline 5 & & 26.2 & 34.7 & 17.1 \\
\hline 6 & & 21.8 & 45.1 & 38.6 \\
\hline 7 & & 15.5 & 52.5 & 15.5 \\
\hline 8 & & 20.0 & 62.4 & 88.6 \\
\hline 9 & & 18.0 & 68.3 & 119.1 \\
\hline 10 & $!$ & 11.0 & 73.7 & 148.1 \\
\hline 11 & & 15.3 & 78.2 & 173.1 \\
\hline 12 & & 13.3 & 82.2 & 194.1 \\
\hline 13 & & 8.0 & 84.2 & 198.6 \\
\hline 14 & & 4.9 & 84.2 & \\
\hline
\end{tabular}

Table 4.2. Values of permeability reduction factor (PRF), recovery factor (RF), and cumulative gas production $\left(\mathrm{G}_{\mathrm{p}}\right)$ for each treatment for Core $\mathrm{C} 09$.

\begin{tabular}{cccc} 
Treatment & $\begin{array}{c}\text { PRF } \\
\%\end{array}$ & $\begin{array}{c}\text { RF } \\
\%\end{array}$ & \multicolumn{1}{c}{$\mathrm{G}_{\mathrm{p}}$} \\
& 100.0 & 0.0 & 0.0 \\
0 & 56.5 & 3.3 & 1.0 \\
1 & 71.7 & 6.7 & 8.0 \\
2 & 28.7 & 23.3 & 22.0 \\
3 & 26.4 & 40.0 & 53.0 \\
4 & 23.0 & 45.6 & 80.0 \\
5 & 19.8 & 50.0 & 88.0 \\
6 & 17.7 & 52.2 & 111.0 \\
7 & 15.5 & 53.9 & 135.0 \\
8 & & &
\end{tabular}


Table 4.3. Values of permeability reduction factor (PRF), recovery factor (RF), and cumulative gas production $\left(G_{p}\right)$ for each treatment for Core C10.

$\begin{array}{cccc}\text { Treatment } & \begin{array}{c}\text { PRF } \\ \%\end{array} & \begin{array}{c}\text { RF } \\ \%\end{array} & \begin{array}{c}\mathrm{G}_{\mathrm{p}} \\ \mathrm{ml}\end{array} \\ 0 & 100.0 & 0.0 & 0.0 \\ 1 & 49.0 & 0.1 & 0.1 \\ 2 & 30.9 & 0.1 & 0.1 \\ 3 & 13.8 & 0.1 & 0.1 \\ 4 & 12.8 & 0.1 & 0.1 \\ 5 & 10.6 & 0.1 & 0.3 \\ 6 & 10.6 & 0.1 & 0.3\end{array}$

Table 4.4. Values of permeability reduction factor (PRF), recovery factor (RF), and cumulative gas production $\left(\mathrm{G}_{\mathrm{p}}\right)$ for each treatment for Core $\mathrm{Cl} 1$.

\begin{tabular}{cccc} 
Treatment & $\begin{array}{c}\text { PRF } \\
\%\end{array}$ & $\begin{array}{c}\text { RF } \\
\%\end{array}$ & \multicolumn{1}{c}{$\mathrm{G}_{\mathrm{p}}$} \\
& 100.0 & 0.0 & 0.0 \\
0 & 78.0 & 0.0 & 1.0 \\
1 & 50.0 & 3.7 & 8.0 \\
2 & 24.3 & 3.7 & 22.0 \\
3 & 21.4 & 5.0 & 53.0 \\
4 & 20.0 & 6.8 & 80.0 \\
5 & 17.1 & 7.7 & 88.0 \\
6 & 15.7 & 8.7 & 111.0 \\
7 & 20.6 & 22.4 & 135.0 \\
8 & & &
\end{tabular}




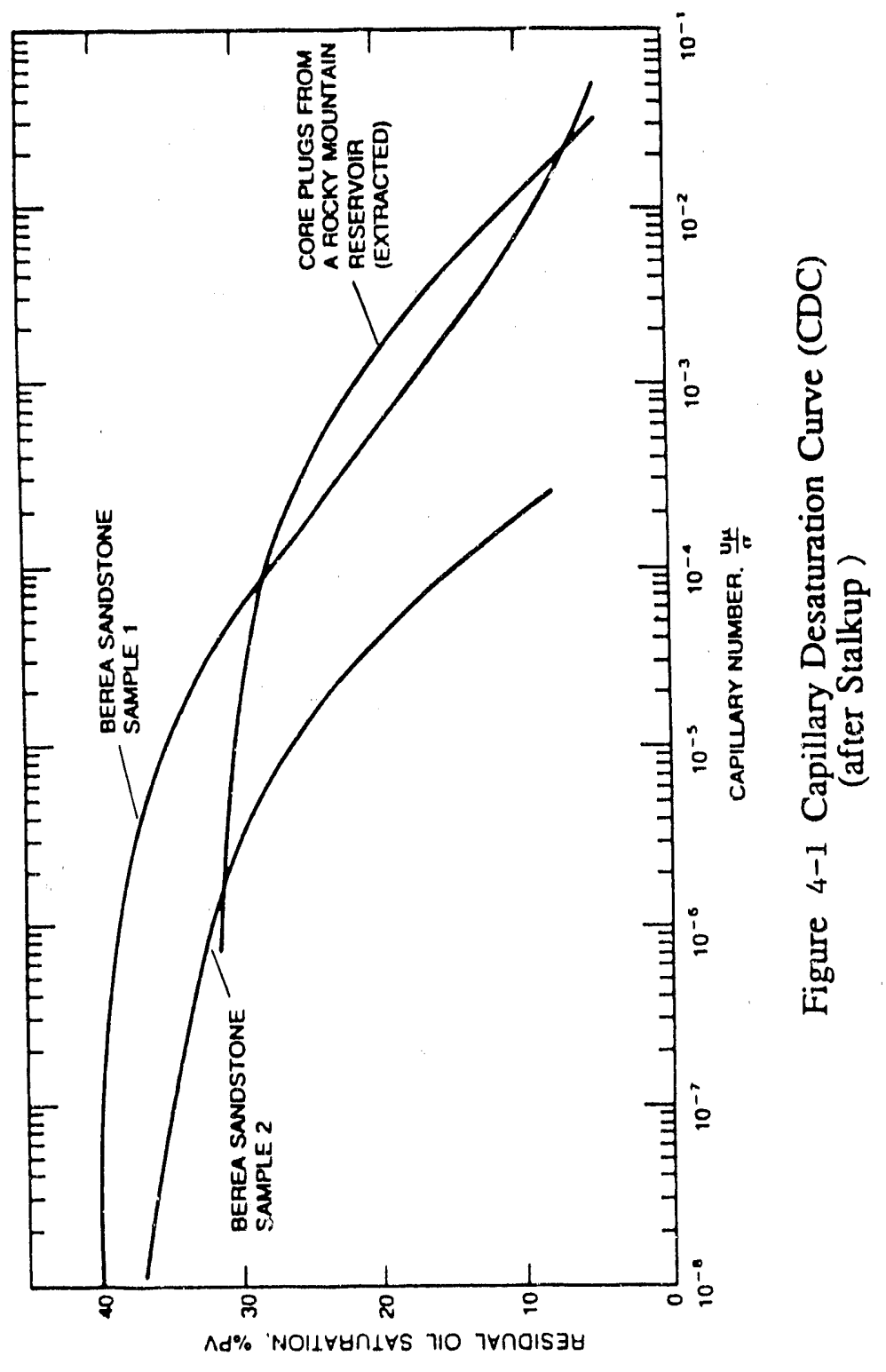




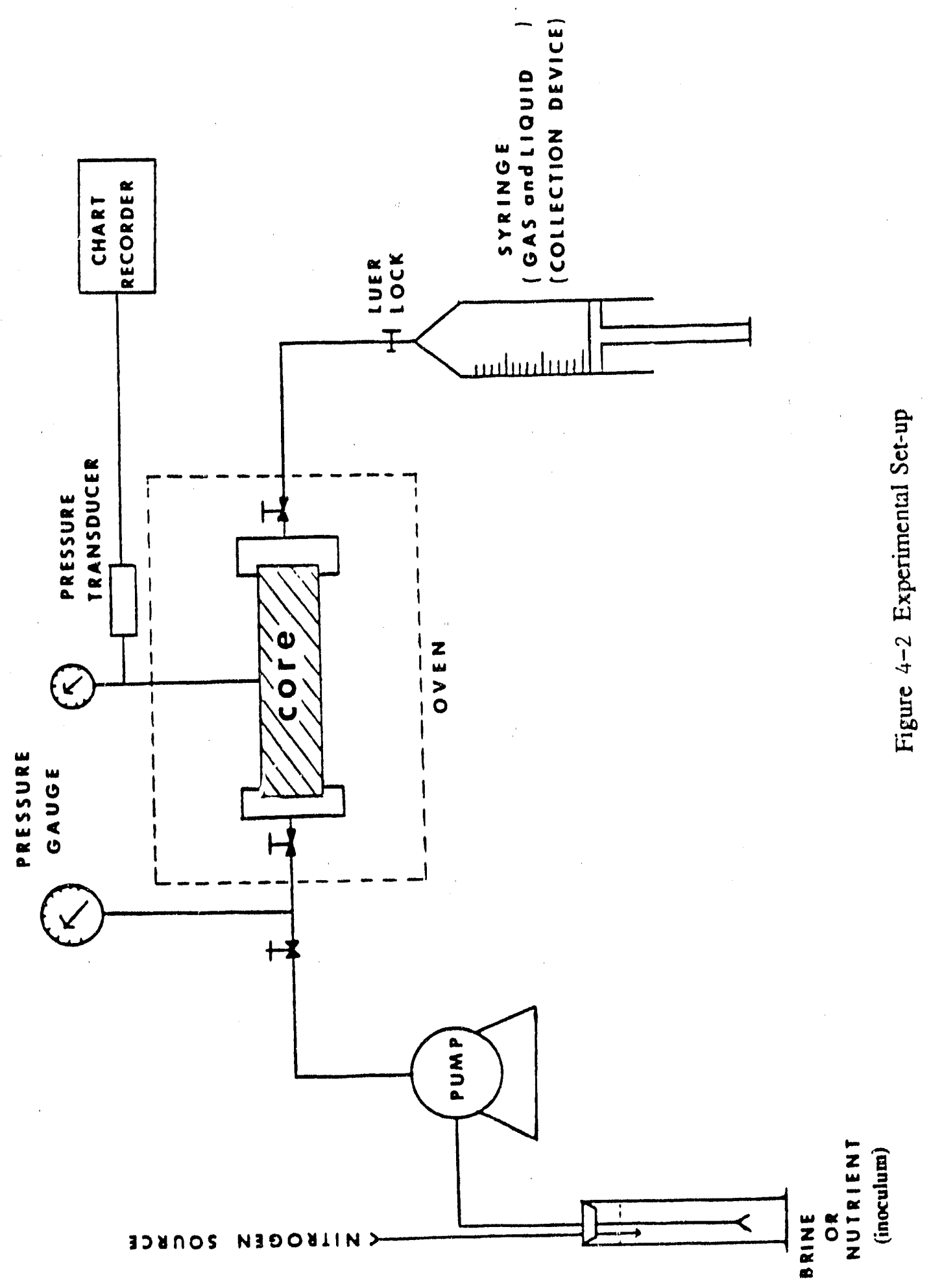




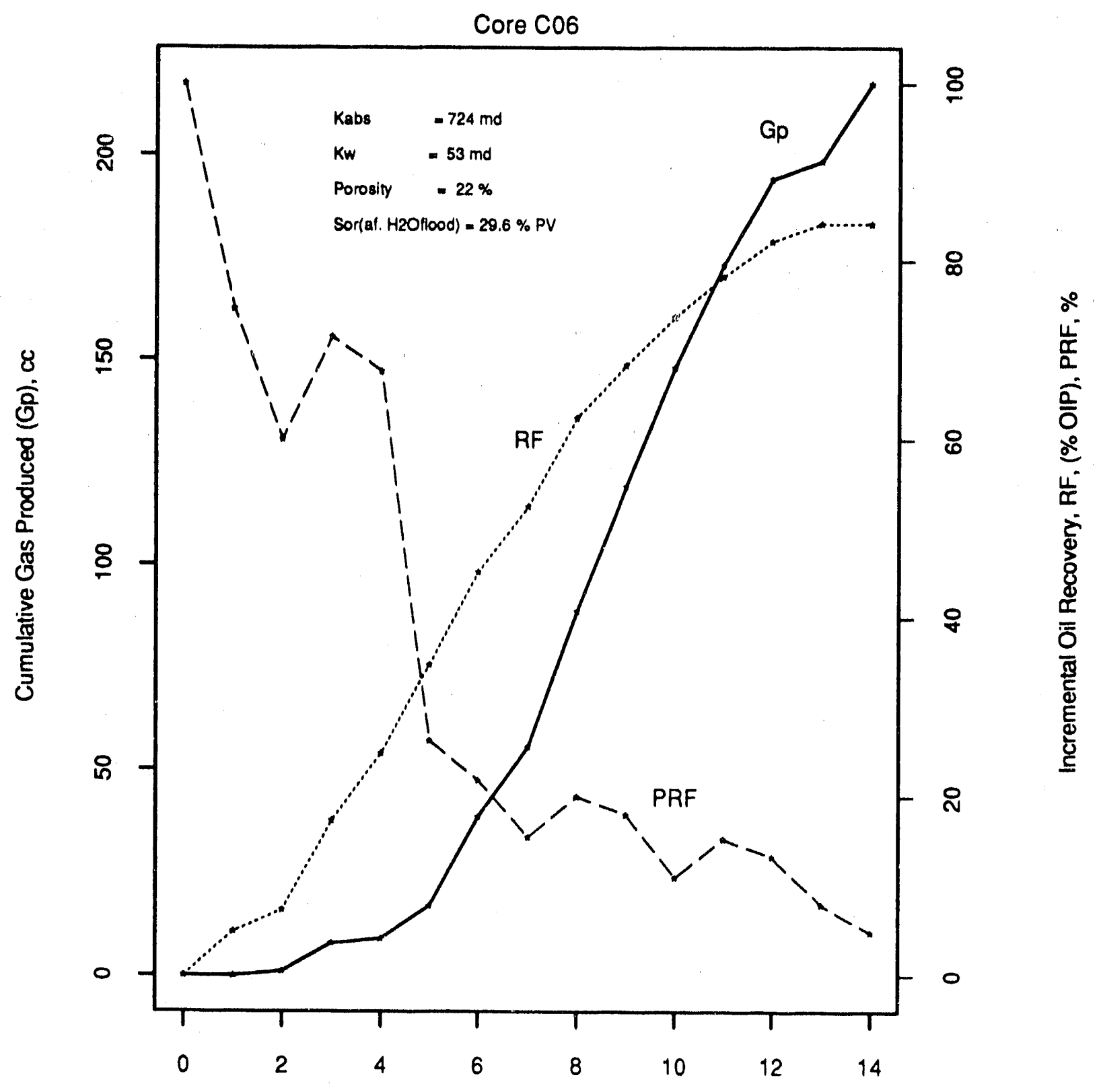

Number of Treatments

Figure 4-3. Effect of nutrient treatments on the permeability reduction facto (PRF), recovery factor (RF), and gas production (Gp). 


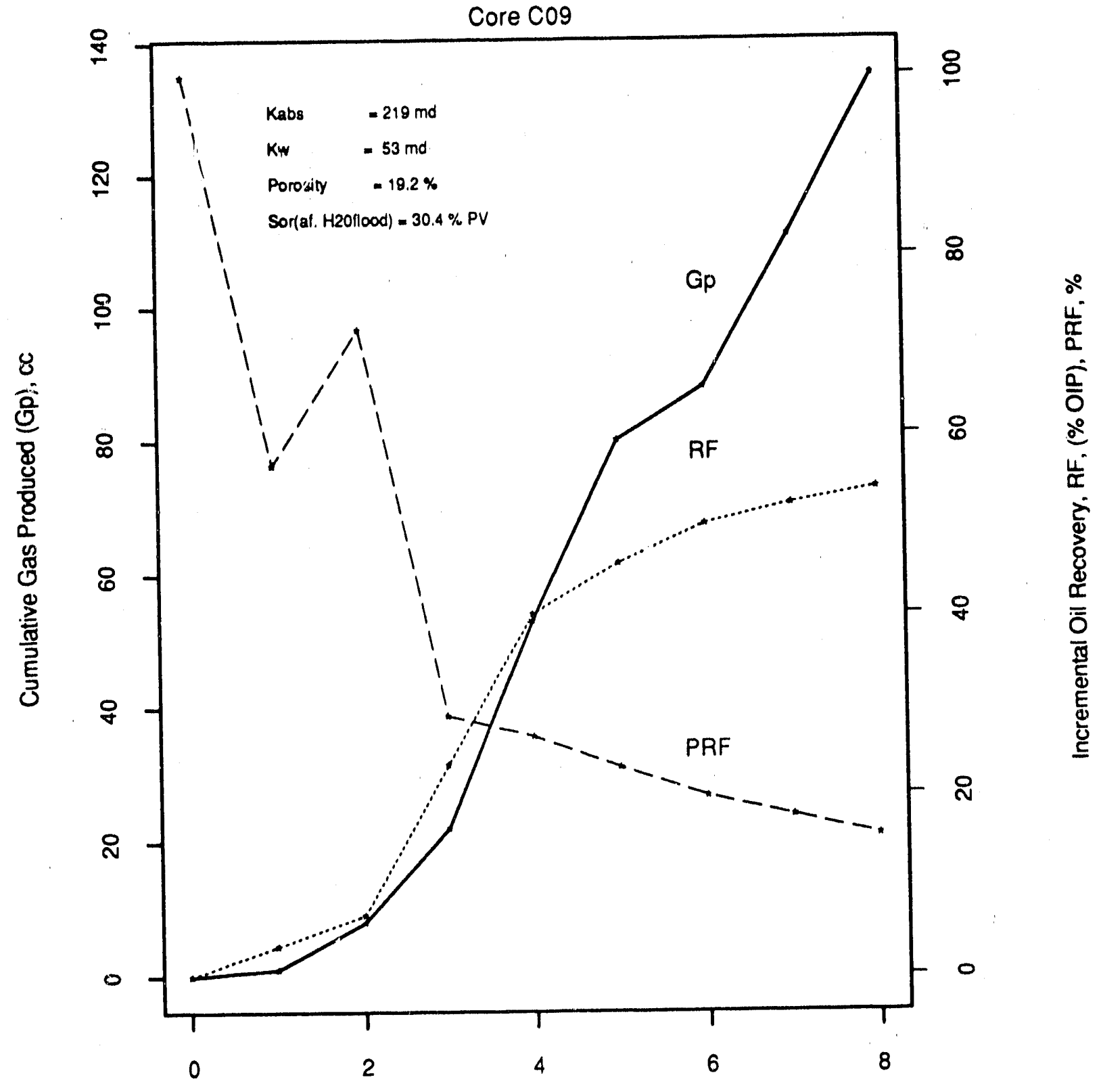

Number of Treatments

Figure 4-4. Effect of nutrient treatments on the permeability reduction factor (PRF), recovery factor (RF), and gas production (Gp). 


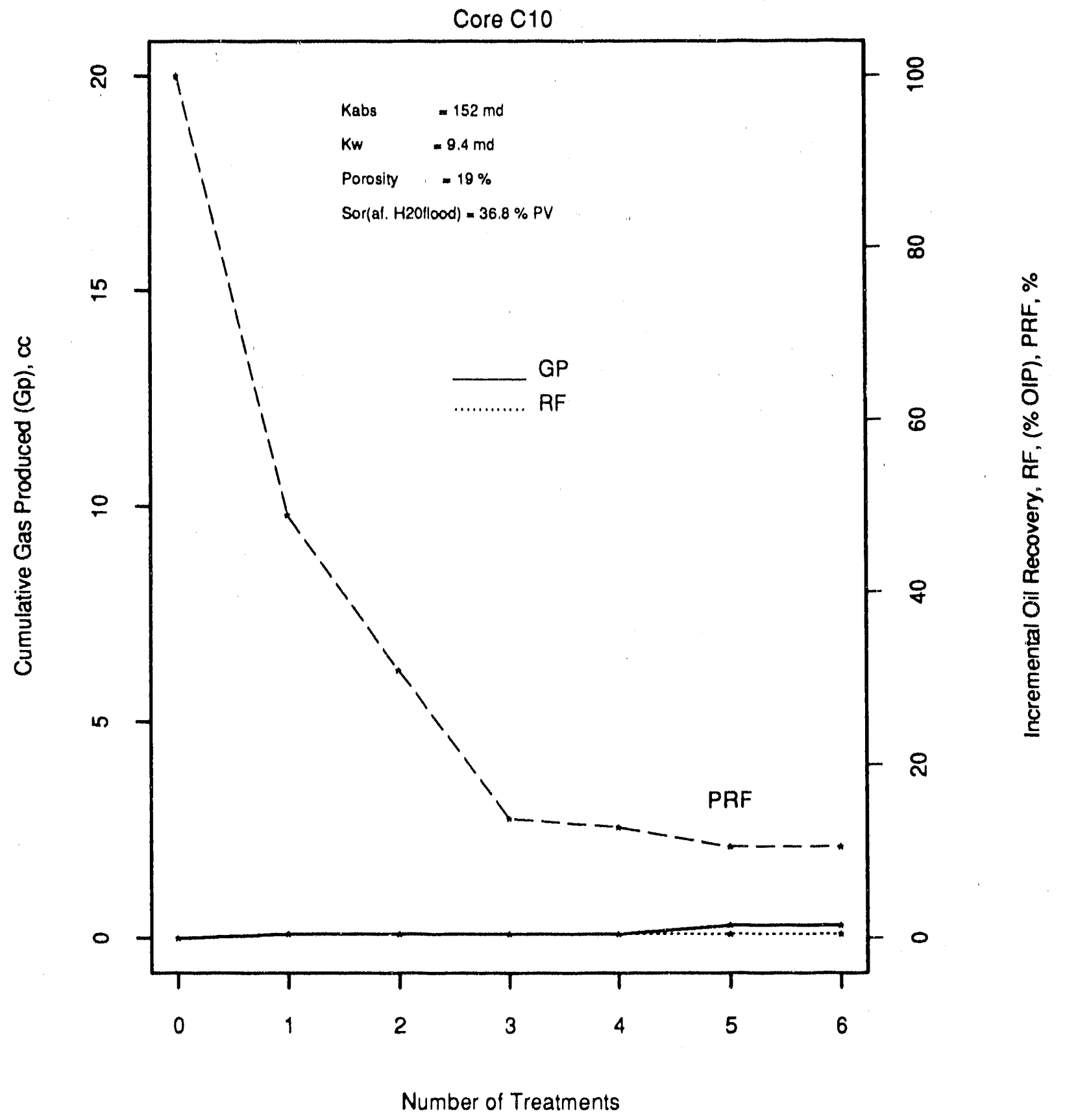

Figure 4-5. Effect of nutrient treatments on the permeability reduction factor (PRF), recovery factor (RF), and gas production (Gp). 


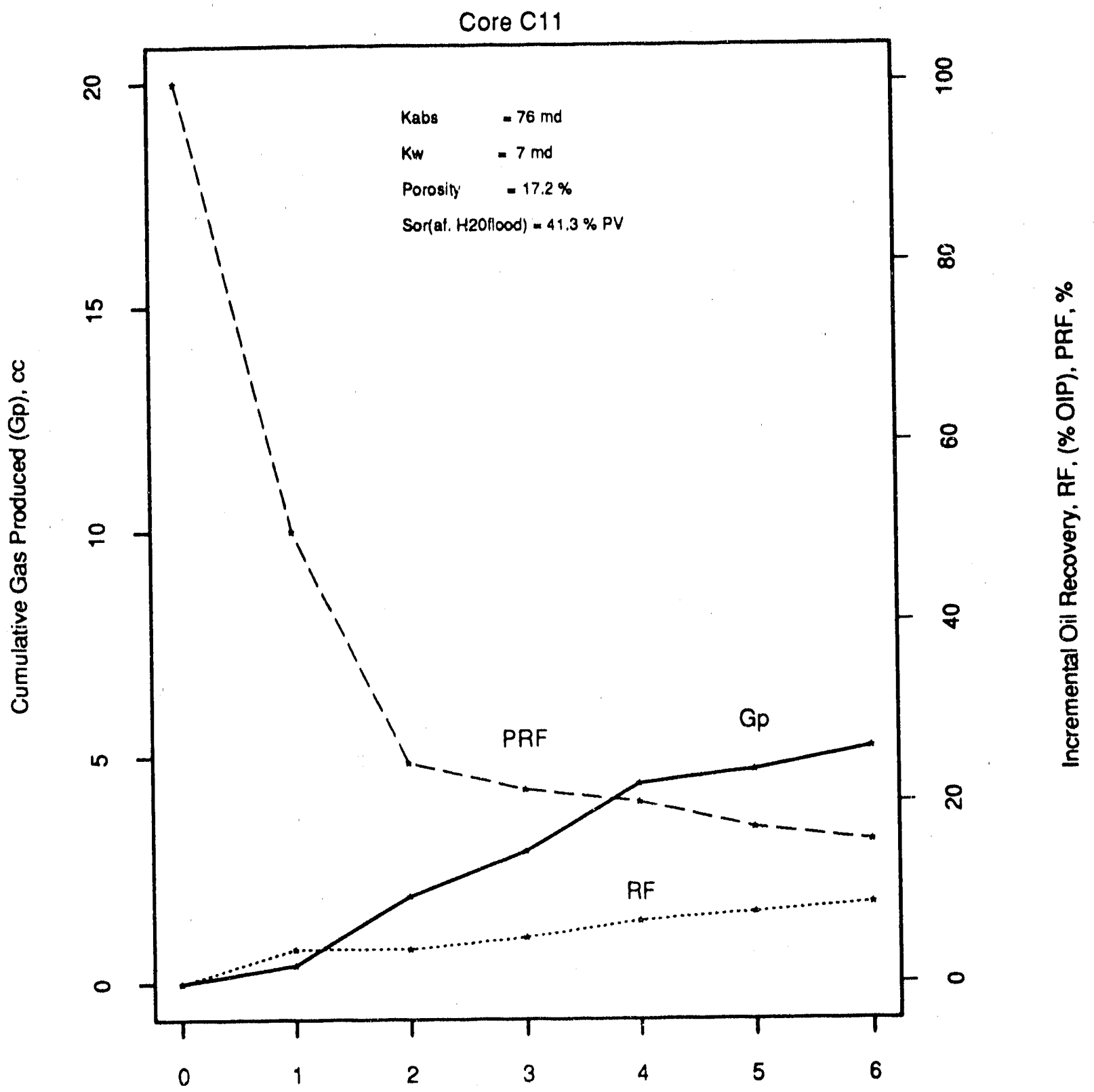

Number of Treatments

Figure 4-6. Effect of nutrient treatments on the permeability reduction factor (PRF), recovery factor (RF), and gas production (Gp). 


\section{Bacterial Movement And Activity In Porous Subsurface Formations}

\subsection{Introduction}

A detailed understanding of the mechanisms by which microorganisms penetrate subsurface formations is critical to the efficient and economical development of in situ microbially enhanced oil recovery technologies. Movement of bacteria through subsurface formations follows the movement of nutrients from septic tanks and leaking sewage pipes (Corapcioglu and Haridas, 1984). The enteric bacteria and viruses have been used to trace the movement of contaminated groundwater in much the same manner as chemical tracers are used (Keswick et al., 1982). Most of these studies are empirical in nature and have not addressed fundamental questions concerning the mechanisms of microbial movement. Such analyses are needed to evaluate and/or develop mathematical models which are required for the implementation of reservoir-wide processes.

In previous work, the biological factors important for transport of microorganisms through nutrient-saturated porous material under static conditions was studied (Reynolds et al., 1989). The penetration rates of a motile, non-chemotactic strain increased in a curvelinear fashion with the square of the core length, suggesting an ordered or band-like movement of cells through the core. According to this hypothesis, under conditions in which growth is restricted such as that in sand-packed corss, motile bacteria would consume practically all the locally available substrate, thereby creating a substrate gradient. Concomitantly, fermentation end products would accumulate and act as repellents. Both these conditions would stimulate the directional movement of the cells through the core. This mode of cell penetration and substrate utilization would resemble that found in plug-now reactors (Pfeffer, 1980).

In this study, the mode of transport of a motile strain of Escherichia coli RW262 through anaerobic, nutrient-saturated, static, unconsolidated porous media was investigated. The data show that motile cells move through the core in a band-like fashion. Further, substrate use and metabolite production by bacterial cells in sand-packed cores was determined. 


\subsection{Materials and Methods}

Bacterial strain and growth conditions : The motile, wild type strain of Escherichia coli RW262 ( $\mathrm{F}^{+}$mel-1 $\tan A \sup F 58 \lambda^{-}$) was kindly provided by F. Ziamain, Max Planck Institute for Molecular Biology, FRG. The strain was grown anaerobically in galactose-nitrate mineral medium (GNM) containing (per 100 $\mathrm{mL}$ ) : $0.45 \mathrm{~g}$ of galactose, $0.3 \mathrm{~g}$ of $\mathrm{NaNO}_{3}, 1.12 \mathrm{~g}$ of $\mathrm{K}_{2} \mathrm{HPO}_{4}, 0.48 \mathrm{~g}$ of $\mathrm{KH}_{2} \mathrm{PO}_{4}, 2 \mathrm{~mL}$ of Tanner's mineral solution' (Table 1.2), and $1 \mathrm{~mL}$ of Tanner's trace metal solution (Table 1.3). The $\mathrm{pH}$ of the medium was 7.0. The strain was maintained on slants of GNM with $2 \%$ ( $w / v o l$ ) agar and transferred every 15 days. After growth, the slants were stored at $4^{\circ} \mathrm{C}$. The motility of the strain was checked by inoculating MIO broth (Difco Laboratories).

Anaerobic media and solutions were prepared and used as described previously (Balch and Wolfe, 1976). The gas phase of all anaerobically prepared media and solutions was that of the anaerobic chamber, about 1 to $5 \% \mathrm{H}_{2}$ with the balance being $\mathrm{N}_{2}$. The cell densities in anaerobically incubated sand-packed cores and broths at $23^{\circ} \mathrm{C}$ were determined by viable cell count method. The counts were performed by serially diluting the sample in $20 \mathrm{mM}$ phosphate buffer ( $\mathrm{pH} 7.0$ ) and inoculating duplicate plates of Plate Count Agar (Difco Laboratories). Colonies were counted after aerobic incubation of plates for $24 \mathrm{~h}$ at $35^{\circ} \mathrm{C}$. The rate of growth of liquid cultures was also determined as the change in absorbance at 600 $\mathrm{nm}$ and the specific growth rate was calculated as described previously (McInemey et al., 1979).

Core experiments : Acid cleaned, commercially-available sand (100-to 200-mesh sire) saturated in GNM was used in prepare the anaerobic, sterile porous medium.

$\mathrm{cm})$ and plastic cores $(1.25$ by $10 \mathrm{~cm})$ were - r reviously (Reynolds et al., 1989). The cores wc. $d$ in a horizontal position inside the anaerobic chamber and inoculated with $0.2 \mathrm{ml}$ of mid-exponential phase culture. Duplicate cores were used for each treatment. The penetration rate of cells $\left(r_{p}\right)$, permeability $(k)$, and pore volume of 
each core were determined as described previously (Jenneman et al., 1985).

The plastic cores were marked at $2 \mathrm{~cm}$ interval, dividing each core into 5 sections. Each section was then cut by passing the core through a hot nichrome wire. The contents of each section were placed in $2 \mathrm{ml}$ of sterile phosphate buffer and mixed by vortexing for $1 \mathrm{~min}$. Similarly, the entire contents of glass cores were removed using $5 \mathrm{ml}$ of buffer. The liquid fraction was analyzed for the number of viable cells, substrate concentrations, and fermentation end products. The galactose concentration was measured enzymatically (Boehringer Manheim GmbH). The type and amount of short chain monocarboxylic fatty acids was determined by high pressure liquid chromatography using an ion exclusion column (Amos and Mclnemey, 1989).

\subsection{Results}

Penetration rate of the cells : E.coli RW262 penetrated nutrient-saturated, sand-packed cores (both glass and plastic) at a rate of $0.4 \mathrm{~cm} / \mathrm{h}$. The pore volume of $10-\mathrm{cm}$ long, plastic cores was $6 \mathrm{ml}$. The distribution of the pore liquid was such that the two end sections had pore volumes of $1.5 \mathrm{ml}$ each while the middle three sections had pore volumes of $1.0 \mathrm{ml}$ each. Two $\mathrm{ml}$ of buffer was used to wash out the contents of each section. This resulted in a 1:2 dilution in the contents of three middle sections and one to one and a third dilution of the contents of the two end sections. The pore volume of $8 \mathrm{~cm}$ long glass cores was $5 \mathrm{ml}$ and a dilution of $1: 1$ was obtained when $5 \mathrm{ml}$ of buffer was used to extract the contents of the core. The permeability $(\mathbf{k})$ of both the glass and plastic cores ranged from 7- to 7.5 Darcies .

Growth rates in broth versus porous medium : The culture used for inoculation of the cores was in the exponential phase of growth and had a cell concentration of $2 \times 10^{5}$ cells $/ \mathrm{mL}$. Since $0.1 \mathrm{ml}$ of this culture was inoculated into each $8 \mathrm{~cm}$ long glass cores, the initial cell density used to inoculate the cores was $2 \times 10^{4}$ cells $/ \mathrm{ml}$. Immediately after the inoculation, $3.0 \times 10^{4}$ cells $/ \mathrm{mL}$ were recovered, indicating that the cells did not adsorb to the sand grains. The cell concentration in duplicate cores was determined at $6,10.5,15,20,35$, and $41.5 \mathrm{~h}$ of incubation. Figure 5.1 
shows that the cell population inside the core increased exponentially with a doubling time of 2 h (specific growth rate of 0.35 ). However, under similar experimental conditions, the doubling time of this strain in GNM broth was $1 \mathrm{~h}$ (specific growth rate of 0.69 ). Further, the lag-phase in porous media was $6 \mathrm{~h}$ compared to $2.5 \mathrm{~h}$ in broth. This suggest that the growth of the strain was restricted in sand-packed cores.

Figure 5.2 shows the change in the concentration of substrates and products in cores at different time intervals. After $41.5 \mathrm{~h}$ of incubation, $4.8 \mathrm{mM}$ galactose was consumed and $7.4 \mathrm{mM}$ acetate was produced by strain RW262 inside the core. Acetate was the only fermentation acid detected in the cores. Surprisingly, no melabolic activity, as evidenced by galactose consumption or acetate production, was detected till $20 \mathrm{~h}$ of incubation even though the cell density increased from $3 \mathrm{x}$ $10^{4}$ cell $/ \mathrm{mL}$ to $4 \times 10^{6}$ cells $/ \mathrm{mL}$ ( Fig. 5.1 ). Similarly, in liquid culture, $3.6 \mathrm{mM}$ acetate was formed after a 3 -fold increase in cell concentration. However, it is possible that a small amount of galactose was used which would not be detected by our assay. Another possibility was that the sand contained organic compounds which could support growth. However, when galactose was deleted from the medium used to saturate the cores, no change in cell numbers was observed. Thus, it appears that if cell densities are low $\left(<10^{7}\right.$ cells $\left./ \mathrm{mL}\right)$, small amounts of substrate will support a large increase in the cell population .

Mechanism of cell propagation through porous medium : Figure 5.3 shows how cells moved through the core. After six hours, viable cells were detected in only the front two sections of the cores. With continued incubation, the presence of viable cells was sequentially detected in the remaining sections. As the cells propagated through the core, high cell concentrations were detected in each new section. This indicated that the cells were moving in a band-like fashion rather than dispersing through the core in a random manner.

The concentration of acetate (Fig. 5.4) and galactose (Fig.5.5) were determined in different sections of the core with time. The increase in acetate concentration in the first section during the first $15 \mathrm{~h}$ of incubation showed that most of the metabolic activity occured in this section. This is also where the highest cell 
concentrations were observed (Fig.5.3). After 25 b of incubation, active mctabolism, as evidenced by acetate production, was sequentially observed in the other sections of the core. Interestingly, the data showed that cell propagation proceeded the depletion of galactose or an accumulation of large amounts of acetate in a section. Thus, the cells were migrating before a substrate gradient had been generated.

\subsection{Discussion}

Methods have been developed to determine the in situ growth and metabolism of microorganisms in subsurface materials. Analyses showed that E.coli grew at a slower rate in porous material compared to its rate of growth in liquid medium under identical experimental conditions. This shows that growth was restricted by the smaller pore spaces found in subsurface materials. The metabolism of galactose by $E$. coli was not altered. Galactose was fermented primarily to acetate when $E$. coli was grown in liquid culture or in sand-packed cores. Interestingly, over a 2-fold increase in cell concentration was observed before a significant change in galactose concentration was detected. This suggests that the cells are very efficient in converting small amounts of substrate into cellular material .

The concentration of cells in different sections of the core was determined with time. These data showed that cells propagated through the core in an ordered rather than andom fashion. Large amounts of galactose were detected in all core sections up to $34 \mathrm{~h}$ of incubation. Breakthrough of the cells occured within about $25 \mathrm{~h}$ of incubation. Thus, the movement of cells did not occur in response to limiting substrate concentrations .

This work shows that we can accurately determine the primary dependent variables needed to access the accuracy of mathematical models. We will also be able to determine the efficiency of growth and nutrient utilization by microorganisms in porous material. These data are needed to calculate the amounts of nutrients and time required for microbially enhanced oil recvory processes. 


\subsection{Conclusions}

a. Methods have been developed to accurately determine the primary dependent variables needed to access the accuracy of mathematical models.

b. E.coli grew at a slower rate in porous medium compared to its rate of growth in liquid medium under indentical experimental conditions.

c. The metabolism of galactose by E.coli was not altered in the porous medium. Galactose was fermented primarily to acetate when E.coli was grown in liquid culture or in sand-packed cores. d. The bacterial cells moved and grew throughout the available pore volume in an ordered rather than random fashion.

e. The breakthrough of cells occured before appreciable consumption of galactose or accumulation of acetate. 


\section{References}

Amos, D.A., and M. J. McInerney, 1989. Poly-B-hydroxyalkanoate in Syntrophomonas wolfie. Arch. Microbiol. 152: 172-177

Balch, W. E., and R. S. Wolfe. 1976. New approach to the cultivation of methanogenic bacteria:2-mercaptoethanesulfonic acid (HS-CoM)- dependent growth of Methanobacterium ruminantium in a pressurized atmosphere. Appl. Environ. Microbiol. 32:781-791

Coraoiciogla, M.Y., and A. Haridas. 1984. Transport and fate of microorganisms in porous media : a theoretical investigation. J.Hydrol. (Wellington North) 72:149-169

Keswick, B. H., D. S. Wang, and C. P. Gerba.1982. The use of microorganisms as groundwater tracers : a review. Ground Water, 20:142-149

Jenneman, G. E., M. J. McInemey, and R. M. Knapp.1985.Microbial penetration through nutrient-saturated Berea sand-stone. Appl. Environ. Microbiol. $50: 383-391$

McInerney, M. J., M. P. Bryant, and N. Pfening. 1979. Anaerobic bacterium that degrades fatty acids in syntrophic association with methanogens. Arch. Microbiol. 122:129-135.

Pfefier, J. T. 1980. Anaerobic digestion processes, p. 187-203. In D. A. Stafford, B. I. Wheatley, and D. E. Hughes (ed.) Anaerobic Digestion. Applied Sciences Publishers Ltd. , London.

Reynolds, P. J., P. Sharma, G. E. Jenneman,and M. J. McInerney. 1989. Mechanisms of Microbial Movement in Subsurface Materials. Appl. Environ. Microbiol. 55:2280-2286 


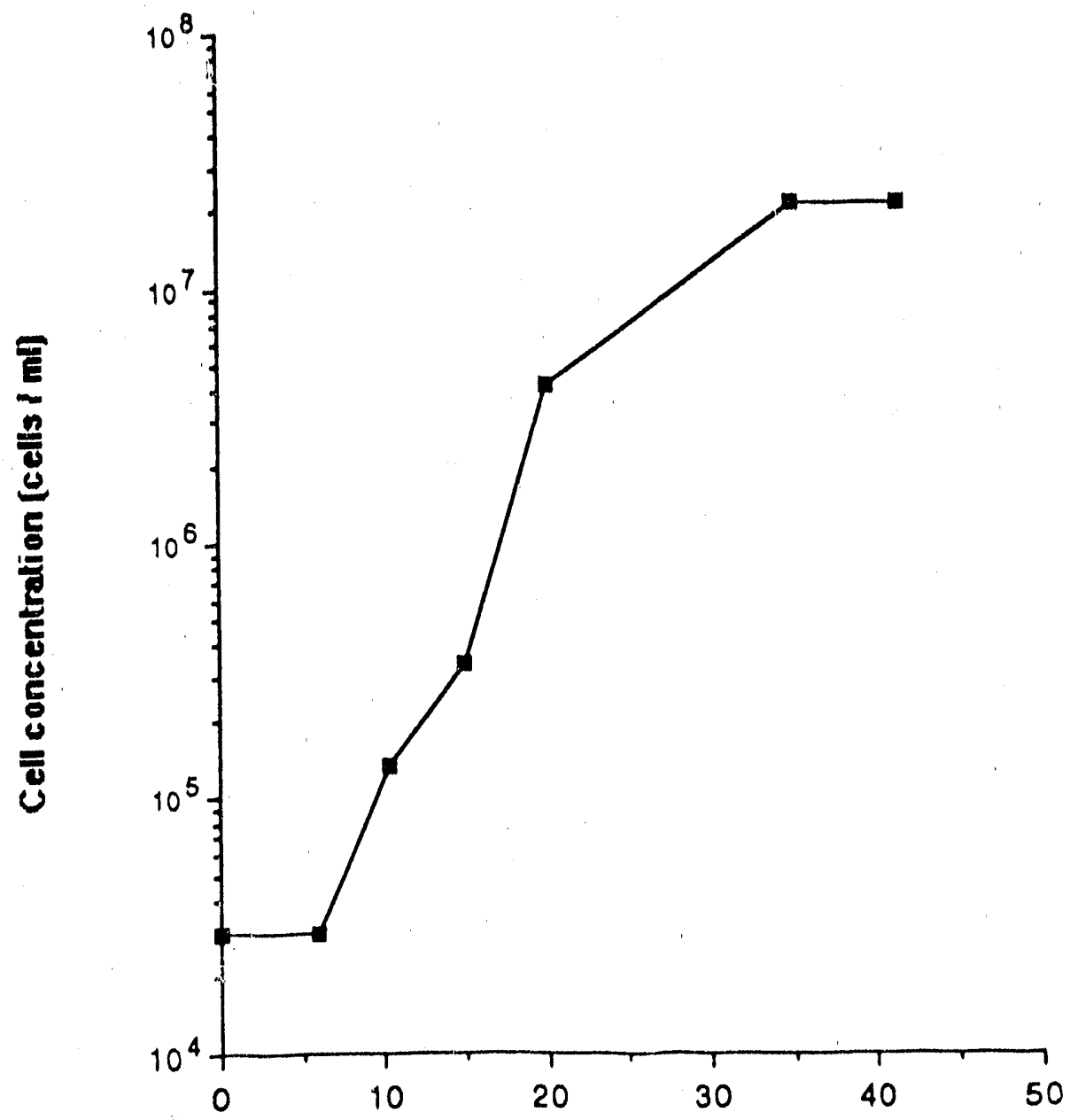

Time (h)

Figure 5.1. Growth of $E$. coli RW262 in nutrient-saturated, sand-packed cores . At each time interval, the entire contents of a $8 \mathrm{~cm}$-long sand-packed cores were removed and the cell concentration was determined. Values are means of duplicate cores. 


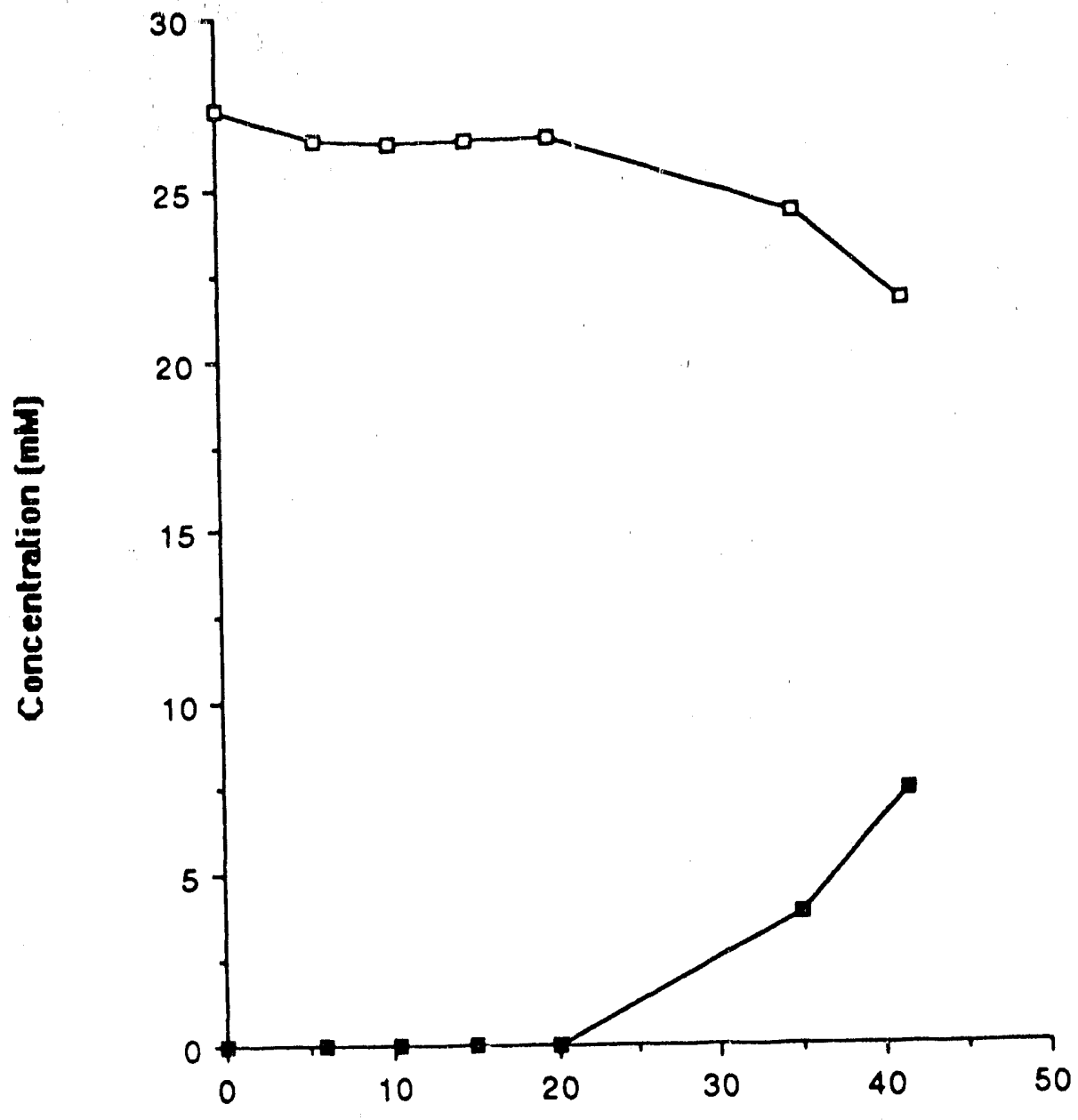

Time (h)

Figure 5. 2. Change in galactose (open square) and acetate (closed square) in nutrient-saturated, sand-packed cores. The concentrations of these compounds were determined from the contents of cores used in Figure 1. 


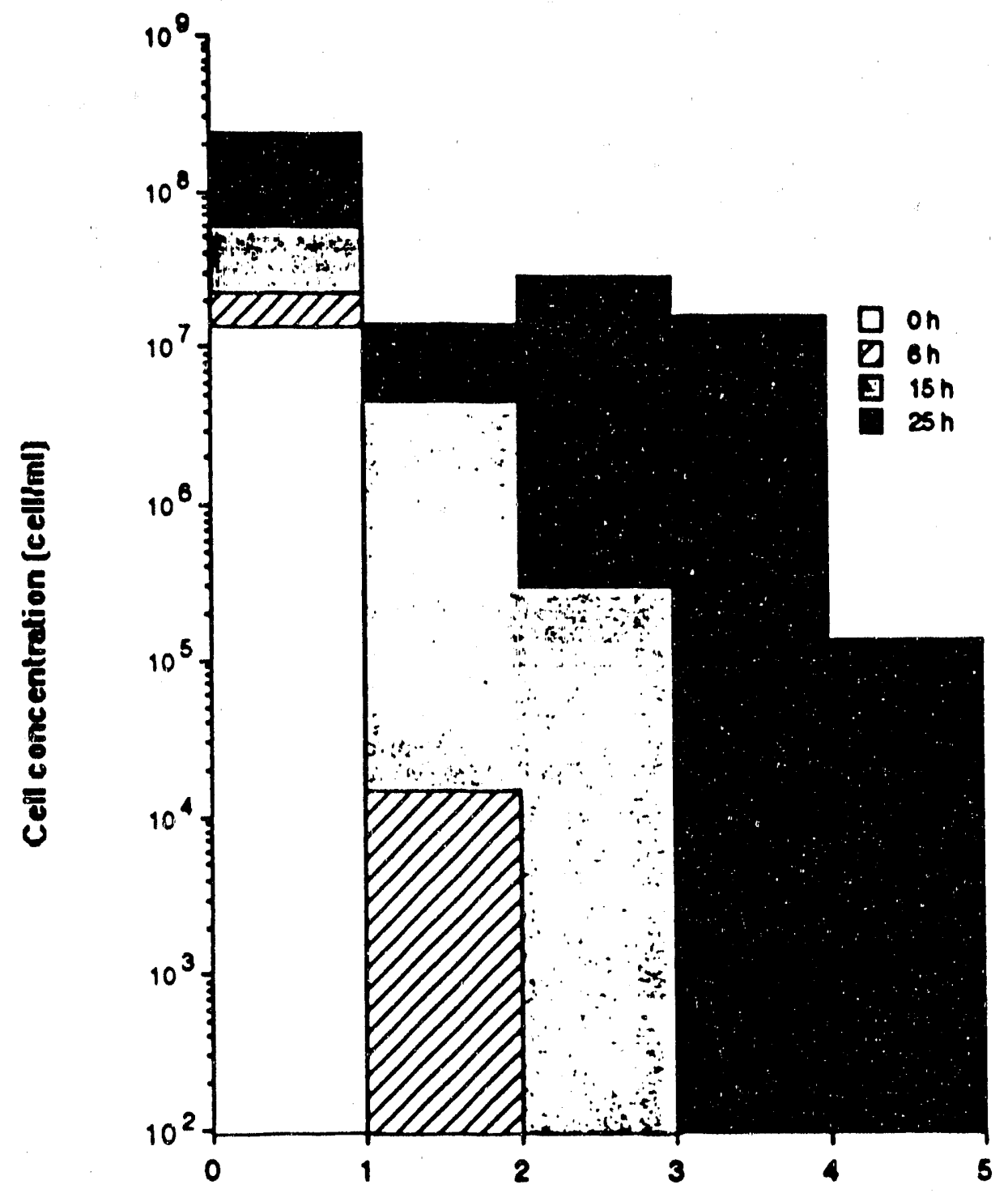

Section number

Figure 5. 3. Propagation of cells through sand packed cores . Duplicate $10 \mathrm{~cm}$-long plastic cores were cut into 5 sections of equal length. The contents were removed and numbers of viable cells were determined. The detection limit was $300 \mathrm{cells} / \mathrm{ml}$. 


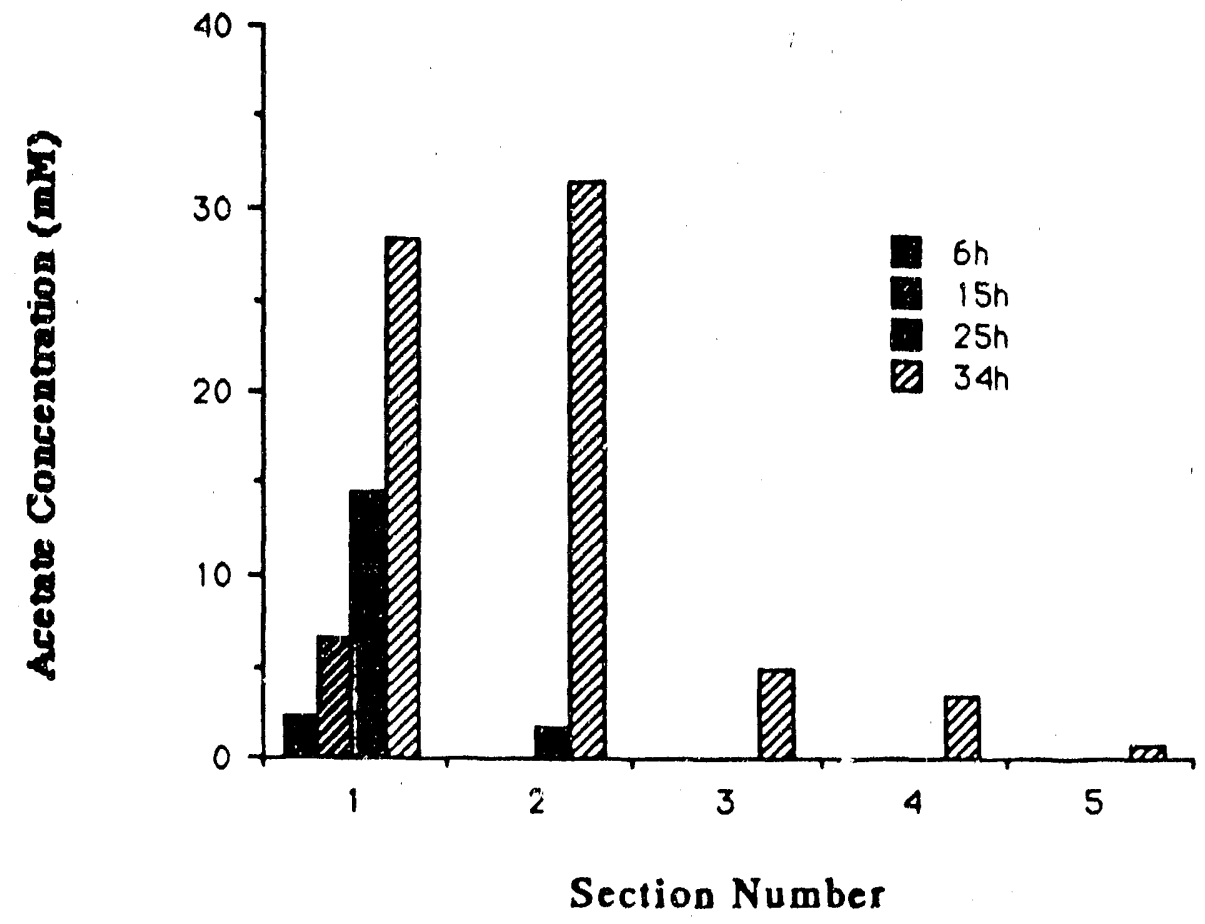

Figure 5.4. Change in acetate concentration with time in different sections of the core. The concentration of acetate in each section obtained from the cores used in Figure 3 were determined. 


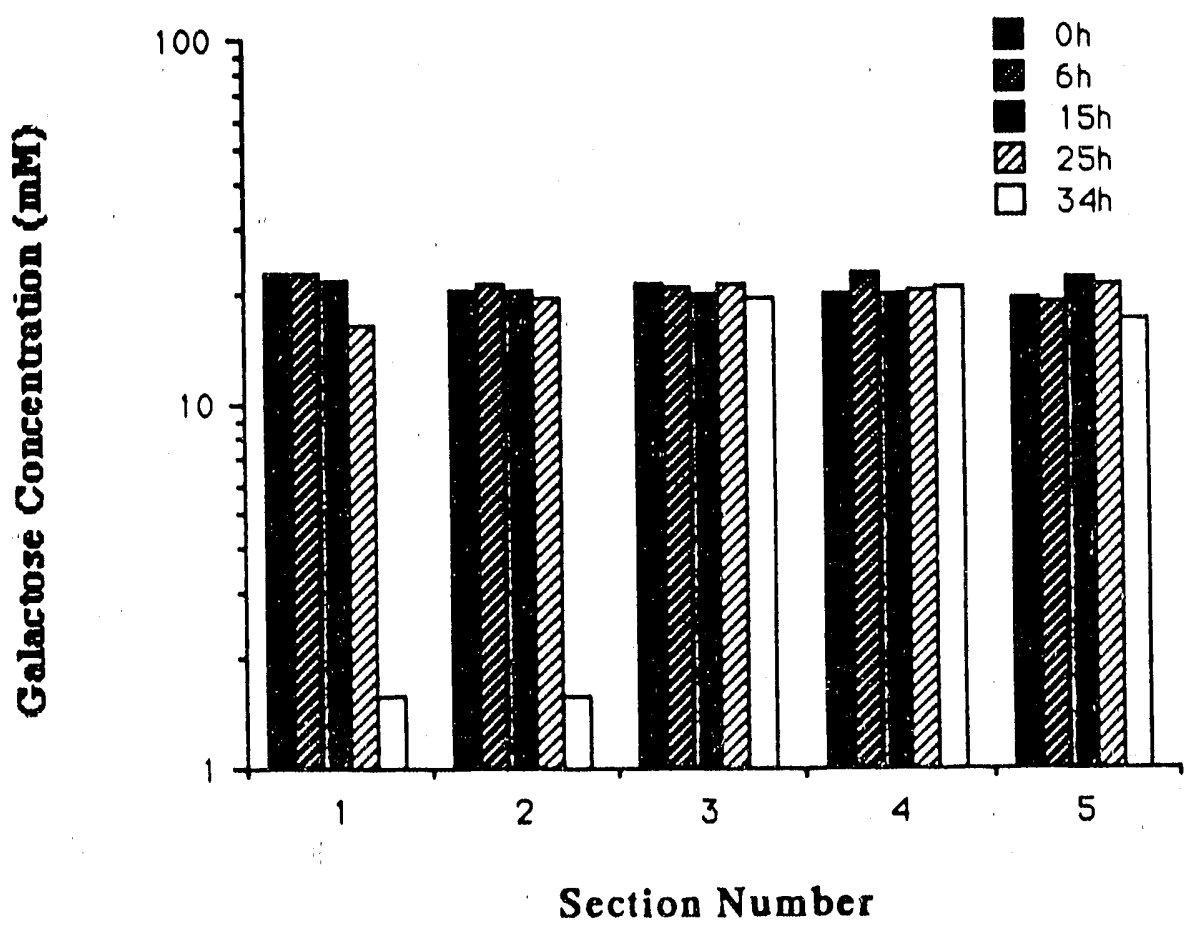

Figure 5.5. Change in galactose concentartion with time in the different sections of the core . See legends of Figure 3 and 4 for details . 


\section{MATHEMATICAL MODELLING OF MEOR PROCESS}

\subsection{Introduction}

Several selective plugging techniques have been developed [Breston, 1957] to modify permeability variations which detrimentally influence oil recovery efficiency. Unfortunately, their success is limited in stratified reservoirs. However, a microbiological approach to enhancement of oil recovery (MEOR), as an emerging technology, seems superior in many respects.

Many experimental studies [Jang, et al.,1984, Jenneman, et al., 1988, Jenneman,, et al., 1984] have been conducted to investigate MEOR processes including (1) the transportation of viable bacteria and nutrients into high permeability regions of the reservoir, (2) the in situ growth and metabolism in porous media; (3) effects of bioproducts on MEOR processes.

Associated with laboratory work, mathernatical simulation has been introduced [Knapp, et al., 1988] to help understand mechanisms involved in MEOR processes. With application of physical principles from fluid dynamics and microbial process kinetics, mathematical modelling of MEOR processes are characterized by a transportdispersion-metabolism phenomena.

This study, based on the previous work [Knapp, et al., 1988], is aimed at investigating the quantitative relationships among the species involved in the MEOR process and the permeabilty reduction as a result of this process. A three-phase, seven-species, one-dimension model is proposed. The model is specified into three categories according to the different mechanisms and flow patterns among the injection, incubation, and continued-injection processes forming a typical experimental treatment. Third-order 
upwinding convective differencing scheme is adopted as a solution technique highly resistant to numerical dispersion and oscillation. Varying time step sizes implemented in computation of incubation process leads to effective enhancement of simulator efficiency.

The model was simplified to a one-phase system to simulate batchfermentation. Numerical solutions are presented to show quantitative relationship among species during metabolism.

\subsection{Microbial Activities}

Materials used in a parallel experimental study are bacteria $\left(\mathrm{CH}_{1.8} \mathrm{O}_{0.5} \mathrm{~N}_{0.2}\right)$, glucose $\left(\mathrm{C}_{6} \mathrm{H}_{12} \mathrm{O}_{6}\right)$, and ammonium nitrate $\left(\mathrm{NH}_{4} \mathrm{NO}_{3}\right)$. There are two types of basic reactions involved in the experiments. One is anaerobic cell growth and netabolism by consumption of both glucose (carbon source) and ammonium (nitrogen source) [Bu'lock and Kristiansen,1984]:

$$
\mathrm{C}_{6} \mathrm{H}_{12} \mathrm{O}_{6}+1.2 \mathrm{NH}_{4}^{+} \rightarrow 6 \mathrm{CH}_{1.8} \mathrm{O}_{0.5} \mathrm{~N}_{0.2}+3 \mathrm{H}_{2} \mathrm{O}
$$

Another is growth-associated production of acetate $\left(\mathrm{CH}_{3} \mathrm{COO}^{-}\right)$, carbon dioxide $\left(\mathrm{CO}_{2}\right)$, and nitrogen $\left(\mathrm{N}_{2}\right)$ :

$$
5 \mathrm{C}_{6} \mathrm{H}_{12} \mathrm{O}_{6}+8 \mathrm{NO}_{3}^{-} \rightarrow 10 \mathrm{CH}_{3} \mathrm{COO}^{-}+10 \mathrm{CO}_{2}+4 \mathrm{~N}_{2}+14 \mathrm{H}_{2} \mathrm{O}+2 \mathrm{H}^{+}
$$

There are six species primarily involved in microbial activities: glucose $\left(\mathrm{C}_{6} \mathrm{H}_{12} \mathrm{O}_{6}\right)$, ammonium nitrate $\left(\mathrm{NH}_{4} \mathrm{NO}_{3}\right)$, biomass $\left(\mathrm{CH}_{1.8} \mathrm{O}_{0.5} \mathrm{~N}_{0.2}\right)$, acetate 
$\left(\mathrm{CH}_{3} \mathrm{COO}^{-}\right)$, carbon dioxide $\left(\mathrm{CO}_{2}\right)$, and nitrogen $\left(\mathrm{N}_{2}\right)$. However, since ammonium nitrate is separated into (1) ammonium serving as the nitrogen source for metabolism and (2) nitrate which is reduced to $\mathrm{N}_{2}$, seven species actually go into the microbial reactions. These species, as independent variables, can be quantitatively described by appropriate mathematical formula except for $\mathrm{CO}_{2}$, which can be estimated from the production of acetate according to the chemical balance described by Eq (6.2).

\section{Assumptions}

A set of fundamental assumptions were made to develope the model equations.

1. One-dimensional, horizontal, and linear flow. Gravity is ignored.

2. Homogeneous, isotropic, and incompressible porous medium.

3. Three-phase and Newtonian fluids: oil, water, and gas.

4. Isothermal processes are assumed for microbial transport, growth, and metabolism.

5. Both glucose and ammonium nitrate are limited.

6. Bacteria in the core are divided into cells suspended in the flowing water phase and a sessile phase composed of the cells retained on the pore surfaces.

7. Nutrients suspended in the flowing phase are assumed to fully penetrate and saturate the sessile phase so that anaerobic microbial growth and metabolism occur in the same fashion in both flowing water and sessile phases.

8. The seven species involved in metabolism are glucose (substrate 1), ammonium (positive-ion part of substrate 2), nitrate (negative-ion part of substrate 2), biomass (product 1), acetate (product 2), carbon dioxide (product 3), and nitrogen (product 4). 


\subsection{Model Equations}

\section{Conservation Equations for Species}

The transport of each species suspended in the flowing water phase is governed by a typical convection-dispersion equation:

$$
\frac{\partial\left(\phi C_{i}\right)}{\partial t}=-\frac{\partial\left(u_{f} C_{i}\right)}{\partial x}+\frac{\partial}{\partial x}\left(\phi K_{D} \frac{\partial C_{i}}{\partial x}\right)
$$

where, $u_{f}$ is Darcy flux, $K_{D}$ is dispersion coefficient, $\phi$ is updated porosity, $R_{i}$ is rate of generation or consumption of individual species.

Eq (6.3) is individually applied to species such as acetate (A), biomass (B), $\mathrm{N}_{2}$ $(\mathrm{N})$, glucose $(\mathrm{S} 1)$, ammonium $\left(\mathrm{S2}^{+}\right)$, and nitrate $\left(\mathrm{S2}^{-}\right)$. However, the production of $\mathrm{CO}_{2}$ (C) can be estimated according to acetate generation:

$$
\frac{\partial \mathrm{C}_{\mathrm{C}}}{\partial \mathrm{t}}=\omega \frac{\partial \mathrm{C}_{\mathrm{A}}}{\partial \mathrm{t}}, \quad \omega=\frac{(\mathrm{MW})_{\mathrm{C}}}{(\mathrm{MW})_{\mathrm{A}}}
$$

where, $\mathrm{C}_{\mathrm{C}}$ and $\mathrm{C}_{\mathrm{A}}$ are respectively concentrations for $\mathrm{CO}_{2}$ and acetate, $(\mathrm{MW})_{\mathrm{C}}$ and $(\mathrm{MW})_{\mathrm{A}}$ are molecular weights for $\mathrm{CO}_{2}$ and acetate, respectively.

The accumulation of biomass attached to the pore surfaces is assumed to be the net result of biomass retention, detachment, and growth:

$$
\frac{\partial}{\partial t}\left(\rho_{B} \sigma\right)=R_{I}-R_{d}+R_{B s}
$$

where, $R_{r}, R_{d}$, and $R_{B s}$ are rates for retention, detachment, and growth, respectively, $\rho_{B}$ 
is the density of biomass, and $\sigma$ is the fraction of pore space occupied by retained cells.

\section{Rate Equations for Species}

The biomass retention rate is considered to be proportional to the biomass $u_{f} C_{B}$ entering a given area and to the applicable plugging capacity $(1-\sigma) \rho_{B}$ of the porous medium [Cernansky and Siroky, 1985]:

$$
R_{T}=K_{T}\left(u_{f} C_{B}\right)(1-\sigma) \rho_{B}
$$

where, $K_{r}$ is the kinetic coefficient of retention, $u_{f}$ is the Darcy flux, $C_{B}$ is the mass concentration of biomass in the flowing phase, and $\sigma$ is the updated volume fraction of the sessile phase.

The biomass detachment rate is a function of the biomass $\left(\sigma \rho_{B}\right)$ attached on the pore surfaces and the shear force $\left(\mu_{r} \frac{\mu_{w}}{K}\right)$ between the stream of the suspension and the retained cell bodies [Cernansky and Siroky, 1985]:

$$
R_{d}=K_{d}\left(\sigma \rho_{B}\right) u_{r} \frac{\mu_{w}}{K}
$$

where, $K_{d}$ is the kinetic coefficient of detachment, $K$ is the updated permeability, which is defined as:

$$
\mathrm{K}_{\mathrm{f}}=\mathrm{K}_{0}\left(\frac{\phi}{\phi_{0}}\right)^{3}, \quad \quad \phi=\phi_{0}(1-\sigma)
$$


where, $\mathrm{K}_{0}$ and $\phi_{0}$ are respectively initial permeability and porosity.

The growth rate $R_{B s}$ for retained biomass, limited by availability of the two substrates (glucose and ammonium nitrate), can be easily written [Bu'lock and Kristiansen, 1984]:

$$
R_{\mathrm{Bs}}=u_{m, B} \frac{C_{S 1}}{K_{B / S 1}+C_{S 1}} \frac{C_{S 2^{+}}}{K_{B / S 2^{+}}+C_{S 2^{+}}}\left(\sigma \rho_{B}\right)
$$

where, $\mathrm{C}_{\mathrm{S} 1}$ and $\mathrm{C}_{\mathrm{S2}^{+}}$are mass concentrations for glucose and ammonium, respectively, $\mathrm{K}_{\mathrm{B} / \mathrm{S} 1}$ and $\mathrm{K}_{\mathrm{B} / \mathrm{S} 2^{+}}$are saturation constants for biomass growth by consumption of glucose and ammonium.

Biomass generation in the flowing water phase is considered a dynamic balance of various mass exchange processes including bacterial growth, retention, and detachment:

$$
R_{B}=R_{B f}-R_{t}+R_{d}
$$

where, $R_{\mathrm{r}}$ and $\mathrm{R}_{d}$ are biomass retention and detachment rates, described in Eqs (6.6) and (6.7); and $\mathrm{R}_{\mathrm{Bf}}$ is the growth rate for bacterial cells in the flowing phase [Bu'lock and Kristiansen, 1984]:

$$
R_{B f}=u_{m, B} \frac{C_{S 1}}{K_{B / S 1}+C_{S 1}} \frac{C_{S 2^{+}}}{K_{B / S 2^{+}}+C_{S 2^{+}}} C_{B}
$$

here, $C_{B}$ is the concentration of bacterial cells in the flowing phase.

The production rate for acetate, carbon dioxide, and nitrogen are respectively given [Bajpai and Reuss, 1982]: 


$$
\begin{aligned}
& \mathbf{R}_{\mathrm{A}}= \begin{cases}0, & \text { if } \mathrm{C}_{\mathrm{S} 1} \leq \mathrm{C}_{\mathrm{S} 1}^{*} \\
\mu_{\mathrm{mA}} \frac{\mathrm{C}_{\mathrm{S} 1}-\mathrm{C}_{\mathrm{S} 1}^{*}}{\mathrm{~K}_{\mathrm{A} / \mathrm{S} 1}+\mathrm{C}_{\mathrm{S} 1}-\mathrm{C}_{\mathrm{S} 1}^{*}}\left(\mathrm{C}_{\mathrm{B}}+\sigma \rho_{\mathrm{B}}\right), \text { if } \mathrm{C}_{\mathrm{S} 1}>\mathrm{C}_{\mathrm{S} 1}^{*}\end{cases} \\
& \mathbf{R}_{\mathrm{N}}= \begin{cases}0, & \text { if } \mathrm{C}_{\mathrm{S} 2} \leq \mathrm{C}_{\mathrm{S} 2}^{*} \\
\mu_{\mathrm{mN}} \frac{\mathrm{C}_{\mathrm{S} 2^{-}}-\mathrm{C}_{\mathrm{S} 2}^{*}}{\mathrm{~K}_{\mathrm{N} / 2^{-}}+\mathrm{C}_{\mathrm{S} 2^{-}}-\mathrm{C}_{\mathrm{S} 2}^{*}}\left(C_{\mathrm{B}}+\sigma \rho_{\mathrm{B}}\right), & \text { if } \mathrm{C}_{\mathrm{S} 2^{-}}>\mathrm{C}_{\mathrm{S} 2}^{*}\end{cases}
\end{aligned}
$$

where, $R_{A}$ and $R_{N}$ are production rates for acetate and nitrogen, respectively; $\mu_{m A}$ and $\mu_{\mathrm{mN}}$ are respectively maximum specific production rates for acetate and nitrogen; $\mathrm{K}_{\mathrm{A} / \mathrm{S} 1}$ is the saturation constant for production of acetate by consumption of glucose; $\mathrm{K}_{\mathrm{N} / \mathrm{S} 2^{-}}$is the saturation constant for net production of nitrogen by consumption of nitrate, $\mathrm{C}_{\mathrm{S} 1}^{*}$ and $\mathrm{C}_{\mathrm{S} 2}^{*}$ are critical concentrations of glucose and ammonium nitrate, respectively. The production rate of $\mathrm{CO}_{2}$ is proportional to that of acetate:

$$
R_{C}=\omega R_{A}
$$

A typical substrate consumption equation can be used to describe the utilization of glucose and ammonium nitrate [Bu'lock and Kristiansen, 1984]:

$$
\begin{aligned}
& R_{S 1}=-\frac{1}{Y_{B / S 1}}\left(R_{B f}+R_{B s}\right) \\
& R_{S 2^{+}}=-\frac{1}{Y_{B / S 2^{+}}}\left(R_{B f}+R_{B s}\right)
\end{aligned}
$$




$$
R_{S 22^{-}}=-\frac{1}{Y_{N / S 2^{-}}} R_{N}
$$

where, $R_{S 1}, R_{S^{+}}$, and $R_{S^{2}-}$ are consumption rates of glucose, ammonium, and nitrate, respectively; $Y_{B / S 1}$ and $Y_{A / S 1}$, are yield coefficients for biomass and acetate per unit glucose, $Y_{\mathrm{B} / \mathrm{S2^{+ }}}$ and $\mathrm{Y}_{\mathrm{N} / \mathrm{S2} 2^{-}}$are yield coefficients for biomass per unit ammonium and nitrogen per unit nitrate, respectively; and $m_{\mathrm{S} 1}$ and $m_{\mathrm{S} 2}$ are coefficients for energy maintenance by consumption of glucose and ammonium nitrate, respectively.

\section{Multiphase-Flow Equations}

After significant microbial plugging and biogenic gas production, the simultaneous flow of oil, water, and gas phases can occur in the porous medium during continued-injection. A three-phase transport model should be developed to describe this process.

Consider linear horizontal flow. If capillary pressure is neglected, and the gas is assumed to dissolve in both oil and water phases, a complete set of equations for pressure and saturations along the one-dimensional core system can be derived after an appropriate arrangement [Fanchi, et al., 1982]:

$$
\begin{aligned}
& \phi C_{1} \frac{\partial p}{\partial t}=\beta_{0} \frac{\partial}{\partial x}\left(\psi_{0} \frac{\partial p}{\partial x}\right)+\beta_{w} \frac{\partial}{\partial x}\left(\psi_{w} \frac{\partial p}{\partial x}\right)+\beta_{g}\left[\frac{\partial}{\partial x}\left(\psi_{g} \frac{\partial}{\partial x}\right)+q_{g}\right] \\
&+\phi \frac{\partial \sigma}{\partial t} \\
& \frac{\partial}{\partial t}\left(\phi \frac{S_{0}}{B_{0}}\right)=\frac{\partial}{\partial x}\left(\psi_{0} \frac{\partial p}{\partial x}\right)
\end{aligned}
$$




$$
\begin{aligned}
& \frac{\partial}{\partial t}\left(\phi \frac{S_{w}}{B_{w}}\right)=\frac{\partial}{\partial x}\left(\psi_{w} \frac{\partial p}{\partial x}\right) \\
& \frac{\partial}{\partial t}\left[\phi\left(\frac{S_{g}}{B_{g}}+\frac{R_{s o} S_{o}}{B_{o}}+\frac{R_{s w} S_{w}}{B_{w}}\right)\right]=\frac{\partial}{\partial x}\left(\psi_{g} \frac{\partial p}{\partial x}\right)+q_{g}
\end{aligned}
$$

where:

$$
\begin{aligned}
& \beta_{0}=B_{0}-R_{s o} B_{g}, \quad \beta_{w}=B_{w}-R_{s w} B_{g}, \quad \beta_{g}=B_{g} \\
& \psi_{0}=\frac{K \lambda_{0}}{B_{o}}, \quad \psi_{w}=\frac{K \lambda_{w}}{B_{w}}, \psi_{g}=K\left(\frac{\lambda_{g}}{B_{g}}+\frac{R_{s o} \lambda_{o}}{B_{o}}+\frac{R_{s w} \lambda_{w}}{B_{w}}\right) \\
& \lambda_{0}=\frac{K_{r o}}{\mu_{0}}, \quad \lambda_{w}=\frac{K_{T w}}{\mu_{w}}, \quad \lambda_{g}=\frac{K_{r g}}{\mu_{g}} \\
& q_{g}=\frac{1}{\rho_{C S}} \frac{\partial C_{C}}{\partial t}+\frac{1}{\rho_{N S}} \frac{\partial C_{N}}{\partial t} \\
& C_{t}=C_{0} S_{o}+C_{w} S_{w}+C_{g} S_{g} \\
& C_{0}=-\frac{1}{B_{0}} \frac{\partial B_{0}}{\partial p}+\frac{B_{g}}{B_{0}} \frac{\partial R_{s o}}{\partial p} \\
& C_{w}=-\frac{1}{B_{w}} \frac{\partial B_{w}}{\partial p}+\frac{B_{g}}{B_{w}} \frac{\partial R_{s w}}{\partial p}
\end{aligned}
$$




$$
\begin{aligned}
& C_{g}=-\frac{1}{B_{g}} \frac{\partial B_{g}}{\partial p} \\
& \phi=\phi_{0}(1-\sigma), \quad K=K_{0}\left(\frac{\phi}{\phi_{0}}\right)^{3} \\
& S_{o}+S_{w}+S_{g}+\sigma=1
\end{aligned}
$$

where, $p$ is pressure; $S_{0}, S_{w}$, and $S_{g}$ are saturations for oil, water, and gas respectiveiy; $\mathrm{B}_{0}, \mathrm{~B}_{\mathrm{w}}$, and $\mathrm{B}_{\mathrm{g}}$ are respectively formation volume factors for oil, water, and gas; $\mathrm{K}_{\mathrm{ro}}$, $\mathrm{K}_{\mathrm{rw}}$, and $\mathrm{K}_{\mathrm{rg}}$, are relative permeabilities to oil, water, and gas; $\mu_{0}, \mu_{\mathrm{w}}$, and $\mu_{\mathrm{g}}$ are viscosities for oil, water, and gas; $C_{t}$ is total compressibility, $C_{0}, C_{w}$, and $C_{g}$ are compressibilities for oil, water, and gas phases, respectively, $q_{R}$ is the total gas production (including $\mathrm{CO}_{2}$ and $\mathrm{N}_{2}$ ) generated as a result of metabolism; $\rho_{\mathrm{CS}}$ and $\rho_{\mathrm{NS}}$ are respectively densities of $\mathrm{CO}_{2}$ and $\mathrm{N}_{2}$ at standard conditions.

\subsection{Simplification and Specification}

Let $\mu_{\mathrm{ss}}$ be the specific growth rate for biomass in the two-substrate system:

$$
\mu_{\mathrm{ss}}=\mu_{\mathrm{m}, \mathrm{B}} \frac{\mathrm{C}_{\mathrm{S} 1}}{\mathrm{~K}_{\mathrm{B} / \mathrm{S} 1}+\mathrm{C}_{\mathrm{S} 1}} \frac{\mathrm{C}_{\mathrm{S} 2^{+}}}{\mathrm{K}_{\mathrm{B} / \mathrm{S} 2^{+}}+\mathrm{C}_{\mathrm{S} 2^{+}}}
$$

thus, the sessile biomass balanceequation (6.5) can be simplified:

$$
\frac{\partial \sigma}{\partial t}=K_{\mathrm{t}} \mathrm{u}_{\mathrm{f}} \mathrm{C}_{\mathrm{B}}(1-\sigma)-\mathrm{K}_{\mathrm{d}} \mathrm{u}_{\mathrm{f}} \mu_{\mathrm{w}} \frac{\sigma}{\mathrm{K}}+\mu_{\mathrm{ss}} \sigma
$$


since $\rho_{B}$ is a constant. If the injection flux, $u_{f}$, is specified, the species equation (6.3) can be rewritten:

$$
\frac{\partial C}{\partial t}=-\frac{u_{f}}{\phi} \frac{\partial C_{i}}{\partial x}+\frac{1}{\phi} \frac{\partial}{\partial x}\left(\phi K_{D} \frac{\partial C_{i}}{\partial x}\right)+\phi_{0} C_{i} \frac{\partial \sigma}{\partial t}+R_{i}
$$

In addition, further specifications can be made for the different mechanisms and flow patteris amung the injection, incubation, and continued-injection processes.

\section{Injection Process}

Since bacterial plugging and biogenic gas production appear insignificant during initial injection, the residual oil and biogenic gas are immobile. Thus, a single flowing water phase can be assumed during this process and the pressure equation can simply expressed by Darcy's equation:

$$
\frac{\partial p}{\partial x}=-u_{f} \frac{\mu_{w}}{K}
$$

where, $u_{f}$, the Darcy flux, is assurned to be a constant; $\mu_{w}$ is viscosity of the water phase; and $\mathrm{K}$ is the updated permeability.

In addition, since $n$ iroorganisms and nutrients are transported into the core system during an injection perion much shorter than incubation time, it is assumed that growth and metabolism occur only in the flowing phise during injection. Tisefore, growth, production, and consurnption rates by the sessil: bacterium phase during injection are neglected in the pertinent equations. A specifiel model with appropriate initial and boundary conditions is roposed for this process, as shown in the Table 6.1. 


\section{Incubation Process}

The sandstone core is "shut-in" to allow microbial growth and metabolism in this process. Since there is no flow, the rate-controlled retention and detachment terms disappear from $\mathrm{Eq}$ (6.33), and the convection terms are dropped from the convectiondispersion Eq (6.34). Although molecular diffusion for each species exists during incubation the molecular diffusion is much smaller compared with the species generation and consumption rates and is neglected. Under these conditions, the model is reduced to a set of zero-dimension equations applied to each grid block. Each block behaves like a single batch fermenter, with no mass exchange with adjacent blocks. This simplification offers the opportunity to increase time step sizes during the incubation computation. Pressure is assumed to be uniform along the core because no flow occurs in the core, and thus the pressure gradient terms in the pressure equation (6.18) are dropped. A simplified model for the incubation process is summarized in the Table 6.2.

\section{Continued-injection Process}

A major characteristic in this process is simultaneous flow of oil, water, and gas phases as a result of preferential microbial plugging and significant biogenic gas production. Although much of the gas may dissolve in the oil phase, some gas as a free phase may flow through " own channels in the core, particularly towards the outlet from the core. The rate-controlled retention and detachment of bacteria may become active again during the continued-injection. A general three-phase and sevenspecies model is summarized in Table 6.3. 


\subsection{Numerical Solutions}

The partial differential equations are solved by using the method of lines [Ames, 1977]. Spatial derivatives are approximated by their finite difference formulas while the temporal derivatives remain continuous, and the numerical solutions are carried out using the 1(2)-order Runge-Kutta-Fehlberg method.

The first-order spatial derivative corresponding to the convective transport for species $\mathrm{i}$ in Eq (6.34) is replaced by Leonard's [1984] third-order upwind formula which is resistant to numerical dispersion and oscillation:

$$
\left[\frac{\partial C_{i}}{\partial x}\right]_{j}=\frac{\left(C_{i}\right)_{j-2}-6\left(C_{i}\right)_{j-1}+3\left(C_{i}\right)_{j}+2\left(C_{i}\right)_{j+1}}{6 \Delta x}+\theta\left(\Delta x^{3}\right)
$$

Since the concentration $\left(C_{i}\right)_{0}$ required in Eq (6.36) does not exist, the first-order spatial derivative at $j=2$ is expressed by the two-point central weighting scheme:

$$
\left[\frac{\partial C_{i}}{\partial x}\right]_{2}=\frac{\left(C_{i}\right)_{3}-\left(C_{i}\right)_{1}}{2 \Delta x}+\theta\left(\Delta x^{2}\right)
$$

The dispersion term, a second-order spatial derivative, is approximated by the secondorder central finite difference scheme:

$$
\begin{aligned}
& {\left[\frac{\partial}{\partial x}\left(\phi K_{D} \frac{\partial C_{i}}{\partial x}\right)\right]_{j}=} \\
& \frac{\left(\phi K_{D}\right)_{j+1 / 2}\left[\left(C_{i}\right)_{j+1}-\left(C_{i}\right)_{j}\right]-\left(\phi K_{D}\right)_{j-1 / 2}\left[\left(C_{i}\right)_{j}-\left(C_{i}\right)_{j-1}\right]}{\Delta x^{2}}
\end{aligned}
$$

To approximate the second-order spatial derivatives in the pressure equation 
(6.18), a second-order central difference scheme is used:

$$
\left[\frac{\partial}{\partial x}\left(\psi_{1} \frac{\partial p}{\partial x}\right)\right]_{j}=\frac{\left(\psi_{1}\right)_{j+1 / 2}\left(p_{j+1}-p_{j}\right)-\left(\psi_{1}\right)_{j-1 / 2}\left(p_{j}-p_{j-1}\right)}{\Delta x^{2}}
$$

Consider an explicit algorithm to calculate saturations using a first-order approximation to $\mathrm{Eq}(6.19)$ and $(6.20)$, respectively:

$$
\begin{aligned}
& \frac{\left(\frac{\phi S_{o}}{B_{o}}\right)_{j}^{n+1}-\left(\frac{\phi S_{o}}{B_{o}}\right)_{j}^{n}}{\Delta t}=\left[\frac{\partial}{\partial x}\left(\psi_{o} \frac{\partial p}{\partial x}\right)\right]_{j}^{n+1} \\
& \frac{\left(\frac{\phi S_{w}}{B_{w}}\right)_{j}^{n+1}-\left(\frac{\phi S_{w}}{B_{w}}\right)_{j}^{n}}{\Delta t}=\left[\frac{\partial}{\partial x}\left(\psi_{w} \frac{\partial p}{\partial x}\right)\right]_{j}^{n+1}
\end{aligned}
$$

Through discretization in space and time, the model equations are transfered to a set of finite difference equations.

Since the incubation time is much longer than either the injertion or continued-injection times, the simulator efficiency greatly depends on the tine step sizes used in the incubation computation. Although bacterial cells grow at some exponential rate, growth, product formation, and substrate consumption rates decrease with time, and even become zero as the substrate is consumed. Hence, it is reasonable that the time step size be chosen to increase at an appropriate exponential rate during the incubation process.

Let $\Delta \mathrm{t}_{0}$ be an initial time step size, and $\theta$ a time-step-varying factor. Thus the time step size may increase in the following manner : 


$$
\Delta t_{n}=\theta \Delta t_{n-1}=\theta^{n-1} \Delta t_{0}
$$

\subsection{Application}

An experiment of static batch fermentation in an anaeorobic, nutrient-saturated, and unconsolidated porous media has been conducted. Growth of bacterial cells, along with production of acetate, $\mathrm{CO}_{2}$, and $\mathrm{N}_{2}$ by consumption of galactose and ammonium nitrate, has been observed. To simulate these microbial activities, the proposed model is reduced to a zero-dimension, batch-ferementer system as shown in Table 6.4. Yield coefficients are stoichiometrically estimated from chemical balance equations (Table 6.5). Other kinetic parameters are given in Table 6.8. Experimental results are presented in Table 6.7. Results from the simulator are shown in Table 6.8.

Comparison of simulation responses with experimental results are shown in Figures 6.1 to 6.5. A good match is achieved for galactose consumption (Figure 6.1) and acetate production (Figure 6.4). Biomass growth rate $\left(\mu_{\mathrm{B}}\right)$ (Figure 6.3) given by the simulator is lower than that from the experiment since growth lag-phase has not been considered in the model. Also presented are comparisons of consurnption of nitrate (Figure 6.2) and $\mathrm{N}_{2}$ production (Figure 6.5) between simulated and experimental results.

From chemical balance equations (Table 6.5), consumption of one-mole galactose should result in production of two-mole acetate, and two-mole nitrate should be reduced to one-mole $\mathrm{N}_{2}$. The results from the simulator satisfy the mass-balance criteria above. 


\subsection{Conclusions}

(1) A three-phase, seven species, one-dimensional model of the microbial process is proposed.

(2) A chemical balance equation describing the microbial process is used if which glucose and nitrate serve as nutrients and acetate, carbon dioxide, nitrogen and biomass are products.

(3) The model addresses three different mechanism and flow pattern catagories: initial injection, incubation, and continued injection. Material balance and multiphase flow equations are proposed for each of the catagories.

(4) A third order upwinding convective differencing scheme is adopted as a solution technique. This technique is highly resistant to numerical dispersion and oscillation.

(5) The model is successfully simplified to one-phase to simulate batch fermentation. 


\section{REFERENCES}

Ames, W.F. (1977). Numerical Methods for Partial Differential Equations, 2nd ed., Academic Press, New York.

Bajpai, R.K. and M. Reuss. 1982. Coupling of mixing and microbial kinetic for evaluating the performance of bioreactors, Can. J. Chem. Eng., 60, 384-392.

Breston, J.N. 1957. Selective plugging of waterflood input wells: theory, methds and resulis, J. Pet. Tech. (Mar. 1957) 26-31.

Bu'lock, J. and B. Kristiansen. 1984. Basic Biotechnology New York, 75-131.

Cernansky, A. and R. Siroky. 1985. Deep-bed filtration on filament layers of particles polydispersed in liquids, International Chemical Engineering, 25(2), 364-375.

Fanchi, J.R., K.J. Harpole, and S.W. Bujnowski. 1982. BOAST: A Three-Dimensional, Three-Phase Black Oil Applied Simulation Tool (Version 1.1), Vol.1: Technical Description and Fortran Code, Dept. of Energy DOE/BC/10033-3, USDOE Technical Information Center, Oak Ridge, Tennessee, 1-17.

Jang, L.K., M.M. Sharma, and T.F. Yen. 1984. The transport of bacteria in porous media and its significance in microbial enhanced oil recovery, Paper SPE 12770 presented at the 1984 California Regional Meeting, Long Beach, CA, (Apr. 1984) 1113.

Jenneman, G.E., M.J. McInerney and R.M. Knapp. 1985. Microbial penetration through nutrient-saturated berea sandstone, Appl. Environ. Microbiol., 50, 383-391.

Jenneman, G.E., R.M. Knapp, M.J. McInerney, D.E. Menzie and D.E. Revus. 1984. Experimental studies of in situ microbial enhanced oil recovery, Soc. Pet. Eng. J., 24, 33-37.

Knapp, R.M., F. Civan, and M.J. McInerney. 1988. Modeling growth and transport of microorganisms in porous formations, IMACS, Proceedings of 12th World Congress on Scientific Computation, July 18-22, 1988, Paris, France, Edited by R. Vichnevetsky, P.Borne, and J. Vignes, Vol. 3, 676-679.

Leonard, B.P. 1984. Third-order upwinding as a rational basis for computational fluid dynamics, Computational Techniques and Applications: CTAC-83, Editors, J. Noye and C. Fletcher, 106-120. 
Table 6.1 Model Equations for Injection Process

\begin{tabular}{|c|c|}
\hline Types & Equations \\
\hline Species & $\begin{array}{l}\frac{\partial C_{i}}{\partial t}=-\frac{u_{I}}{\phi} \frac{\partial C_{i}}{\partial x}+\frac{1}{\phi} \frac{\partial}{\partial x}\left(\phi K_{D} \frac{\partial C_{i}}{\partial x}\right)+\phi_{0} C_{i} \frac{\partial \sigma}{\partial t}+R_{i} \\
\frac{\partial C_{C}}{\partial t}=\omega \frac{\partial C_{N}}{\partial t}, \quad \text { or } \quad C_{C}=\omega C_{A} \\
\text { where, } i=A, B, N, S 1, S 2^{+}, S 2^{-}\end{array}$ \\
\hline Sessile & $\frac{\partial \sigma}{\partial t}=K_{r} u_{f} C_{B}(1-\sigma)-K_{d} \sigma u_{f} \frac{\mu_{w}}{K}$ \\
\hline Pressure & $\frac{\partial p}{\partial x}=-u_{f} \frac{\mu_{w}}{K}$ \\
\hline I.C. & $\left(C_{i}\right)_{t=0}=C_{i}^{0}, \quad(\sigma)_{t=0}=\sigma^{0}, \quad(p)_{t=0}=p^{0}$ \\
\hline B.C. & $\begin{array}{l}{\left[u_{i} C_{i}-\phi K_{V} \frac{\partial C_{i}}{\partial x}\right]_{x=0}=u_{I}\left(C_{i}\right)_{\text {inlet }}, \quad\left[\frac{\partial C_{i}}{\partial x}\right]_{x=L}=0} \\
(p)_{x=0}=p_{\text {inj }}\end{array}$ \\
\hline
\end{tabular}

I.C. - Initial Conditions

B.C. - Boundary Conditions 


\section{'Table 6.2 Model Equations for Incubation Process}

\begin{tabular}{|c|c|}
\hline Types & Equations \\
\hline Species & $\begin{array}{l}\frac{\partial C_{i}}{\partial t}=\phi_{0} C_{i} \frac{\partial \sigma}{\partial t}+R_{i} \\
\frac{\partial C_{C}}{\partial t}=\omega \frac{\partial C_{A}}{\partial t}, \quad \text { or } C_{C}=\omega C_{A} \\
\text { where, } i=A, B, N, S 1, S^{+}, S 2^{-}\end{array}$ \\
\hline Sessile & $\frac{\partial \sigma}{\partial t}=\mu_{s s} \sigma$ \\
\hline Pressure & $\phi C_{t} \frac{\partial p}{\partial t}=B_{g}\left(\frac{1}{\rho_{C S}} \frac{\partial C_{C}}{\partial t}+\frac{1}{\rho_{N S}} \frac{\partial C_{N}}{\partial t}\right)+\phi \frac{\partial \sigma}{\partial t}$ \\
\hline 1.C. & $\left(C_{i}\right)_{t=T}=\left(C_{i}\right)^{s}, \quad(\sigma)_{t=T_{d}}=(\sigma)^{s}, \quad(p)_{t=T,}=(p)^{s}$ \\
\hline
\end{tabular}

I.C. - Initial Conditions 


\section{Table 6.3 Model Equations for Continued-injection Process}

\begin{tabular}{|c|c|}
\hline Types & Equations \\
\hline Species & $\begin{array}{l}\frac{\partial C_{i}}{\partial t}=-\frac{u_{f}}{\phi} \frac{\partial C_{i}}{\partial x}+\frac{1}{\phi} \frac{\partial}{\partial x}\left(\phi K_{D} \frac{\partial C_{i}}{\partial x}\right)+\phi_{0} C_{i} \frac{\partial \sigma}{\partial t}+R_{i} \\
\frac{\partial C_{C}}{\partial t}=\omega \frac{\partial C_{A}}{\partial t}, \quad \text { or } \quad C_{C}=\omega C_{A} \\
\text { where, } i=A, B, N, S 1, S^{+}, S 2^{-}\end{array}$ \\
\hline Sessile & $\frac{\partial \sigma}{\partial t}=K_{r} u_{l} C_{l B}(1-\sigma)-K_{d} \sigma u_{r} \frac{\mu_{w}}{K}$ \\
\hline Pressure & $\begin{aligned} \phi C_{1} \frac{\partial p}{\partial t}= & \beta_{0} \frac{\partial}{\partial x}\left(\psi_{0} \frac{\partial p}{\partial x}\right)+\beta_{w} \frac{\partial}{\partial x}\left(\psi_{w} \frac{\partial p}{\partial x}\right)+\beta_{g}\left[\frac{\partial}{\partial x}\left(\psi_{g} \frac{\partial p}{\partial x}\right)+c_{b} l\right. \\
& +\phi \frac{\partial \sigma}{\partial t}\end{aligned}$ \\
\hline Saturations & $\begin{array}{l}\frac{\partial}{\partial t}\left(\phi \frac{S_{0}}{B_{0}}\right)=\frac{\partial}{\partial x}\left(\psi_{0} \frac{\partial p}{\partial x}\right), \quad \frac{\partial}{\partial t}\left(\phi \frac{S_{w}}{B_{w}}\right)=\frac{\partial}{\partial x}\left(\psi_{w} \frac{\partial p}{\partial x}\right) \\
\frac{\partial}{\partial t}\left[\phi\left(\frac{S_{g}}{B_{g}}+\frac{R_{s o} S_{o}}{B_{o}}+\frac{R_{s w} S_{w}}{B_{w}}\right)\right]=\frac{\partial}{\partial x}\left(\psi_{B} \frac{\partial p}{\partial x}\right)+q_{g}\end{array}$ \\
\hline I.C. & $\begin{array}{ll}\left(C_{i}\right)_{l=T_{w}}=i^{*}, \quad(\sigma)_{t=T_{w}}=\sigma^{w}, \quad(p)_{t=T_{w}}=p^{w} \\
\left(S_{j}\right)_{l=T_{w}}=S_{j}^{w}, \quad j=0, w, g\end{array}$ \\
\hline B.C. & $\begin{array}{l}\left(u_{1} C_{i}-\phi K_{D} \frac{\partial C_{i}}{\partial x}\right]_{x=0}=u_{N}\left(C_{i}\right)_{\text {inict }}, \quad\left[\frac{\partial C_{i}}{\partial x}\right]_{x=L}=0 \\
(p)_{x=0}=p_{\text {inlet }}\end{array}$ \\
\hline
\end{tabular}

I.C. - Initial Condition.s

B.C. - Boundary Conditions 


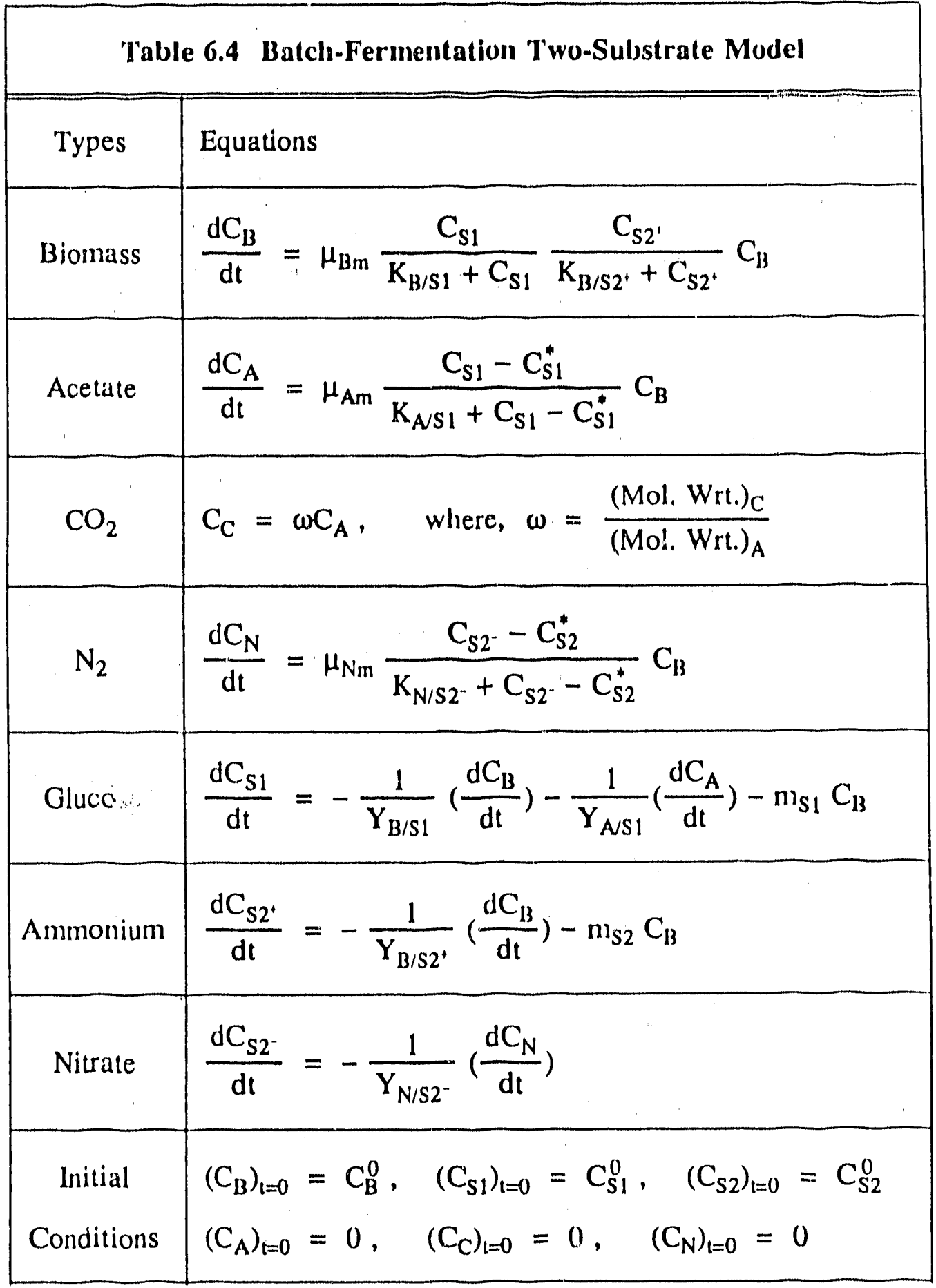




\section{Table 6.5 Stoichiometric Parameters}

\begin{tabular}{|c|c|}
\hline $\begin{array}{l}\text { Chemical } \\
\text { Balance }\end{array}$ & $\begin{array}{l}\mathrm{C}_{6} \mathrm{H}_{12} \mathrm{O}_{6} \rightarrow 2 \mathrm{CH}_{3} \mathrm{COO}^{-}+2 \mathrm{CO}_{2} \\
2 \mathrm{NO}_{3}^{-} \rightarrow \mathrm{N}_{2} \\
\mathrm{C}_{6} \mathrm{H}_{12} \mathrm{O}_{6}+1.2 \mathrm{NH}_{4}^{+} \rightarrow 6 \mathrm{CH}_{1.8} \mathrm{O}_{0.5} \mathrm{~N}_{0.2}\end{array}$ \\
\hline $\begin{array}{l}\text { Molccular } \\
\text { Wcight }\end{array}$ & $\begin{array}{l}\mathrm{C}_{6} \mathrm{H}_{12} \mathrm{O}_{6}(\text { galactose }-\mathrm{S} 1)=180.156 \\
\mathrm{NH}_{4}^{+}\left(\text {ammonium }-\mathrm{S}^{+}\right)=18.042 \\
\mathrm{NO}_{3}^{-}\left(\text {nitrate }-\mathrm{S2}^{-}\right)=62.01 \\
\mathrm{CH}_{3} \mathrm{COO}^{-}(\text {acctate }-\mathrm{A})=59.044 \\
\mathrm{CO}_{2}(\text { carbon dioxide }-\mathrm{C})=44.01 \\
\mathrm{~N}_{2}(\text { nitrogen }-\mathrm{N})=28.02 \\
\mathrm{CH}_{1.8} \mathrm{O}_{0.5} \mathrm{~N}_{0.2}(\text { biomass }-\mathrm{B})=24.6264\end{array}$ \\
\hline Coefficicnls & $\begin{array}{l}Y_{B / S 1}=\frac{6 \times 24.6264}{1 \times 180.156}=0.8202 \\
Y_{B / S 2^{+}}=\frac{6 \times 24.6264}{1.2 \times 18.042}=6.8247 \\
Y_{N S 1}=\frac{2 \times 59.044}{1 \times 180.156}=0.6555 \\
Y_{N / S 2^{-}}=\frac{1 \times 28.02}{2 \times 62.01}=0.2259\end{array}$ \\
\hline
\end{tabular}


Table 6.6 Kinetic Parameters for Batch Fermentation

\begin{tabular}{|c|c|c|c|c|}
\hline Symbols & Definitions & Values & Units & $\begin{array}{l}\text { Source } \\
\text { Comments }\end{array}$ \\
\hline$\mu_{R_{m}}$ & max specific growth rate for biomass & 0.602 & $1 / \mathrm{mr}$ & (1) \\
\hline$\mu_{\mathrm{Am}}$ & max specific production rate for acetate & 3.35 & $1 / \mathrm{hr}$ & estimated" \\
\hline$\mu_{\mathrm{Nm}}$ & $\max$ specific production rate for $\mathrm{N}_{2}$ & 1.21 & $1 / \mathrm{hr}$ & estimated" \\
\hline $\mathrm{K}_{\mathrm{B} / \mathrm{S} 1}$ & saturation const for biomass on galactose & 1.345 & $\mathrm{mg} / \mathrm{cm}^{3}$ & estimated $^{*}$ \\
\hline $\mathrm{K}_{\mathrm{B} / \mathrm{S} 2^{+}}$ & saturation const for biomass on $\mathrm{NH}_{4}^{+}$ & 1.234 & $\mathrm{mg} / \mathrm{cm}^{3}$ & estimated ${ }^{*}$ \\
\hline $\mathbf{K}_{\boldsymbol{N} \mathbf{S 1}}$ & saturation const for acetate on galactose & 0.01 & $\mathrm{mg} / \mathrm{cm}^{3}$ & estimated" \\
\hline $\mathrm{K}_{\text {Ns } 2^{-}}$ & saturation const for $\mathrm{N}_{2}$ on $\mathrm{NO}_{3}^{-}$ & 0.01 & $\mathrm{mg} / \mathrm{cm}^{3}$ & estimated ${ }^{*}$ \\
\hline $\mathrm{c}_{\mathrm{s} 1}^{*}$ & critical concentration for galactose & 0.03 & $\mathrm{mg} / \mathrm{cm}^{3}$ & (2) \\
\hline$C_{s z}^{*}$ & critical concentration for $\mathrm{NO}_{3}^{-}$ & 0.03 & $\mathrm{mg} / \mathrm{cm}^{3}$ & (2) \\
\hline $\mathrm{m}_{\mathrm{s} 1}$ & coeff of energy maintenance by galactose & 0.0001 & $\mathrm{mg} / \mathrm{mg} \cdot \mathrm{hr}$ & estimated ${ }^{\circ}$ \\
\hline $\mathrm{m}_{\mathrm{s} 2-}$ & coeff of energy maintenance by $\mathrm{NO}_{3}^{-}$ & 0.0001 & $\mathrm{mg} / \mathrm{mg} \cdot \mathrm{hr}$ & estimated" \\
\hline
\end{tabular}

"by trial and error

(1) Measured in batch growth experiment

(2) Bajpai and Reuss, 1982 
Table 6.7 Experiment Results from Batch Fermentation

\begin{tabular}{|c|c|c|c|c|c|c|}
\hline \hline $\begin{array}{c}\text { Time } \\
(\mathrm{hr})\end{array}$ & $\begin{array}{c}\text { Galactose } \\
(\mathrm{mM})\end{array}$ & $\begin{array}{c}\text { Nitrate } \\
(\mathrm{mM})\end{array}$ & $\begin{array}{c}\text { Biomass } \\
\left(\text { cells } / \mathrm{cm}^{3}\right)\end{array}$ & $\begin{array}{c}\text { Acetate } \\
(\mathrm{mM})\end{array}$ & $\begin{array}{c}\mathrm{CO}_{2} \\
(\mathrm{mM})\end{array}$ & $\begin{array}{c}\mathrm{N}_{2} \\
(\mathrm{mM})\end{array}$ \\
\hline 00.0 & 26.6 & 35.3 & $2.94 \times 10^{4}$ & 0.00 & 0.00 & 0.00 \\
06.0 & 26.4 & 34.71 & $2.94 \times 10^{4}$ & 0.00 & 0.00 & 0.00 \\
10.5 & 26.3 & 34.91 & $1.33 \times 10^{5}$ & 0.00 & 0.00 & 0.00 \\
15.0 & 26.4 & 34.85 & $3.30 \times 10^{5}$ & 0.00 & 0.00 & 0.00 \\
20.0 & 26.5 & 34.9 & $4.10 \times 10^{6}$ & 0.00 & 0.00 & 0.00 \\
35.0 & 24.35 & 26.63 & $2.16 \times 10^{7}$ & 3.82 & 3.82 & 4.34 \\
41.5 & 21.8 & 24.06 & $2.16 \times 10^{7}$ & 7.41 & 7.41 & 5.62 \\
\hline
\end{tabular}

Table 6.8 Simulation Response to Batch Fermentation

\begin{tabular}{|c|c|c|c|c|c|c|}
\hline \hline $\begin{array}{c}\text { Time } \\
(\mathrm{hr})\end{array}$ & $\begin{array}{c}\text { Galactose } \\
(\mathrm{mM})\end{array}$ & $\begin{array}{c}\text { Nitrate } \\
(\mathrm{mM})\end{array}$ & $\begin{array}{c}\text { Biomass } \\
\left(\text { cells/ } \mathrm{cm}^{3}\right)\end{array}$ & $\begin{array}{c}\text { Acetate } \\
(\mathrm{mM})\end{array}$ & $\begin{array}{c}\mathrm{CO}_{2} \\
(\mathrm{mM})\end{array}$ & $\begin{array}{c}\mathrm{N}_{2} \\
(\mathrm{mM})\end{array}$ \\
\hline 00.0 & 26.6 & 35.3 & $2.94 \times 10^{4}$ & 0.00 & 0.00 & 0.00 \\
06.0 & 26.6 & 35.3 & $7.68 \times 10^{4}$ & 0.02 & 0.02 & 0.01 \\
10.5 & 26.6 & 35.2 & $1.58 \times 10^{5}$ & 0.04 & 0.04 & 0.03 \\
15.0 & 26.5 & 35.1 & $3.24 \times 10^{5}$ & 0.10 & 0.10 & 0.08 \\
20.0 & 26.5 & 34.9 & $7.26 \times 10^{5}$ & 0.23 & 0.23 & 0.18 \\
35.0 & 25.2 & 31.3 & $7.84 \times 10^{6}$ & 2.64 & 2.64 & 2.01 \\
41.5 & 22.8 & 24.0 & $2.16 \times 10^{7}$ & 7.40 & 7.40 & 5.61 \\
\hline
\end{tabular}




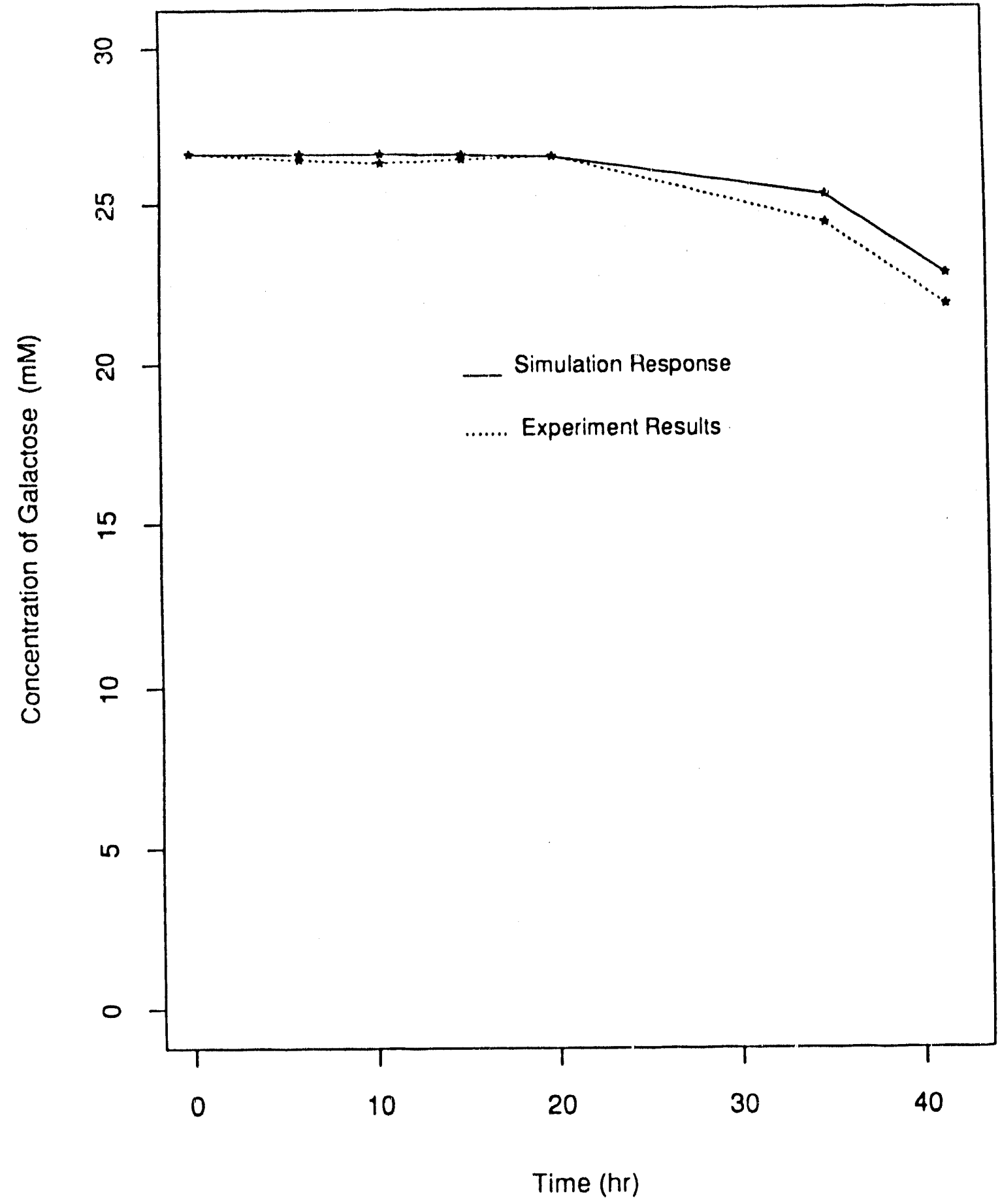

Figure 6.1: Consumption of Galactose during Batch Fermentation 


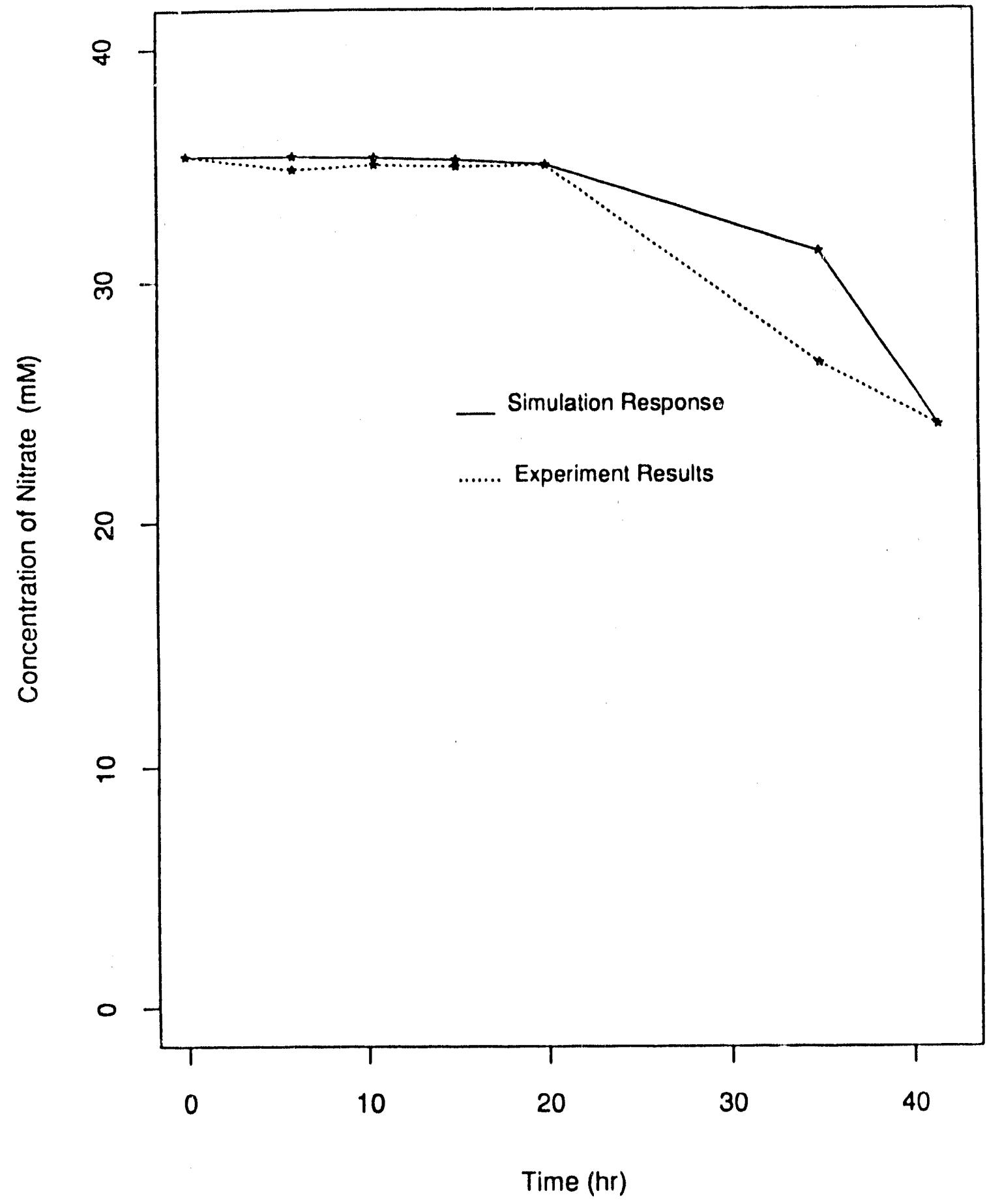

Figure 6.2: Consumption of Nitrate during Batch Fermentation 


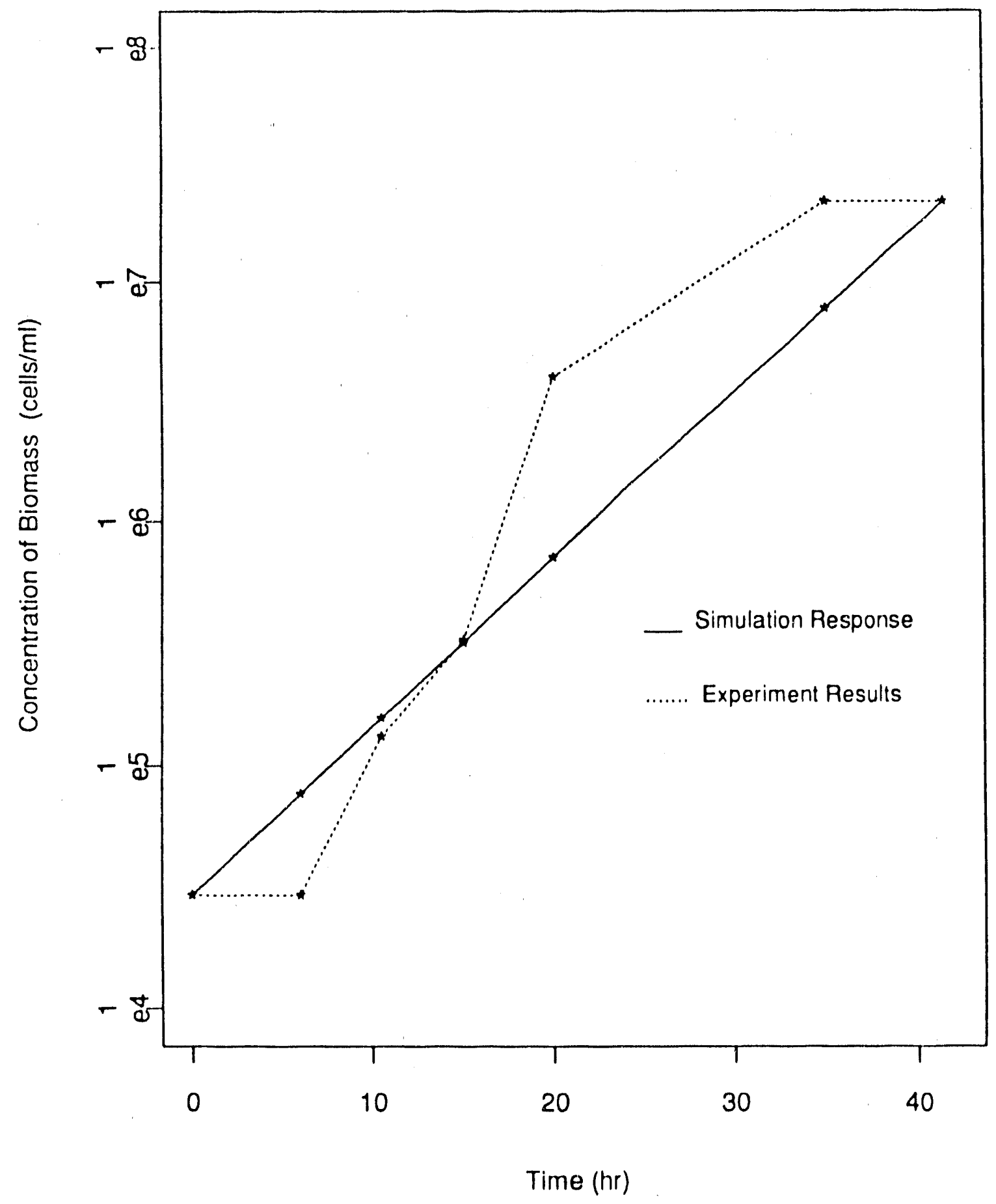

Figure 6.3: Growth of Biomass during Batch Fermentation 


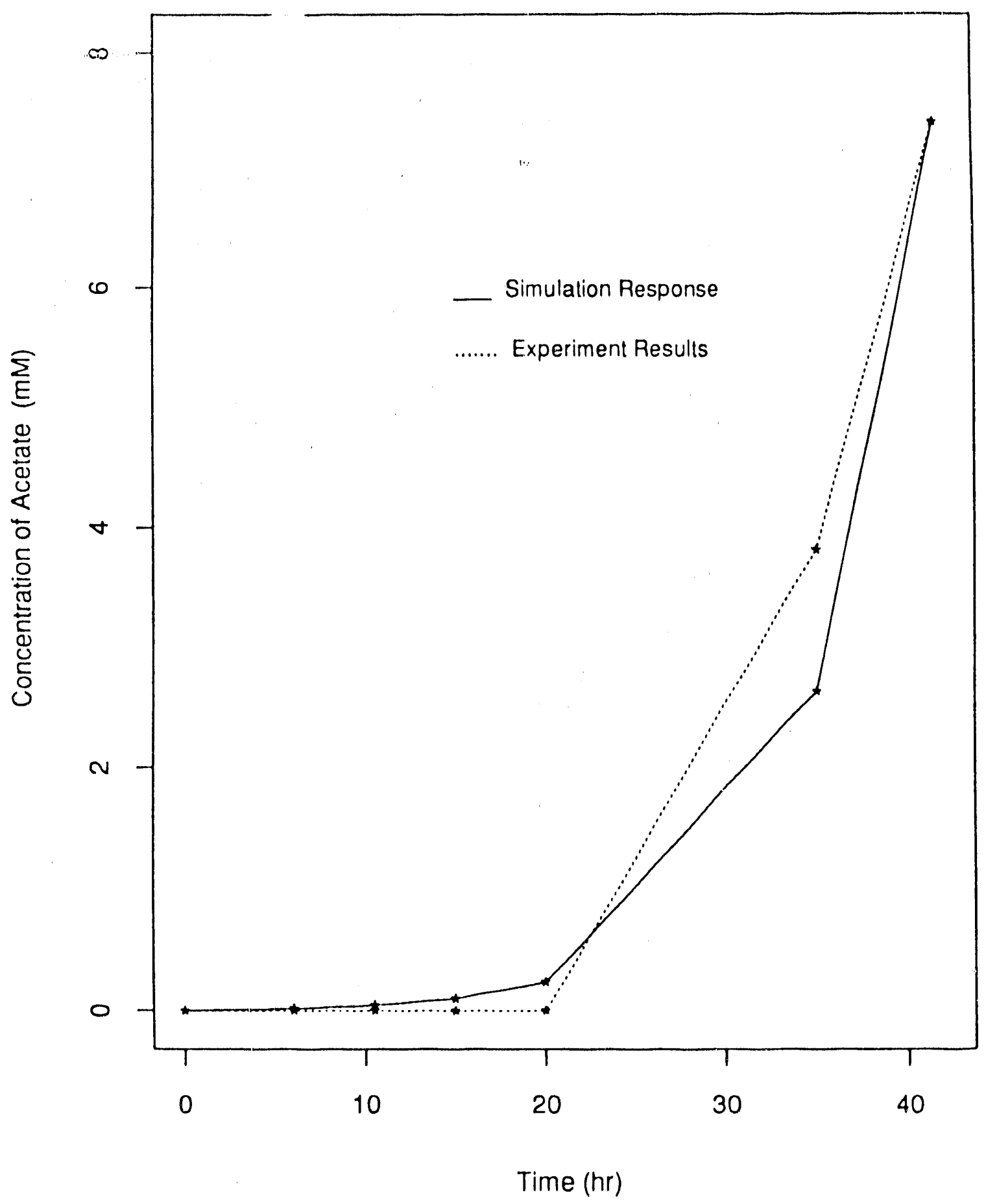

Figure 6.4: Production of Acetate during Batch Fermentation 


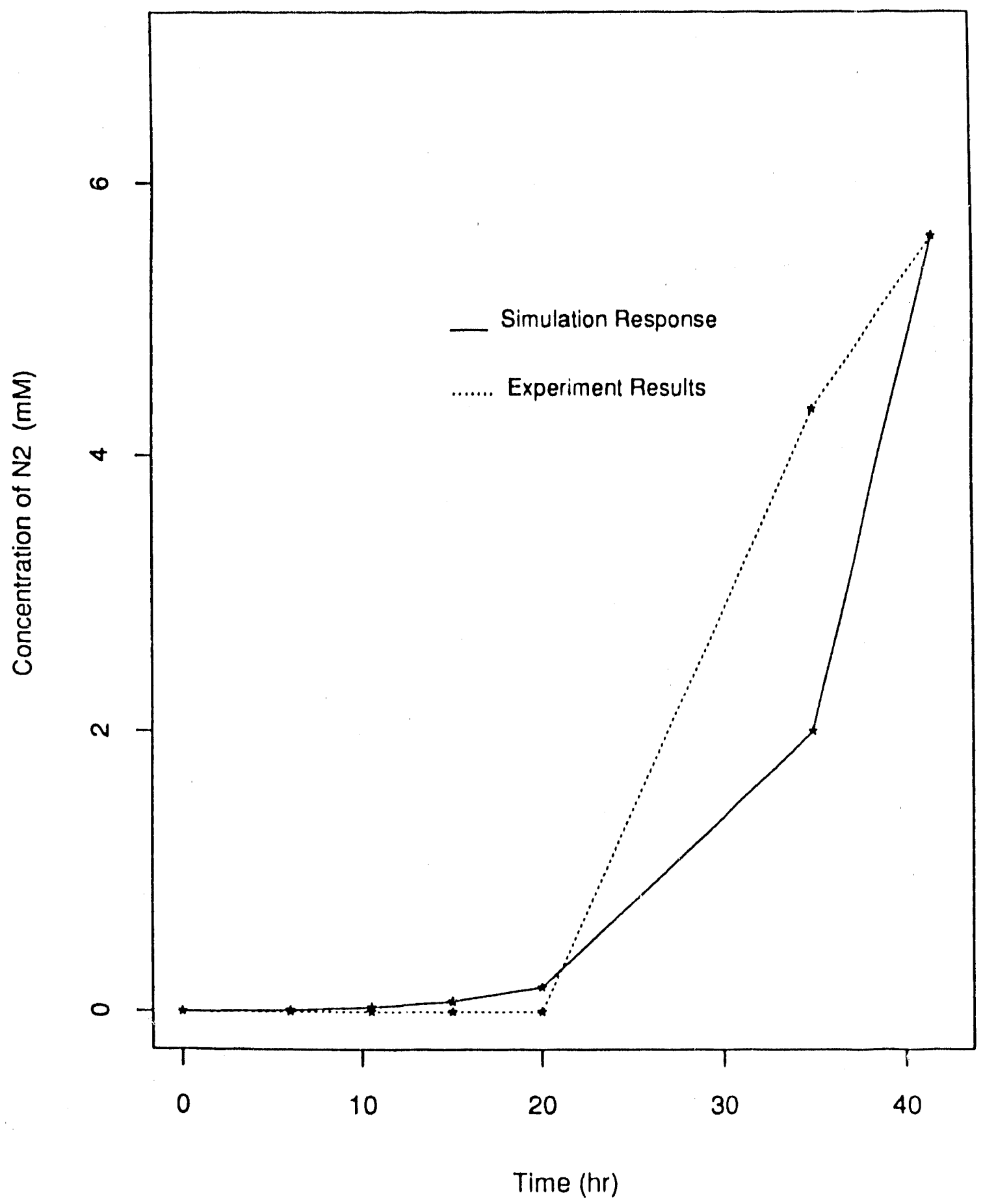

Figure 6.5: Production of N2 during Batch Fermentation 

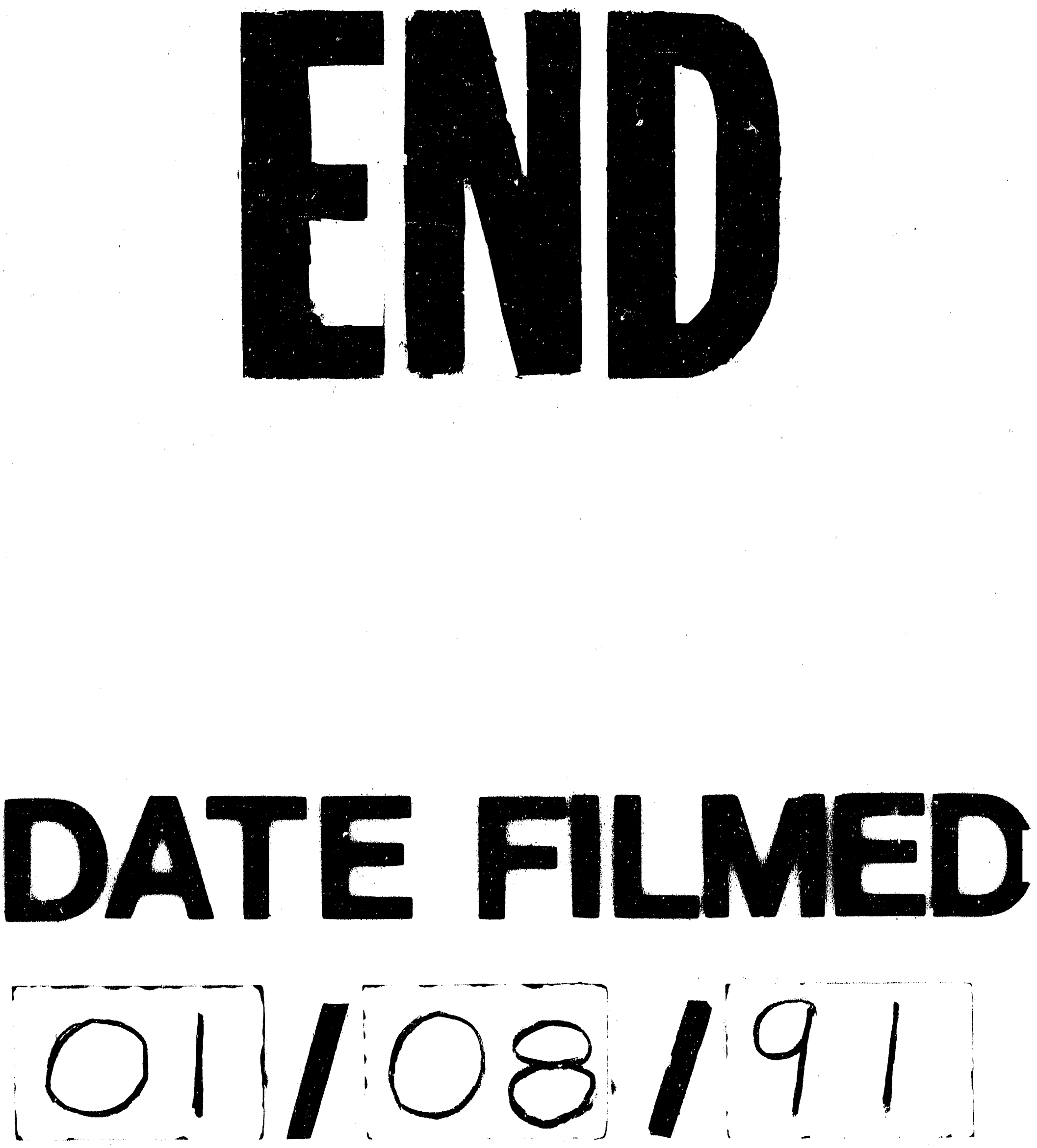
